\title{
SUMMARY OF THE OAHU, HAWAII, REGIONAL AQUIFER-SYSTEM ANALYSIS
}

\section{REGIONAL AQUTHER-SYSTIOM ANALYSTS}

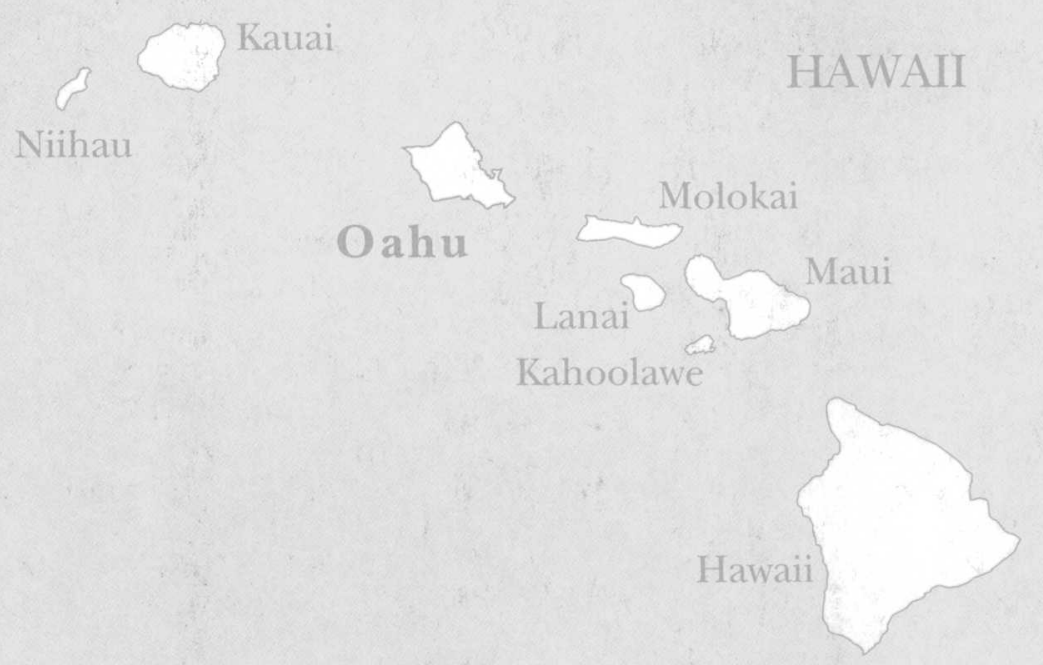

U.S. GEOLOGICAL SURVEY PROFESSIONAL PAPER 1412-A 


\section{AVAILABILITY OF BOOKS AND MAPS OF THE U.S. GEOLOGICAL SURVEY}

Instructions on ordering publications of the U.S. Geological Survey, along with prices of the last offerings, are given in the current-year issues of the monthly catalog "New Publications of the U.S. Geological Survey." Prices of available U.S. Geological Survey publications released prior to the current year are listed in the most recent annual "Price and Availability List." Publications that may be listed in various U.S. Geological Survey catalogs (see back inside cover) but not listed in the most recent annual "Price and Availability List" may no longer be available.

Order U.S. Geological Survey publications by mail or over the counter from the offices given below.

BY MAIL

\section{Books}

Professional Papers, Bulletins, Water-Supply Papers, Techniques of Water-Resources Investigations, Circulars, publications of general interest (such as leaflets, pamphlets, booklets), single copies of Preliminary Determination of Epicenters, and some miscellaneous reports, including some of the foregoing series that have gone out of print at the Superintendent of Documents, are obtainable by mail from

\section{U.S. Geological Survey, Information Services \\ Box 25286, Federal Center, Denver, CO 80225}

Subscriptions to Preliminary Determination of Epicenters) can be obtained ONLY from the

\section{Superintendent of Documents \\ Government Printing Office \\ Washington, D.C. 20402}

(Check or money order must be payable to Superintendent of Documents.)

\section{Maps}

For maps, address mail orders to

U.S. Geological Survey, Information Services Box 25286, Federal Center, Denver, CO 80225

\section{OVER THE COUNTER}

\section{Books and Maps}

Books and maps of the U.S. Geological Survey are available over the counter at the following U.S. Geological Survey Earth Science Information Centers (ESIC's), all of which are authorized agents of the Superintendent of Documents:

- ANCHORAGE, Alaska-Rm. 101, 4230 University Dr.

- LAKEWOOD, Colorado-Federal Center, Bldg. 810

- MENLO PARK, California-Bldg. 3, Rm. 3128, 345 Middlefield Rd.

- RESTON, Virginia-USGS National Center, Rm. 1C402, 12201 Sunrise Valley Dr.

- SALT LAKE CITY, Utah-Federal Bldg., Rm. 8105, 125 South State St.

-SPOKANE, Washington-U.S. Post Office Bldg., Rm. 135, West 904 Riverside Ave.

- WASHINGTON, D.C.-Main Interior Bldg., Rm. 2650, 18 th and C Sts., NW.

\section{Maps Only}

Maps may be purchased over the counter at the following U.S. Geological Survey offices:

- ROLLA, Missouri-1400 Independence Rd.

- STENNIS SPACE CENTER, Mississippi--Bldg. 3101 


\section{Summary of the Oahu, Hawaii, Regional Aquifer-System Analysis}

By WILLIAM D. NICHOLS, PATRICIA J. SHADE, and CHARLES D. HUNT, JR.

REGIONAL AQUIFER-SYSTEM ANALYSIS-OAHU, HAWAII

U.S. GEOLOGICAL SURVEY PROFESSIONAL PAPER 1412-A 


\title{
U.S. DEPARTMENT OF THE INTERIOR \\ BRUCE BABBITT, Secretary
}

\section{U.S. GEOLOGICAL SURVEY}

\author{
Gordon P. Eaton, Director
}

Any use of trade, product, or firm names in this publication is for descriptive purposes only and does not imply endorsement by the U.S. Government.

Library of Congress Cataloging in Publication Data

Nichols, William D.

Summary of the Oahu, Hawaii, regional aquifer-system analysis / by William D. Nichols, Patricia J. Shade and Charles D. Hunt, Jr.

p. cm. - (Regional aquifer-system analysis-Oahu, Hawaii) (U.S. Geological Survey Professional Paper ; 1412-A)

Includes bibliographical references.

Supt. of Docs. no. : I 19.16:1412-A

1. Aquifers-Hawaii-Oahu.

I. Shade, Patricia J. II. Hunt, Charles D. III. Title. IV. Series: U.S. Geological Survey Professional Paper ; 1412-A GB1199.3.H3N53 1996

$551.49^{\prime} 0969^{\prime} 3-\mathrm{dc} 20$

$96-32921$

CIP

For sale by the U.S. Geological Survey, Branch of Information Services, Box 25286, Federal Center, Denver, CO 80225

ISBN 0-607-86100-2 


\title{
FOREWORD
}

\author{
THE REGIONAL AQUIFER-SYSTEM ANALYSIS PROGRAM
}

The Regional Aquifer-System Analysis (RASA) Program was started in 1978 following a congressional mandate to develop quantitative appraisals of the major ground-water systems of the United States. The RASA Program represents a systematic effort to study a number of the Nation's most important aquifer systems, which in aggregate underlie much of the country and which represent an important component of the Nation's total water supply. In general, the boundaries of these studies are identified by the hydrologic extent of each system and accordingly transcend the political subdivisions to which investigations have often arbitrarily been limited in the past. The broad objective for each study is to assemble geologic, hydrologic, and geochemical information, to analyze and develop an understanding of the system, and to develop predictive capabilities that will contribute to the effective management of the system. The use of computer simulation is an important element of the RASA studies, both to develop an understanding of the natural, undisturbed hydrologic system and the changes brought about in it by human activities, and to provide a means of predicting the regional effects of future pumping or other stresses.

The final interpretive results of the RASA Program are presented in a series of U.S. Geological Survey Professional Papers that describe the geology, hydrology, and geochemistry of each regional aquifer system. Each study within the RASA Program is assigned a single Professional Paper number, and where the volume of interpretive material warrants, separate topical chapters that consider the principal elements of the investigation may be published. The series of RASA interpretive reports begins with Professional Paper 1400 and thereafter will continue in numerical sequence as the interpretive products of subsequent studies become available.

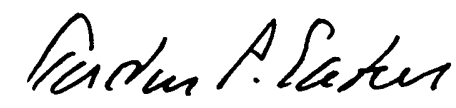

Gordon P. Eaton

Director 
. 


\section{CONTENTS}

\begin{tabular}{|c|c|}
\hline 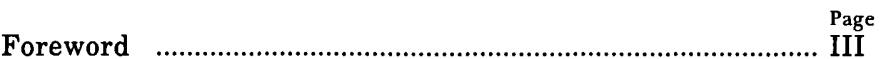 & \\
\hline (n) & \\
\hline Introduction & 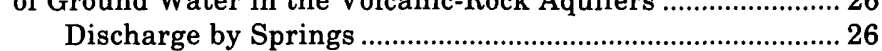 \\
\hline Purpose and Scope & 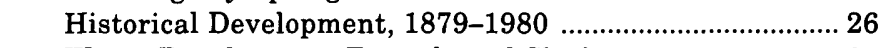 \\
\hline Study Area & Water-Development Tunnels and Shafts ........................ \\
\hline Physical Setting & Ground-Water Levels and Water-Level Trends ..................... 38 \\
\hline Climate & Southern Oahu \\
\hline Previous Studies & Earliest Measurements in Beretania, \\
\hline 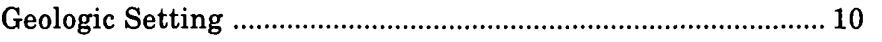 & Kalihi, and Moanalua Ground-Water Areas ............. 38 \\
\hline 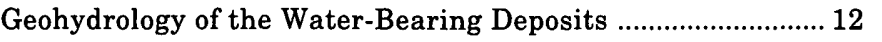 & Earliest Measurements in Pearl Harbor, \\
\hline 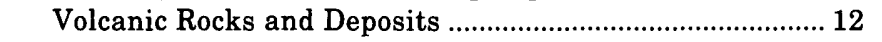 & Ewa, and Kaimuki Ground-Water Areas ................... 38 \\
\hline Lava Flows & Northern Oahu \\
\hline Dikes & Windward Oahu \\
\hline Pyroclastic Deposits & Southeastern Oahu \\
\hline Saprolite and Weathered Basalt ................................ 12 & Schofield Area \\
\hline Hydraulic Properties of the Volcanic Rocks .................. 13 & Water Budget and Ground-Water Recharge .............................. 40 \\
\hline 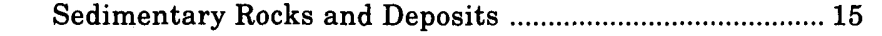 & Predevelopment Water Budget and \\
\hline Occurrence of Ground Water & Ground-Water Recharge \\
\hline Basal Ground Water & Effects of Land-Use Changes \\
\hline 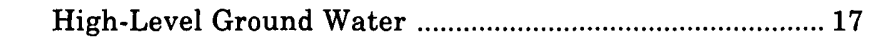 & Analysis of Ground-Water Flow in Southern Oahu .................. 45 \\
\hline Dike-Impounded Ground Water ..................................... 17 & 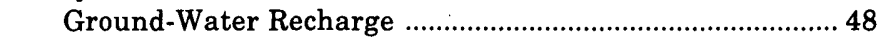 \\
\hline Perched Ground Water and Water & 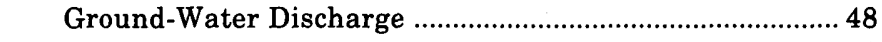 \\
\hline in the Unsaturated Zone & 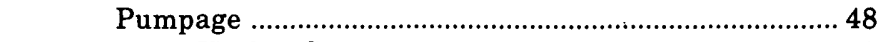 \\
\hline Schofield High-Level Ground Water ................................ 18 & 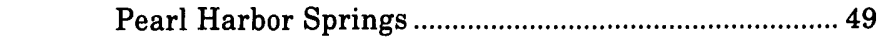 \\
\hline Saltwater & Southern Oahu Ground-Water Flow System .........................49 \\
\hline Aquifer System of Oahu & 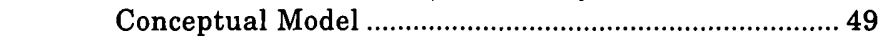 \\
\hline Principal Aquifers & Assumptions and Limitations for \\
\hline 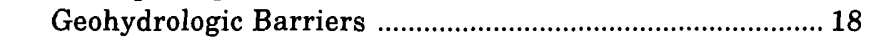 & 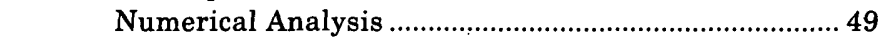 \\
\hline Ground-Water Areas of Oahu & Results \\
\hline 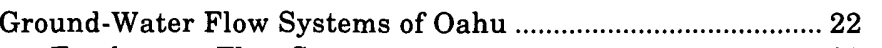 & 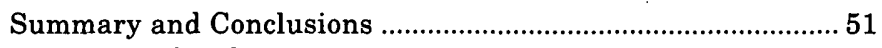 \\
\hline 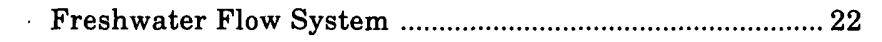 & References Cited \\
\hline Saltwater Flow System & Appendix \\
\hline
\end{tabular}

\section{ILLUSTRATIONS}

Figures 1-5. Maps showing:

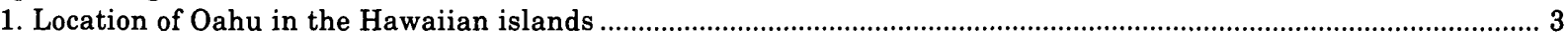

2. Topography and geographic features, island of Oahu

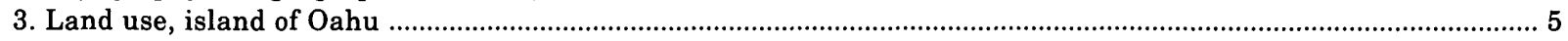

4. Generalized geology, island of Oahu, showing calderas of the Waianae and Koolau Volcanoes ............................... 6

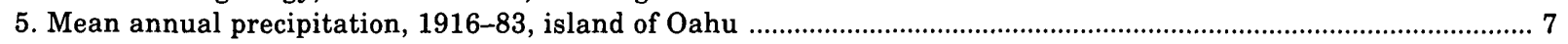

6. Graphs showing annual precipitation at selected stations, island of Oahu ................................................................... 8

7. Graphs showing mean monthly precipitation at selected stations, island of Oahu ....................................................... 9

8. Diagrammatic section showing modes of ground-water occurrence on the island of Oahu .............................................. 16

9-12. Maps showing:

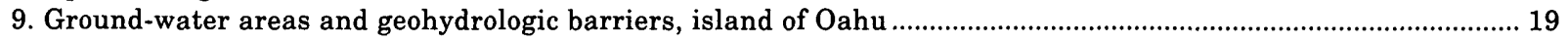

10. Ground-water areas and potentiometric surface (mid-1950's) in the principal volcanic aquifers,

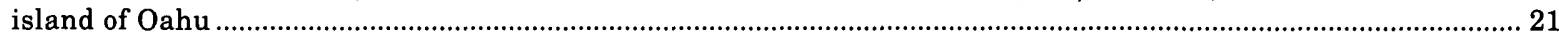

11. Freshwater flow systems, and the major areas of the central flow system, island of Oahu ................................23

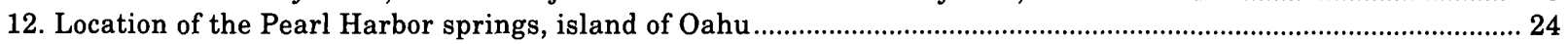




\section{ILLUSTRATIONS}

13-24. Graphs showing:

13. Water levels in well 187 open to freshwater and well 225 open to saltwater in the Pearl Harbor area, island of Oahu

14. Estimated mean daily discharge of the Pearl Harbor springs, island of Oahu, by decade, 1911-80

15. Number of wells, tunnels, and shafts drilled or constructed for irrigation water supply, island of Oahu

16. Number of wells, tunnels, and shafts drilled or constructed for public water supply, island of Oahu

17. Population of Honolulu and island of Oahu and the number of wells, tunnels, and shafts drilled or constructed for public water supply, 1890-1986

18. Wells, tunnels, and shafts drilled or constructed for ground-water development, island of Oahu, 1881-1985

19. Wells, tunnels, and shafts drilled or constructed for ground-water development in each ground-water flow system, island of Oahu, by decade, 1881-1985.

20. Number and percentage of wells, tunnels, and shafts drilled or constructed for ground-water development and still in existence in 1985 , island of Oahu

21. Generalized distribution of wells, tunnels, and shafts drilled or constructed for ground-water development in each ground-water flow system and still in existence in 1985, island of Oahu

22. Ground-water pumpage from the volcanic-rock aquifers of each ground-water flow system, island of Oahu, by decade, $1901-80$

23. Acres planted in sugarcane, island of Oahu, 1930-85

24. Generalized distribution of mean annual ground-water pumpage from each ground-water flow system, island of Oahu, by decade, 1901-80

25. Idealized diagram of a water-development tunnel

26. Idealized diagram of a water-development shaft

27. Graph showing representative ground-water levels for ground-water areas island of Oahu ......

28. Circular diagrams showing components of water budget for each ground-water flow system, island of Oahu

29. Circular diagram showing generalized total water budget, island of Oahu

30-33. Maps showing:

30. Distribution of estimated predevelopment ground-water recharge to and discharge from the noncaprock areas of the northern and southern ground-water flow systems, island of Oahu

31. Distribution of estimated predevelopment ground-water recharge to and discharge from eastern, southeastern, and western ground-water flow systems, island of Oahu .

32. Areas of sugarcane cultivation in southern Oahu, mid-1980's conditions

33. Areas of sugarcane cultivation in southern Oahu, mid-1950's conditions

\section{TABLES}

TABLE 1. Mean, maximum, and minimum annual precipitation for selected stations, island of Oahu ............................................ 8

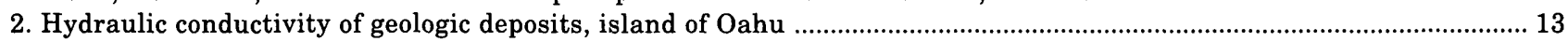

3. Hydraulic properties of dike-free lava flows estimated from aquifer tests, island of Oahu ........................................... 13

4. Estimated annual mean daily spring discharge, Pearl Harbor springs area, island of Oahu, by decade, 1911-80 ......... 27

5. Number of wells, tunnels, and shafts drilled or constructed for ground-water development each decade, 1881-1985, in each ground-water flow system, island of Oahu

6. Number of wells, tunnels, and shafts drilled or constructed for ground-water development each decade that are still in existence in 1985, by use category, island of Oahu

7. Number of wells, tunnels, and shafts drilled or constructed for ground-water development in each ground-water flow system, 1881-1985, by use category, island of Oahu

8. Population of Honolulu and island of Oahu

9. Summary of mean annual ground-water pumpage for each ground-water area, island of Oahu, by decade, $1901-80$

10. Summary of mean annual ground-water pumpage for the ground-water flow systems, island of Oahu, by decade, $1901-80$

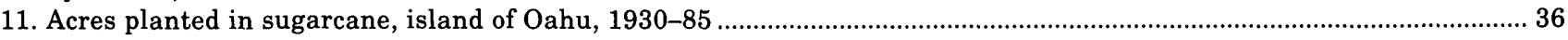

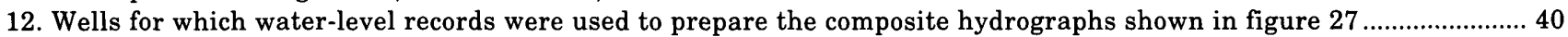




\section{TABLES}

13. Estimated predevelopment water budget for ground-water flow systems, island of Oahu .................................... 42

14. Distribution of estimated predevelopment ground-water recharge in the central ground-water flow system, island of Oahu

15. Estimated water budget for 1980's land use for ground-water flow systems, island of Oahu

16. Estimated ground-water recharge for predevelopment and average 1950's land use used in the numerical analysis of ground-water flow in the southern Oahu ground-water flow system in the noncaprock areas of southern Oahu ... 48

17. Comparison of mean annual ground-water pumpage, island of Oahu 1921-50 and 1951-58

\section{CONVERSION FACTORS}

\begin{tabular}{rll} 
Multiply & By & To obtain \\
\hline cubic foot per day per foot $\left(\mathrm{ft}^{3} / \mathrm{d} / \mathrm{ft}\right)$ & 0.0283 & cubic meter per day \\
foot squared per day $\left(\mathrm{ft}^{2} / \mathrm{d}\right)$ & 0.0929 & square meter per day \\
square mile $\left(\mathrm{mi}^{2}\right)$ & 2.590 & square kilometer \\
inch $(\mathrm{in})$. & 25.40 & millimeter \\
foot $(\mathrm{ft})$ & 0.3048 & meter \\
$\mathrm{mile}(\mathrm{mi})$ & 1.609 & kilometer \\
mile per hour $(\mathrm{mi} / \mathrm{h})$ & 1.609 & kilometer per hour \\
foot per day $(\mathrm{ft} / \mathrm{d})$ & 0.3048 & meter per day \\
foot per mile $(\mathrm{ft} / \mathrm{mi})$ & 0.1894 & meters per kilometer \\
million gallons per day $(\mathrm{Mgal} / \mathrm{d})$ & 0.04381 & cubic meter per second \\
\hline
\end{tabular}

Temperature is given in degrees Celsius $\left({ }^{\circ} \mathrm{C}\right)$, which can be converted to degrees Fahrenheit $\left({ }^{\circ} \mathrm{F}\right)$ by the following equation:

$$
{ }^{\circ} \mathrm{F}=1.8\left({ }^{\circ} \mathrm{C}\right)+32
$$




\title{
REGIONAL AQUIFER-SYSTEM ANALYSIS-OAHU, HAWAII
}

\section{SUMMARY OF THE OAHU, HAWAII, REGIONAL AQUIFER-SYSTEM ANALYSIS}

\author{
By William D. Nichols, Patricia J. Shade, and Charles D. Hunt, JR.
}

\begin{abstract}
Oahu, the third largest of the Hawaiian islands, is formed by the eroded remnants of two elongated shield volcanoes with broad, low profiles. Weathering and erosion have modified the original domed surfaces of the volcanoes, leaving a landscape of deep valleys and steep interfluvial ridges in the interior highlands. The Koolau Range in eastern Oahu and the Waianae Range in western Oahu are the eroded remnants of the Koolau and Waianae Volcanoes.

The origin, mode of emplacement, texture, and composition of the rocks of Oahu affect their ability to store and transmit water. The volcanic rocks are divided into four groups: (1) lava flows, (2) dikes, (3) pyroclastic deposits, and (4) saprolite and weathered basalt. Stratified sequences of thin-bedded lava flows form the most productive aquifers in Hawaii. Dikes are near-vertical sheets of massive intrusive rock that typically contain only fracture permeability. Pyroclastic deposits include ash, cinder, and spatter; they are essentially granular, with porosity and permeability similar to those of granular sediments. Weathering of basaltic rocks in the humid, subtropical climate of Oahu alters igneous minerals to clays and oxides, reducing the permeability of the parent rock. Saprolite is weathered material that has retained textural features of the parent rock.

Estimates of hydraulic conductivity along the plane of dikefree lava flows tend to fall within about one order of magnitude, from about 500 to about 5,000 feet per day. Estimates of specific yield range from about 1 to 20 percent; most of the values lie within a narrow range of about 5 to 10 percent.

The occurrence of ground water on Oahu is determined by the type and character of the rocks and by the presence of geohydrologic barriers. The primary modes of freshwater occurrence on Oahu are as a basal lens of fresh ground water floating on saltwater, as dike-impounded ground water, and as perched ground water. Saltwater occurs at depth throughout much of the island.

A regional aquifer system composed of the Waianae aquifer in the Waianae Volcanics and the Koolau aquifer in the Koolau Basalt is subdivided into well-defined areas by geohydrologic
\end{abstract}

barriers. The aquifers are separated by the Waianae confining unit formed by weathering along the Waianae-Koolau unconformity. In some coastal areas, a caprock of sedimentary deposits overlies and confines the aquifers.

The island of Oahu has been divided into seven major ground-water areas delineated by deep-seated structural geohydrologic barriers; these areas are further subdivided by shallower internal barriers to ground-water flow. The Koolau rift zone along the eastern (windward) side of the island and the Waianae rift zone to the west (Waianae area) constitute two of the major ground-water areas. North-central Oahu is divided into three smaller ground-water areas, Mokuleia, Waialua, and Kawailoa. The Schofield ground-water area encompasses much of the Schofield Plateau of central Oahu. Southern Oahu is divided into six areas, Ewa, Pearl Harbor, Moanalua, Kalihi, Beretania, and Kaimuki. Southeastern Oahu is divided into the Waialae and Wailupe-Hawaii Kai areas. Along the northeast coast of windward Oahu is the Kahuku ground-water area.

The aquifers of Oahu contain shallow freshwater and deeper saltwater flow systems. There are five fresh ground-water flow systems: meteoric freshwater flow diverges from ground-water divides that lie somewhere within the Waianae and Koolau rift zones, forming an interior flow system in central Oahu (which is divided into the northern and southern Oahu flow systems) and exterior flow systems in western (Waianae area) Oahu, eastern (windward) Oahu, and southeastern Oahu.

Development of the ground-water resources on Oahu began when the first well was drilled near Honouliuli in the summer of 1879 . By 1890,86 wells had been drilled on the island. From about 1891 to about 1910, development increased rapidly with the drilling of a large number of wells for irrigation of sugarcane in southern and northern Oahu and in the Kahuku area of windward Oahu. By 1985, at least 1,635 wells, shafts, and tunnels had been drilled on Oahu for the development of ground-water resources.

Before 1900, few records of ground-water pumpage were kept, and from 1901 to 1910, the available records are incomplete. Ground-water pumpage from the volcanic-rock aquifers from 1901 to 1910 averaged at least 90 million gallons per day. Pumpage increased to about 160 million gallons per day dur- 
ing the following decade and by the decade ending in 1930 averaged about 217 million gallons per day Ground-water pumpage from the volcanic-rock aquifers for all uses increased from an average of about 320 million gallons per day in 1941 to 413 million gallons per day in 1970. Ground-water pumpage from all sources averaged about 394 million gallons per day in 1980 . Of this, about 81 percent, or 318 million gallons per day, was pumped from the volcanic-rock aquifers of the island, with 238 million gallons per day being pumped from the southern Oahu area alone. About 19 percent, or 76 million gallons per day, of the total from all sources was derived from water-development tunnels, flowing wells, and pumpage from aquifers in the caprock.

A predevelopment water budget was estimated for each of the ground-water flow systems of Oahu and for the island of Oahu. Mean annual ground-water recharge to the combined caprock and noncaprock areas was estimated to be about 792 million gallons per day, representing about 40 percent of mean annual precipitation. About 16 percent of mean annual precipitation becomes runoff and 44 percent is lost to evapotranspiration. Of the 521 million gallons per day of ground-water recharge to the noncaprock areas of southern and northern Oahu, about 199 million gallons per day derives from the Schofield ground-water area and those parts of the Koolau and Waianae rift zone adjacent to the Schofield area. About 103 million gallons per day is estimated to move as underflow from the southern Schofield area into the Pearl Harbor and Ewa ground-water areas in southern $\mathrm{Oahu}$; about 96 million gallons per day moves as underflow from the northern Schofield area into the Waialua ground-water area in northern Oahu.

A conceptual model of the southern Oahu ground-water flow system was not altered significantly by the results of steadystate simulation. Three modifications were made to the configuration of the initial steady-state model during model calibration: (1) hydraulic conductivity in the basalt aquifers was determined to be areally anisotropic; (2) the hydraulic conductivity of the caprock confining layer was not uniform and varied from one subarea to another; and (3) the original estimate of irrigation return flow was too large.

\section{INTRODUCTION}

The island of Oahu is the third largest of the eight major islands of the Hawaiian islands. It supported a population of nearly 850,000 people in 1990 . Sixty-eight percent of all water, including seawater, used for municipal, industrial, commercial, and agricultural purposes on Oahu is obtained from ground water. By 1980 nearly $400 \mathrm{Mgal} / \mathrm{d}$ of ground water were pumped from all the aquifers of Oahu for all uses, representing 90 percent of the freshwater used on the island (Nakahara, 1984). Estimates of the long-term potential yield of the ground-water system of Oahu range from 480 to $635 \mathrm{Mgal} / \mathrm{d}$ (Ewart, 1986). The main source of recharge to the ground-water reservoir is precipitation, which may be augmented by irrigation-return flow in some areas.
The economy of Oahu, and indeed of most of the State of Hawaii, is dependent on ground water for continued growth and prosperity. However, declining ground-water levels and potential contamination of the island's fresh ground water by saltwater intrusion and by organic compounds are cause for concern regarding the future use of this resource.

Prompted by the drought of 1977, the United States Congress appropriated funds in 1978 for the U.S. Geological Survey to begin the Regional Aquifer-System Analysis (RASA) program. The purpose of this program is to define the regional hydrology and geology and to establish a framework of background information of geology, hydrology, and geochemistry of the Nation's important aquifer systems (Sun, 1986). This information is needed to develop a better understanding of these systems and to support better ground-water resources management (Sun, 1986). The Oahu RASA study began in 1982 as one of 25 regional-aquifer systems studied under the RASA program.

\section{PURPOSE AND SCOPE}

The purpose of Professional Paper 1412 is to describe major aspects of the hydrology and geology of the regional aquifer system underlying the island of Oahu. These descriptions are derived from study results and preliminary reports of the Oahu RASA and also from the hydrologic literature of Oahu. Professional Paper 1412 consists of three chapters as follows:

Chapter A (this report) summarizes the geohydrology of Oahu with emphasis on the occurrence of ground water, rates of recharge and discharge, the history of ground-water development, and an analysis of groundwater flow in the hydrologically important southern Oahu area.

Chapter B (Hunt, in press) describes the geohydrologic framework of Oahu, specifically the modes of occurrence of ground water, subdivision of the island into ground-water areas and flow systems, and hydraulic properties of the basalt aquifers and associated rocks.

Chapter C (Shade and Nichols, 1996) presents water budgets for Oahu for predevelopment and mid-1980's conditions.

\section{STUDY AREA}

The study area encompasses the entire island of Oahu (fig. 1) covering $604 \mathrm{mi}^{2}$, of which $593 \mathrm{mi}^{2}$ are land area (University of Hawaii Department of Geography, 1983). It is the most heavily populated of the islands; in 1980, the population was 765,565 (Hawaii Department of Planning and Economic Development, 1983) and, by 1990 , the population had risen to 836,231 (U.S. Depart- 


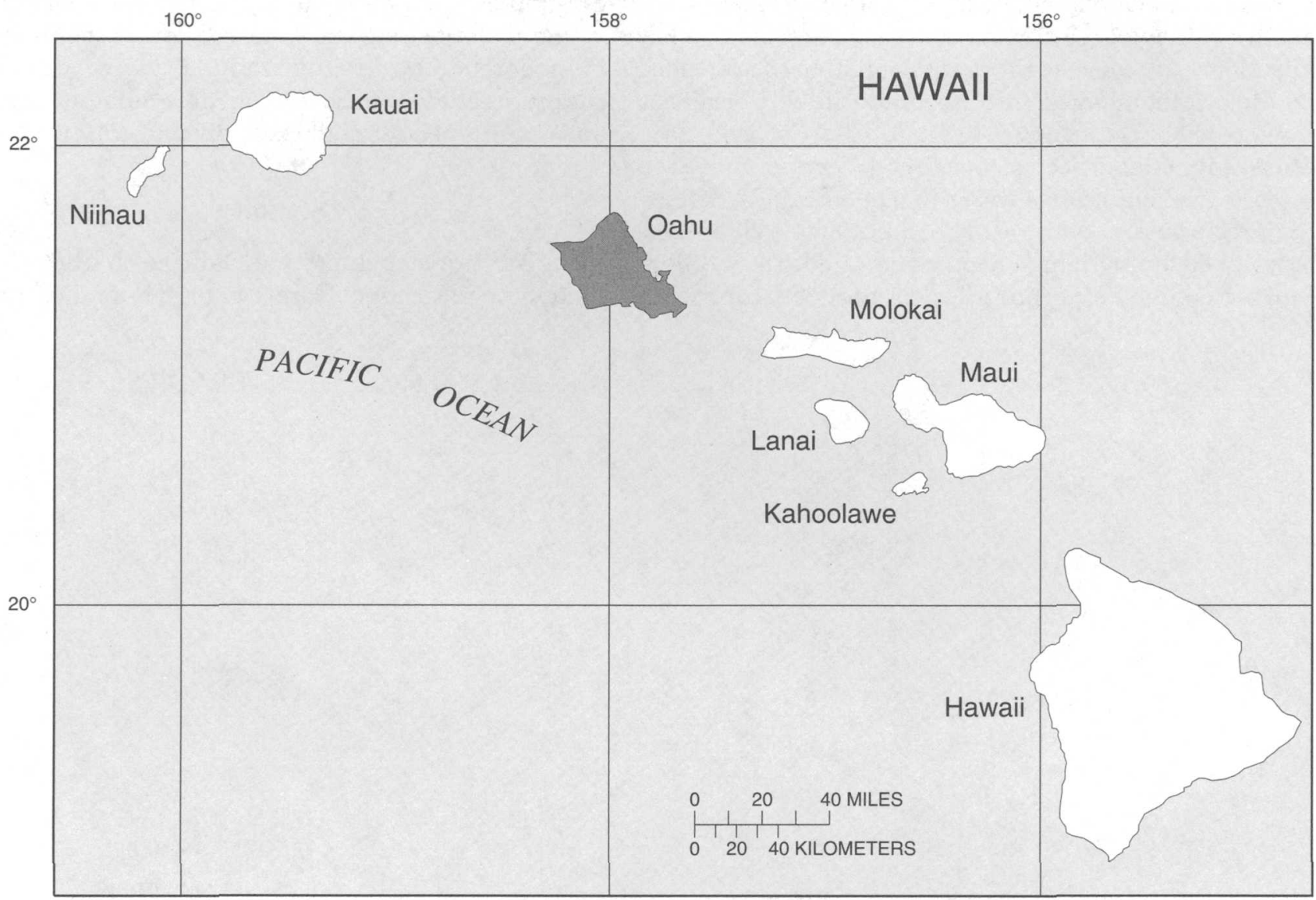

Figure 1.-Location of Oahu in the Hawaiian Islands.

ment of Commerce, 1992). Oahu is the center of commerce, industry, and government in Hawaii and is the site of the State capital, Honolulu (fig. 2). Principal elements of the economy are tourism, agriculture, and government expenditures.

Although Oahu is the most populous of the Hawaiian islands, much of its land area is forested or cultivated (fig. 3). Most of the population is concentrated in urban centers near the coast. Gently sloping upland areas are planted in sugarcane and pineapple, but urban development has expanded progressively on these areas in recent decades. The rugged, mountainous terrain of Oahu is mostly forested conservation land, typically designated as watershed preserves. Intensive urban and agricultural development on Oahu creates high demand for water. Most of this demand is supplied by ground water.

\section{PHYSICAL SETTING}

The Hawaiian islands stretch for 1,600 mi from southeast to northwest along the Hawaiian Ridge between longitude $155^{\circ}$ to $179^{\circ} \mathrm{W}$. and latitude $19^{\circ}$ to $28^{\circ} \mathrm{N}$. It includes 132 islands, reefs, and shoals. Oahu (fig. 1), the third largest of the Hawaiian islands, is formed by the eroded remnants of two elongated shield volcanoes with broad, low profiles. Weathering and erosion have modified the original domed surfaces of the volcanoes, leaving a landscape of deep valleys and steep inter-fluvial ridges in the interior highlands. The Koolau Range in eastern Oahu and the Waianae Range in western Oahu are the eroded remnants of the Koolau and Waianae Volcanoes (fig. 2). In central Oahu, which forms the saddle between the Waianae and Koolau Ranges, erosion has been less severe and has modified the original volcanic domes only slightly.

A flat coastal plain composed of sedimentary deposits, referred to as caprock, surrounds much of Oahu (fig.4). The caprock varies in width from a narrow marine terrace to a broad plain several miles wide. Where it is extensive, such as in southern Oahu, its surface is composed mainly of emerged Pleistocene reefs and associated sediments. 
Streams on Oahu are short, with steep gradients and small drainage areas. Main courses of streams generally follow the consequent drainage pattern established on the original domed surfaces of the shield volcanoes. Lower-order tributaries branch off from the main courses in a dendritic pattern. Steep terrain and steep stream gradients cause water to run off rapidly following precipitation. As a result, streamflow is characteristically flashy, with high flood peaks and little baseflow. Few streams are perennial over their entire reach.
Streamflow is perennial at high altitudes where precipitation is persistent and near sea level where streams intercept shallow ground water. These conditions virtually preclude surface-water development on Oahu and lead to heavy reliance on ground water.

\section{CLIMATE}

The subtropical climate of Oahu is characterized by mild temperatures, moderate to high humidity that var-

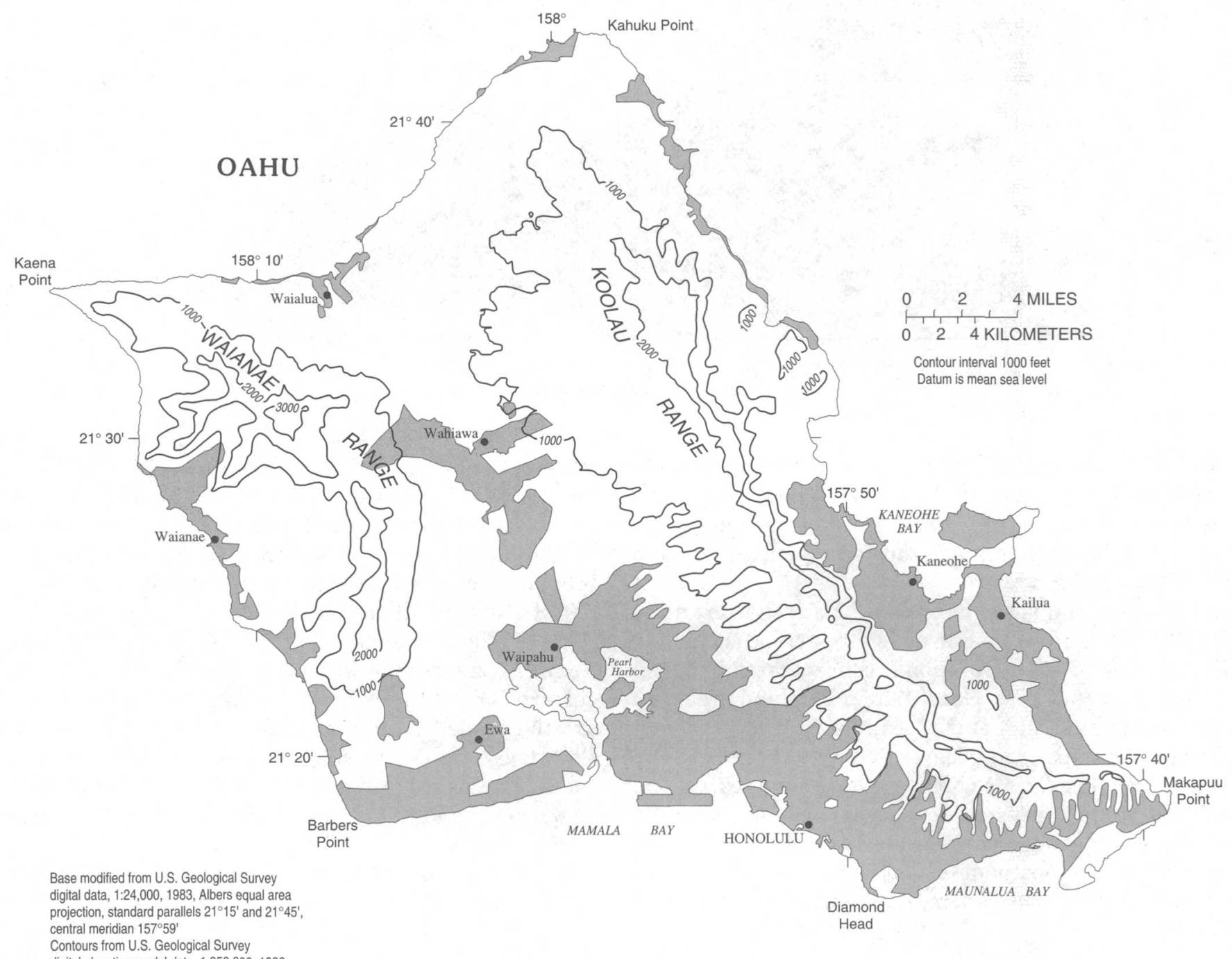

Contours from U.S. Geological Survey

digital elevation model data, 1:250,000, 1986

EXPLANATION

URBAN AREA

FigurE 2.-Topography and geographic features, island of Oahu. 
ies diurnally from about 60 to 90 percent at most locations, prevailing northeasterly tradewinds that average about $9 \mathrm{mi} / \mathrm{h}$ in January and about $13 \mathrm{mi} / \mathrm{h}$ in June, and extreme variation in precipitation over short distances. Climate varies spatially with altitude and in relation to prevailing and local winds. Mean annual temperature is about $76{ }^{\circ} \mathrm{F}$ in lowland Honolulu, decreasing to less than $70{ }^{\circ} \mathrm{F}$ in the mountainous uplands (Blumenstock and Price, 1967).
A pronounced orographic pattern of cloud cover and precipitation is established as moist oceanic air is forced up and over the mountainous terrain of Oahu by persistent tradewinds. Mean annual precipitation (fig. 5) has a steep orographic gradient and varies widely, ranging from less than 40 to about $60 \mathrm{in} / \mathrm{yr}$ on the northern and windward (northeastern) coast, to about $275 \mathrm{in} / \mathrm{yr}$ near the crest of the Koolau Range, to less than 25 $\mathrm{in} / \mathrm{yr}$ over the leeward (southwestern) lowlands. The

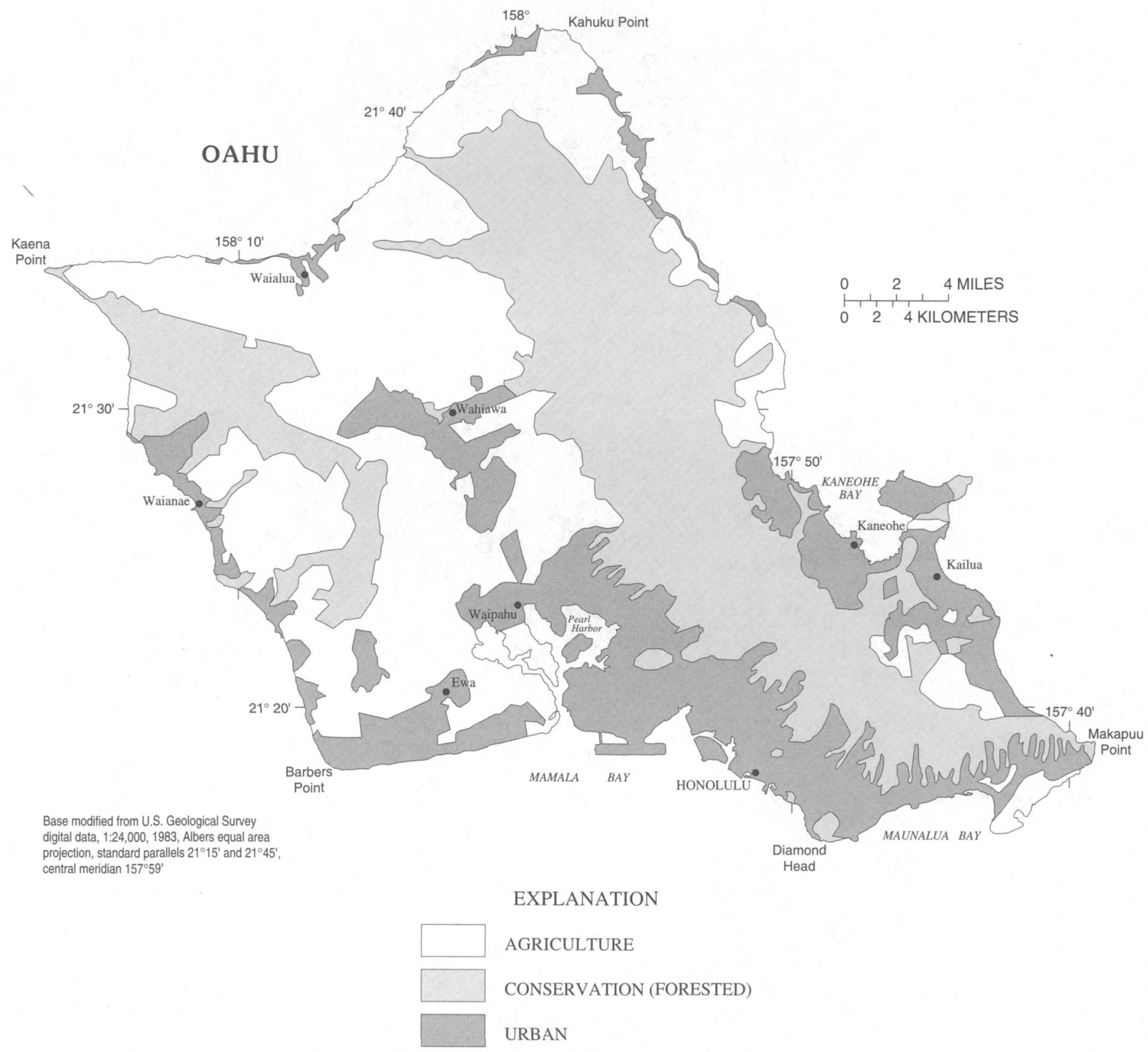

Figure 3.-Land use, island of Oahu (modified from State of Hawaii Department of Agriculture, 1980). 


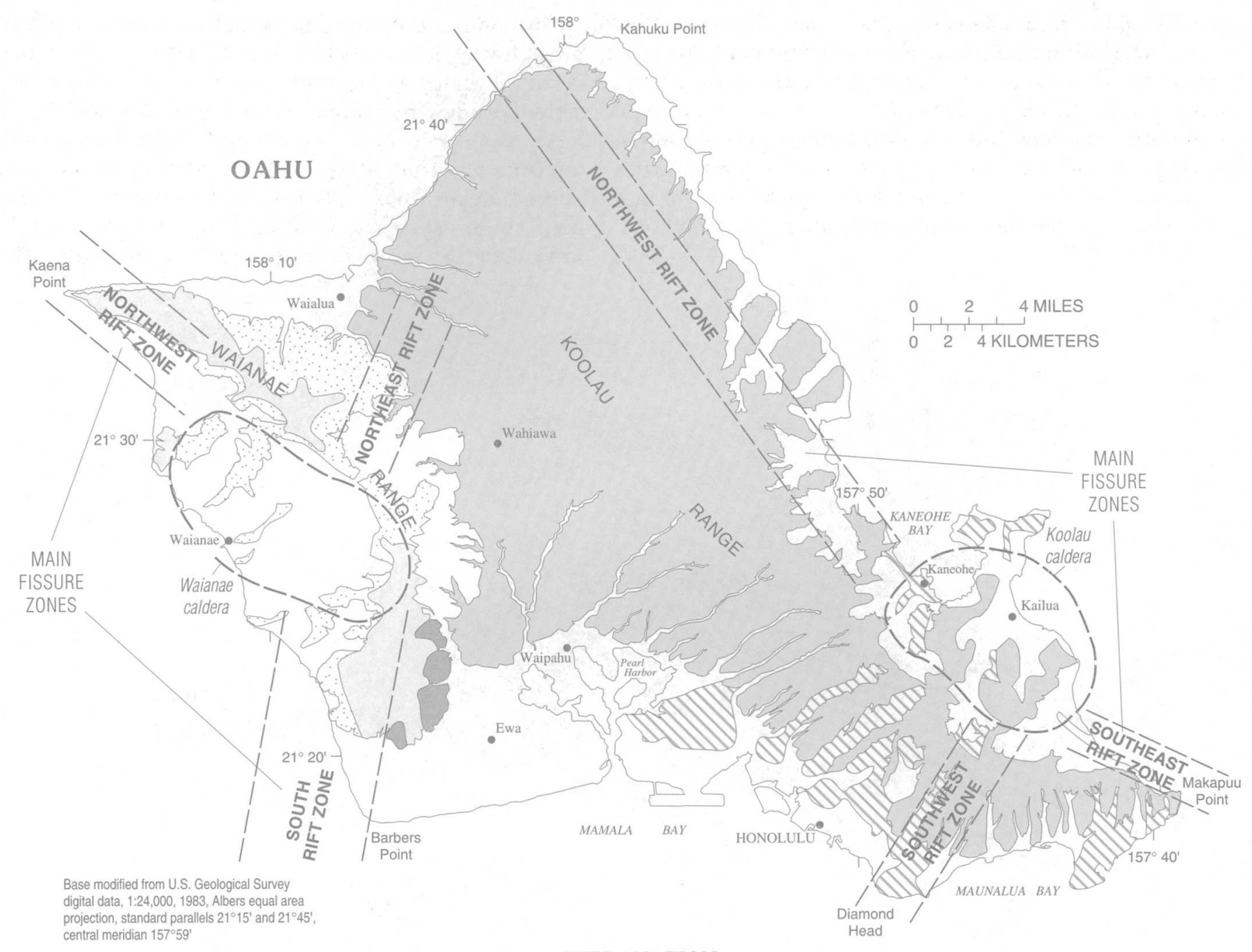

EXPLANATION

$\square$ SEDIMENTARY DEPOSITS (CAPROCK) (HOLOCENE AND PLEISTOCENE)

WAIANAE VOLCANO

KOLEKOLE VOLCANICS (PLEISTOCENE)

WAIANAE VOLCANICS (PLIOCENE)

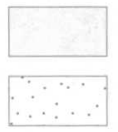

Palehua Member

Kamaileunu and Lualualei Members, undivided (Kamaileunu Member includes Mauna Kuwale Rhyodacite Flow)

KOOLAU VOLCANO

AIIIV HONOLULU VOLCANICS (HOLOCENE (?) AND PLEISTOCENE)

$\square$ KOOLAU BASALT (PLEISTOCENE (?), AND PLIOCENE, INCLUDES KAILUA MEMBER)

二二二 GENERALIZED RIFT ZONE

- - C CALDERA RING FAULT - Approximately located

Figure 4.-Generalized geology, island of Oahu (modified from Stearns and Macdonald, 1940; Stearns, 1946; Sinton, 1986;

Langenheim and Clague, 1987) showing calderas of the Waianae and Koolau Volcanoes (modified from Macdonald, 1972). 
Waianae Range lies in the tradewind rainshadow of the Koolau Range and receives much less precipitation, with a maximum of about $80 \mathrm{in} / \mathrm{yr}$ falling on the Waianae summit. Annual precipitation for selected stations is shown in figure 6. Statistics for these stations are given in table 1 . Mean annual precipitation over the open ocean near Oahu is about 25 in. (Blumenstock and Price, 1967).

Precipitation over much of Oahu is markedly seasonal (fig. 7). In lowland and coastal areas, the wetter winter months, October through April, receive about 70 percent of the total annual precipitation. Mountainous areas, particularly the Koolau Range, receive a fairly steady contribution of tradewind precipitation that is supplemented by intense, episodic rains from hurricanes, winter cold fronts, and convective disturbances associated with low pressure in the upper atmosphere.

\section{PREVIOUS STUDIES}

The geology and ground-water hydrology of Oahu have been studied in great detail and are the subject of

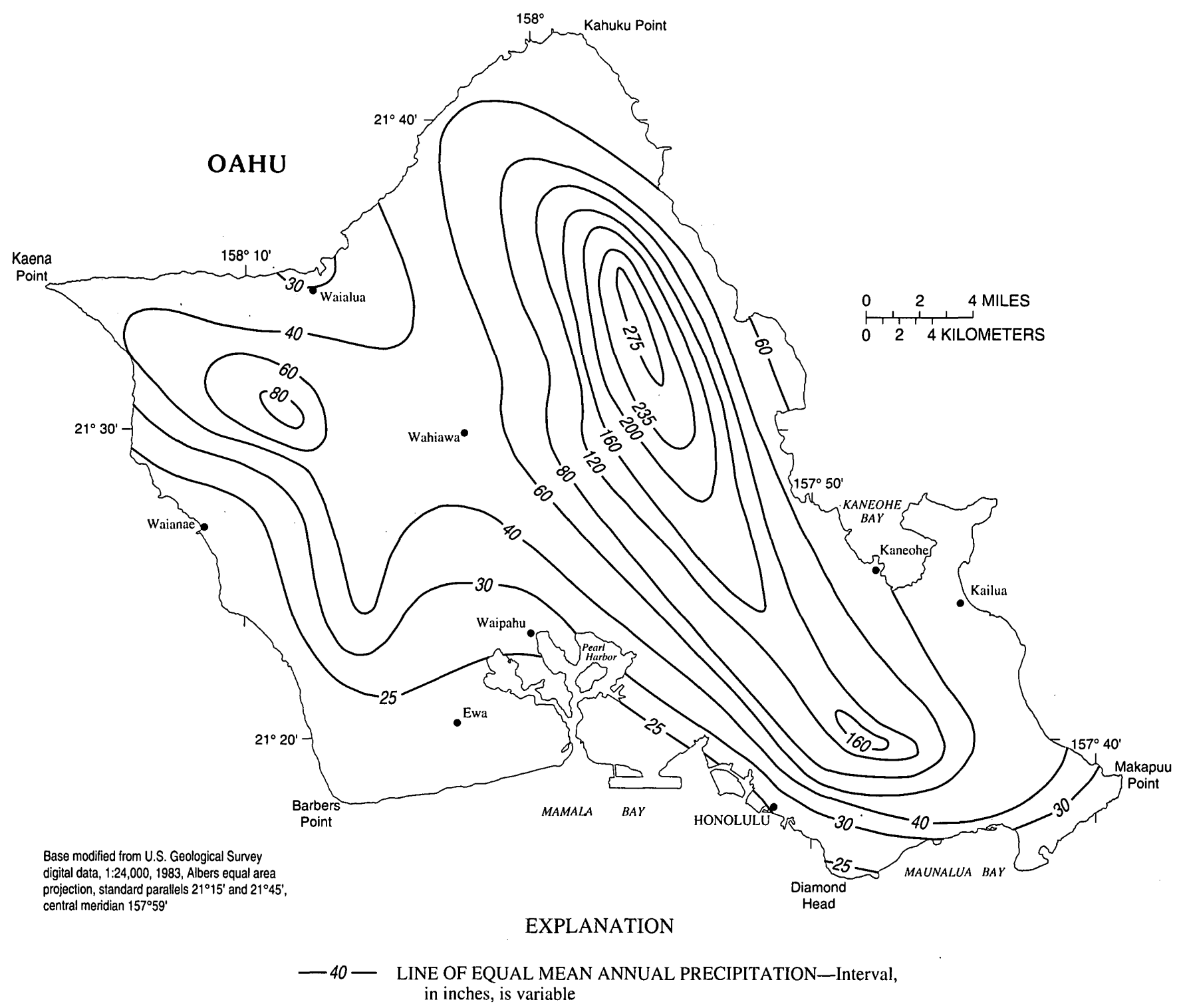

FigURE 5.-Mean annual precipitation, 1916-83, island of Oahu (after Giambelluca and others, 1986). 
TABLE 1.-Mean, maximum, and minimum annual precipitation for selected stations, island of Oahu [Location of station shown in figure 6; all values in inches per year]

\begin{tabular}{lccccc}
\hline Station name & Mean & Maximum & Minimum & Standard deviation & Period of record \\
\hline Waimea 3 & 48.55 & 77.26 & 20.51 & 11.61 & $1917-82$ \\
Waiawa & 147.66 & 311.23 & 91.55 & 36.79 & $1917-83$ \\
Nuuanu Reservoir 4 & 128.50 & 211.45 & 66.86 & 32.66 & $1905-83$ \\
Makapuu Point & 24.24 & 59.46 & 2.43 & 14.25 & $1907-73$ \\
Honolulu & 25.41 & 45.51 & 10.3 & 9.27 & $1905-85$ \\
Waipahu & 25.30 & 49.44 & 7.13 & 10.35 & $1897-85$ \\
Waianae Mauka & 68.34 & 117.27 & 39.14 & 15.64 & $1905-73$ \\
Helemano 7 & 40.17 & 125.54 & 15.66 & 16.72 & $1931-83$ \\
\hline
\end{tabular}
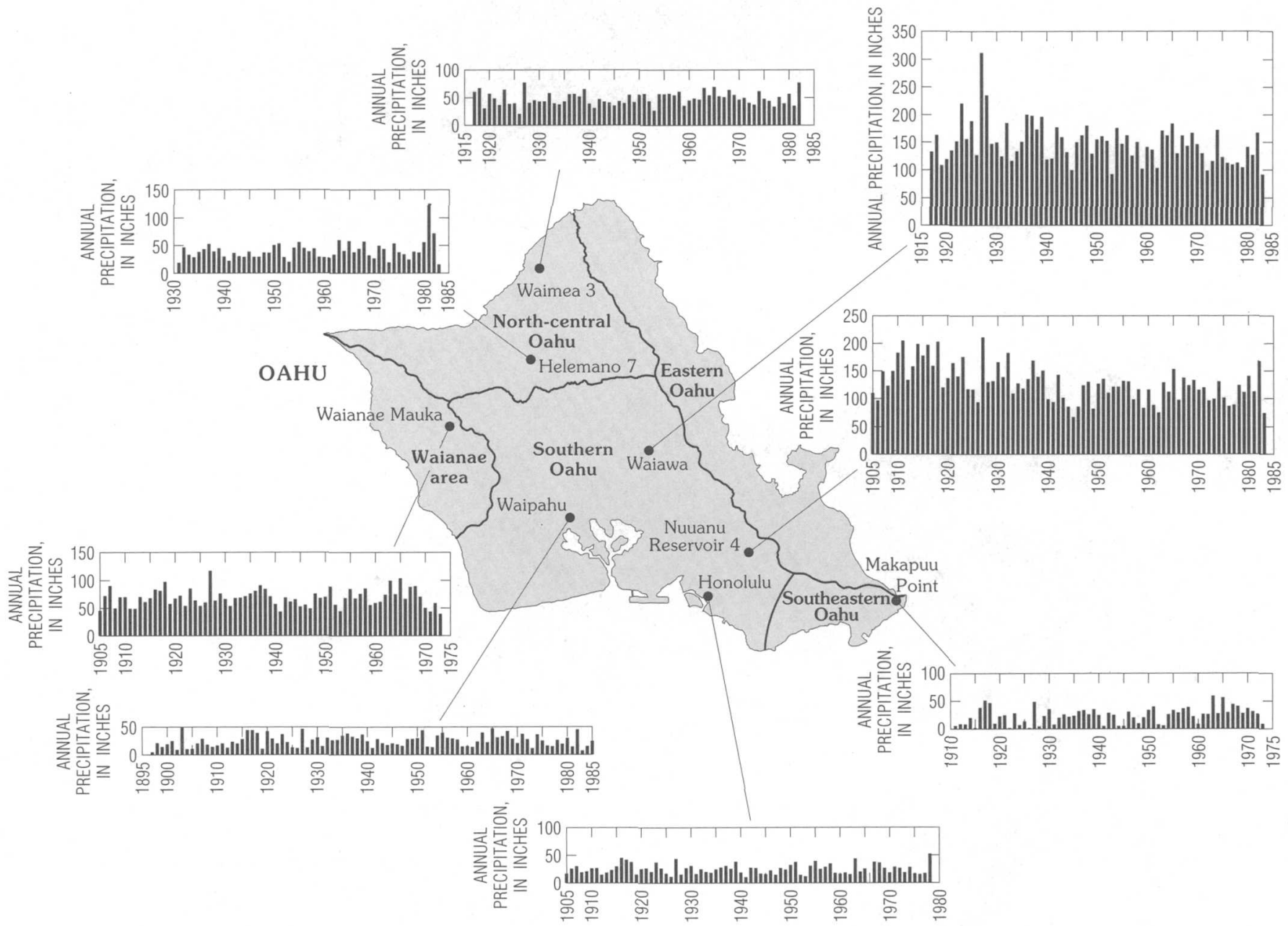

FiguRE 6.-Annual precipitation at selected stations, island of Oahu. 
numerous reports. Descriptions of ground-water occurrence and geologic formations are presented in reports by Stearns and Vaksvik (1935, 1938), Stearns and Macdonald (1940), and Wentworth (1942, 1945, 1951). Stearns (1939) presented a detailed geologic map of Oahu. Other important studies of the geology of Oahu include those of Hitchcock (1900), Wentworth (1926, 1951), Palmer (1927, 1946), Stearns (1940, 1946, 1985), Wentworth and Winchell (1947), Winchell (1947), and Macdonald and others (1983). Sinton (1986) presented a revised geologic map and stratigraphic nomenclature for the Waianae Volcano, and the stratigraphic nomenclature for all of Oahu was reviewed and updated by Langenheim and Clague (1987). Walker $(1986,1987)$ presented detailed descriptions of the dike complex of the Koolau Volcano.
The hydrology of Oahu is described in various reports by the U.S. Geological Survey; the Honolulu Board of Water Supply; the State of Hawaii, Department of Land and Natural Resources; the University of Hawaii, Water Resource Research Center; and in various doctoral dissertations and masters theses. Early works of particular importance include those of Wentworth (1926, 1951), Palmer (1927, 1946), Stearns and Vaksvik (1935), and Stearns (1940). Visher and Mink (1964) discussed the ground-water resources of southern Oahu, which includes the Pearl Harbor area. Takasaki and others (1969) described the water resources and the development of dike-impounded ground water of windward Oahu. Takasaki and Valenciano (1969) discussed the geohydrology and water resources of the Kahuku area. Rosenau and others (1971) described the water re-

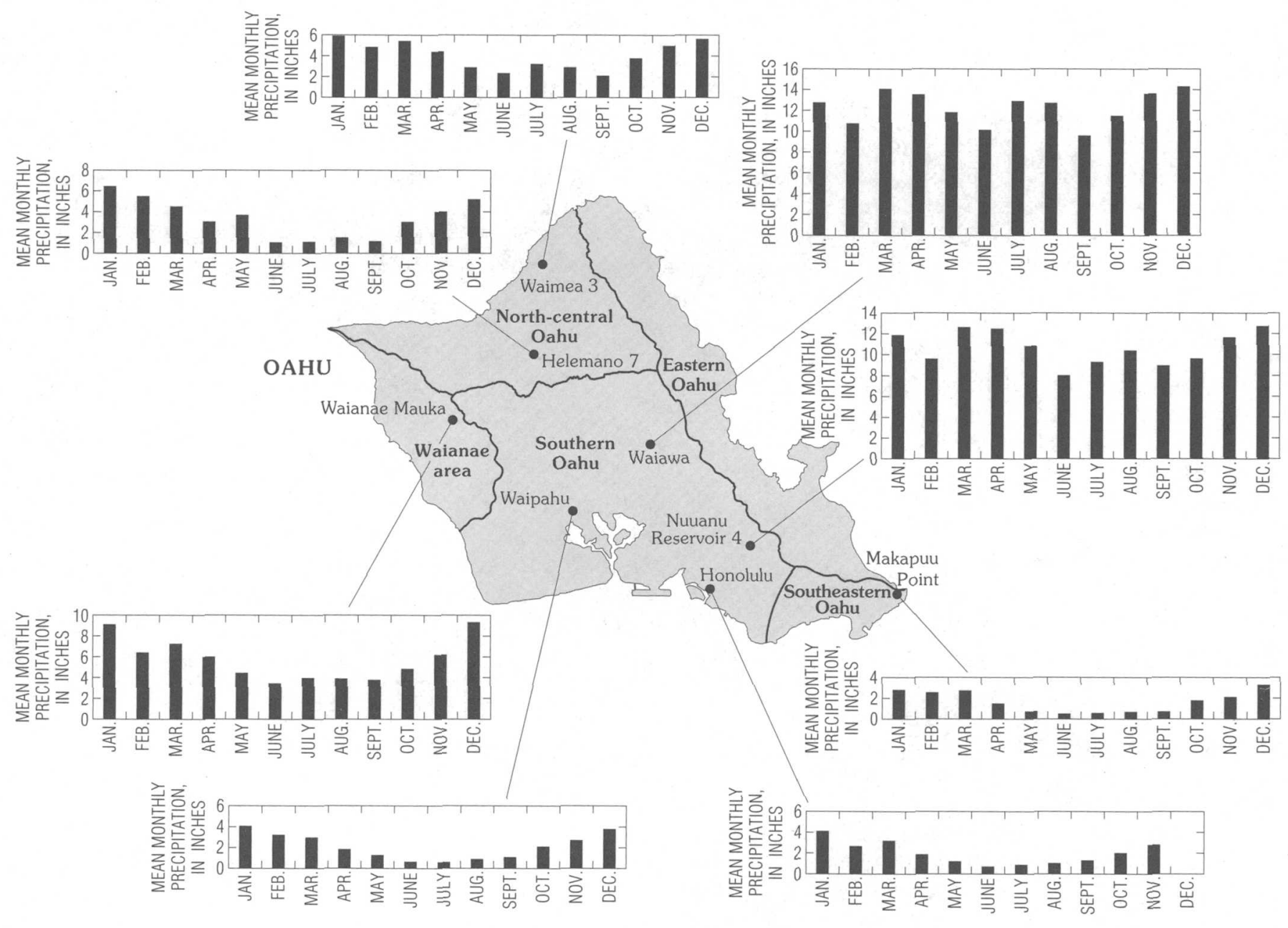

FIGURE 7.-Mean monthly precipitation at selected stations, island of Oahu. 
sources of northern Oahu and estimated ground-water recharge to the area. Dale (1978) analyzed the Waialua area in more detail. Ground water in the Waianae area was described by Takasaki (1971). The effects of increased pumping from the Schofield area were evaluated by Dale and Takasaki (1976). Finally, the water resources of southeastern Oahu were described by Takasaki and Mink (1982). Dike-impounded ground water and the effects of tunnels used to develop this ground-water source in windward Oahu have been described and discussed by Hirashima (1971) and Takasaki and Mink (1985). Compilation and analysis of a large collection of pumping-test data are presented in Soroos (1973) and Williams and Soroos (1973). Historic trends in pumpage, spring flow, water levels, and chloride concentration throughout the Pearl Harbor area are presented by Soroos and Ewart (1979). Water levels and water-quality data at observation wells have been published regularly since 1920 by the Honolulu Board of Water Supply and the U.S. Geological Survey. Giambelluca $(1983,1986)$ estimated ground-water recharge to the Ewa and Pearl Harbor areas for the period 1946-75 using a rigorous numerical approach. Before the studies of Giambelluca, estimates of groundwater recharge had been obtained from water balances that used values of average annual precipitation, runoff, and evapotranspiration averaged over large areas. In contrast, Giambelluca (1983) estimated average monthly recharge over small areas, defined by land use, for each month from 1946 through 1975 using observed monthly precipitation and estimated monthly runoff and evaporation data distributed throughout the study area.

The first areal simulation models of ground-water flow in the southern Oahu area were produced by P.R. Eyre (U.S. Geological Survey, written commun., 1980) and Liu and others $(1981,1983)$ using a version of the U.S. Geological Survey finite-difference numerical model by Trescott and others (1976). The computer code was modified by Eyre to simulate ground-water flow in a freshwater lens floating on seawater. The models reproduced general features of the water-level distribution; however, there were significant differences between simulated and observed water levels indicating that important geohydrologic features had not been properly represented in the models. Using a one-dimensional, lumped-parameter, analytical model of flow in a freshwater lens, Mink (1980) reproduced historical water levels at specific wells and predicted future changes based on projected pumpage and recharge rates. Souza and Voss (1987) have investigated ground-water flow in the Pearl Harbor area. Their study analyzed the flow system in cross section using a variable-density flow and solute-transport simulation model.

\section{GEOLOGIC SETTING}

Oahu and the other Hawaiian islands are the exposed peaks of large volcanic mountain ranges, most of which lie beneath the sea, that comprise the Hawaiian Ridge. The Hawaiian Ridge is thought to have formed by the relative drift of the Pacific lithospheric plate over a convective plume, or hotspot, in the mantle (Wilson, 1963). Continued volcanism at the hotspot and the northwestward relative motion of the Pacific plate produced an apparent southeasterly succession of mountain building, with progressively younger islands to the southeast, and with present volcanic activity occurring at the extreme southeast end of the island chain on the island of $\mathrm{Ha}$ waii. The submarine parts of the Hawaiian Ridge rise about $15,000 \mathrm{ft}$ above the adjacent sea floor before protruding above sea level. The highest point on Oahu is 4,020 ft above sea level in the Waianae Range.

The island of Oahu is formed by the remnants of two coalesced shield volcanoes, the Koolau Volcano to the east and the Waianae Volcano to the west (fig. 4). A shield volcano is formed by eruptions of very fluid lava originating on the ocean floor that builds a dome-shaped structure resembling a shield. Submarine volcanic deposits include pillow lavas, hyaloclastite, and flow-foot breccia. Vitric ash deposits are formed when eruptions occur in shallow water. Eventually, the lavas build to sea level and above, and shield-building continues with quiescent subaerial eruptions of fluid lava. Building of the Waianae and Koolau Volcanoes occurred during the Pliocene and Pleistocene epochs.

The Waianae Volcano is older than the Koolau, in accordance with the southeasterly volcanic succession ascribed to the mechanism of plate motion over a hotspot in the mantle. However, both volcanoes likely erupted concurrently during at least part of their active lifespans, especially in light of their large submarine masses. Shield-building lavas from the two volcanoes may interfinger at depth, although this has not been observed in surface outcrops or in boreholes. At the relatively shallow depths of such observations, lavas from the Koolau Volcano unconformably overlie lavas from the Waianae Volcano, with soil and saprolite having developed on the older Waianae surface and with weathered alluvium separating the two formations in some places (Stearns and Vaksvik, 1935).

The shield-building lavas erupted mainly from prominent rift zones of the Waianae and Koolau Volcanoes (fig. 4). These elongate zones form the topographic crests of the volcanoes and their submarine extensions. Within each rift zone, a dike complex and a marginal dike zone have been delineated (Stearns and Vaksvik, 1935; Takasaki and Mink, 1985). Dikes are most heavily concentrated in the dike complexes where they commonly 
number several hundred per mile and constitute 10 percent or more of the total rock. In the marginal dike zones, dikes commonly number less than 100 per mile and account for less than 5 percent of the total rock (Wentworth, 1951; Takasaki and Mink, 1985). Most of the dikes dip steeply and are arranged in a subparallel pattern roughly aligned to the general trends of the rift zones. Away from the rift zones, on the flanks of the volcanoes, dikes are sparse or absent.

Near the end of the growth of the shields, the summits of the volcanoes collapsed and formed calderas (however, recent theory indicates that caldera collapse occurs at various times in the growth cycle of shield volcanoes). Finally, a late stage of post-caldera rejuvenated volcanism occurred during middle and late Pleistocene time. These eruptions involved more viscous lavas and were more violent than the shield-building eruptions. Cinder cones and steep-sided volcanic deposits formed during this stage in contrast to the gentle slopes of the underlying shield volcanoes.

The shield-building rocks of the Waianae and Koolau Volcanoes are known respectively as the Waianae Volcanics and the Koolau Basalt (Swanson and others, 1981; Langenheim and Clague, 1987). The Waianae Volcanics are lithologically diverse and encompass both shield and postshield stages of activity (Langenheim and Clague, 1987). Waianae Volcanics are mainly lavas and feeder dikes of tholeiitic and alkalic basalt with lesser amounts of talus breccia, explosion breccia, cinder, and spatter. Thin soils and ash beds are intercalated with the lavas. Lava flows of the Waianae Volcanics constitute the principal water-bearing rocks of western Oahu. Radiometric dating of basalt samples from subaerial sites yield ages of 2.5 to $3.9 \mathrm{Ma}$ (million years) for Waianae Volcanics (Clague and Dalrymple, 1987; Langenheim and Clague, 1987).

The Koolau Basalt is wholly of basaltic composition and consists of tholeiitic basalt lavas and feeder dikes with lesser amounts of talus breccia, explosion breccia, cinder, and spatter. Thin soils and ash beds are intercalated with the lavas, although more sparingly than in the Waianae Volcanics. Lava flows of Koolau Basalt constitute the principal water-bearing rocks of central and eastern Oahu. Radiometric dates of samples from subaerial exposures range from 1.8 to $2.6 \mathrm{Ma}$ (Clague and Dalrymple, 1987; Langenheim and Clague, 1987).

The shield volcanoes of Oahu have undergone substantial modification by secondary geologic processes. Gravitational loading of the lithospheric plate by the massive shields caused downwarping of the plate and subsidence of the volcanoes. Slope instability has led to large-scale slumping and landslides. Chemical weath- ering of easily decomposed basaltic rocks produced erodible soil and thick zones of clay-rich saprolite. Streams dissected the shields, eroding material and redepositing it in valleys or transporting it to the coastal estuaries and the sea.

Subsidence was contemporaneous with shield development and continued long after eruptions ceased. Moore and Campbell (1987), in a study of tilted, deeply submerged reefs in the Hawaiian islands, concluded that subsidence ended about $0.5 \mathrm{Ma}$ after the end of shield-building volcanism. Moore (1987) provides a comprehensive summary of this evidence for the Hawaiian islands, together with new evidence and analysis, and concluded that most of the volcanoes have subsided 6,500 to $13,000 \mathrm{ft}$. Lavas that originally were erupted subaerially and have textural characteristics of subaerial lavas have since been carried to great depths by this subsidence.

Fluvial erosion has cut stream valleys several thousand feet deep in both the Waianae and Koolau shields. Much of the western part of the Waianae shield and much of the eastern side of the Koolau shield have been removed leaving remnants of the shields as the Waianae and Koolau Ranges. Sedimentary deposition proceeded concurrently with subsidence and continued after submergence. Shelves built by coral reefs and sediment were submerged and are now found at various depths around Oahu. Valleys that had been cut very early in the erosional period were filled by marine, estuarine, and fluvial sediments as island subsidence raised the base level of streams and drowned their lower reaches.

After the long period of subsidence and erosion, eruptive activity resumed at scattered vents at the southern ends of the Koolau and Waianae Ranges. Rocks of the Waianae rejuvenated stage are called the Kolekole Volcanics (Sinton, 1986) and those of the Koolau rejuvenated stage are called the Honolulu Volcanics (Langenheim and Clague, 1987). Kolekole Volcanics are small in areal extent, comprising about six cinder cones and associated lava flows and ash, mostly at the southern end of the Waianae Range (Sinton, 1986). Radiometric ages are not available for these deposits. Honolulu Volcanics are limited in areal extent, occurring only near the southeastern end of the Koolau Range. The rocks are strongly alkalic and range in composition from alkalic basalt, basanite, and nephelite to melilitite (Clague and Dalrymple, 1987, p. 51). A large proportion of the rocks are pyroclastic products such as ash, cinder, spatter, and tuff. Eruptions inland from the coast left deposits of black ash and cinder and produced lavas that flowed down valleys and spread out over the coastal plain. Potassium-argon ages for the Honolulu 
Volcanics range from 0.9 to $0.03 \mathrm{Ma}$ (Clague and Dalrymple, 1987).

\section{GEOHYDROLOGY OF THE WATER-BEARING DEPOSITS}

The origin, mode of emplacement, texture, and composition of the rocks of Oahu determine their ability to store and transmit water. This section describes the geologic characteristics and hydraulic properties of the rocks as related to their origin and evolution.

\section{VOLCANIC ROCKS AND DEPOSITS}

Most Hawaiian volcanic rocks have similar basaltic composition, but their mode of emplacement caused a variety of geologic characteristics that govern their hydraulic properties. For this discussion, the volcanic rocks are divided into four groups: (1) lava flows, (2) dikes, (3) pyroclastic deposits, and (4) saprolite and weathered basalt. Each of these groups of rocks have markedly different geologic characteristics and hydraulic properties.

\section{LAVA FLOWS}

Stratified sequences of thin-bedded lava flows form the most productive aquifers in Hawaii. Lava flows on Oahu, as well as the other islands of Hawaii, are mainly of two textural types: (1) pahoehoe, which has a smoothly undulating surface; and (2) aa, which has a surface of coarse rubble and an interior of massive rock. Pahoehoe flows are formed by basaltic lavas that are fluid, flow rapidly, and tend to spread out. Most pahoehoe flows are thin, contain vesicles of various sizes, and are cracked and collapsed in places. Ponding of pahoehoe lava in depressions or on gentle slopes can result in thick accumulations of massive pahoehoe. Lateral permeability elements in pahoehoe include drained lava tubes and interflow voids (small depressions in the irregular upper surface of a lava flow that are not filled in by the viscous lava of the subsequent flow). Vertical permeability elements in pahoehoe in clude cooling joints; collapse features; skylights or holes in the roof of large lava tubes; and large, open cracks where lava is pushed up into humps and pressure ridges.

Pahoehoe lava commonly grades into aa lava with increasing distance from the eruptive vent. Aa flows are typified by a central core of massive rock several feet to tens of feet thick with layers of coarse, fragmental rock above and below. As the flowing aa lava cools and becomes more viscous, the hardened crust on top of the flow breaks up into angular, scoriaceous rubble known as aa clinker or flow-top breccia. Beneath the clinker, a core of viscous, incandescent lava continues to spread, carrying along the sheath of clinker like a tractor tread. As the flow advances, clinker and blocks of the massive core spall off and cascade down the front of the flow and are overridden by it. Subsequent cooling and volumetric contraction of the core result in well-developed joints. Aa clinker forms laterally extensive sheets of high-permeability material analogous to coarse, clean gravel.

\section{DIKES}

Dikes are thin sheets of massive intrusive rock that originates as intrusions of magma. Many dikes never reach land surface, but those that do typically feed elongate fissure eruptions, or "curtains of fire." Most dikes are no thicker than several feet and may extend thousands of feet vertically and several miles laterally. Where dikes intrude lava flows, they inhibit groundwater flow principally in the direction normal to the plane of the dike. Dike complexes are areas where dikes occur in large numbers and intersect at various angles forming small compartments and lowering overall rock porosity and permeability (Takasaki and Mink, 1985). Marginal dike zones are areas where dikes are subparallel and widely scattered. Dikes in these zones impound water within large compartments of more permeable lavas and direct ground-water flow parallel to the general trend of the dikes (Hirashima, 1962; Takasaki, 1971).

\section{PYROCLASTIC DEPOSITS}

Pyroclastic deposits include ash, cinder, and spatter. They are essentially granular, with porosity and permeability similar to that of granular sediments with a similar grain size and degree of sorting. Ash, being fine grained, is less permeable than coarse pyroclastic deposits such as cinder and spatter. The permeability of ash may be reduced further by weathering or by compaction to tuff. Weathered ash beds can act as thin confining units within lava sequences.

\section{SAPROLITE AND WEATHERED BASALT}

Weathering of basaltic rocks in the humid, subtropical climate of Oahu alters igneous minerals to clays and oxides and reduces the permeability of the parent rock. Weathered surficial materials promote runoff and impede the infiltration of water and anthropogenic contaminants to deeper aquifers. Exposed weathering profiles on Oahu typically include inches to feet of soil underlain by several feet to several tens of feet of saprolite, a soft, clay-rich, thoroughly decomposed rock that 
has retained textural features of the parent rock. In outcrops, saprolite commonly has a friable texture with extensive networks of joints forming small, blocky aggregates. In basaltic saprolite, diverse parent textures and a variable degree of weathering impart a heterogeneous permeability with preferential avenues of water movement and retention. Saprolite typically is less than $100 \mathrm{ft}$ thick in areas where precipitation is less than 50 in/yr and about 100 to $300 \mathrm{ft}$ thick where precipitation is greater than $50 \mathrm{in} / \mathrm{yr}$.

\section{HYDRAULIC PROPERTIES OF THE VOLCANIC ROCKS}

Estimates of aquifer properties on Oahu have been made by several methods: laboratory measurements on rock samples; local-scale aquifer tests in which drawdown is measured in a pumped well or in one or more observation wells at short distances from the pumped well; regional-scale aquifer tests in which one or more wells are pumped and area-wide drawdowns are observed; and by calibration of regional numerical models of ground-water flow.

The most commonly estimated properties have been hydraulic conductivity and transmissivity. Fewer estimates are available for storage coefficient, specific yield, bulk porosity, or effective porosity. Specific storage and aquifer compressibility have been reported in only a few instances. Generalized hydraulic conductivities of the geologic deposits of Oahu are given in table 2.

Most estimates of aquifer hydraulic properties on Oahu have been derived from aquifer tests at various field scales. Results from these tests, selected mainly from published reports, are given in table 3 . The thickness of the volcanic-rock aquifers of Oahu is not known, but probably is at least several thousand feet. This has important implications for estimates of hydraulic con- ductivity and transmissivity derived from aquifer tests. Transmissivity is a function of hydraulic conductivity and aquifer thickness, and is given by

where:

$$
T=K b \text {, }
$$

$T$ is transmissivity, in feet squared per day; $K$ is hydraulic conductivity, in feet per day; and $b$ is aquifer thickness, in feet.

\begin{tabular}{|c|c|}
\hline Geologic deposit & $\begin{array}{l}\text { Hydraulic conductivity } \\
\text { (ft/d) }\end{array}$ \\
\hline \multicolumn{2}{|l|}{ Volcanic rocks } \\
\hline \multicolumn{2}{|l|}{ Waianae Volcanics } \\
\hline Dike-free lava & $500-5,000$ \\
\hline Dike complex & $1-500$ \\
\hline Breccia & $1-100$ \\
\hline \multicolumn{2}{|l|}{ Koolau Basalt } \\
\hline Dike-free lava & $500-5,000$ \\
\hline Dike complex & $1-500$ \\
\hline Breccia & $1-100$ \\
\hline \multicolumn{2}{|l|}{ Honolulu Volcanics } \\
\hline Lava flow & $1-500$ \\
\hline Cinder & $1-500$ \\
\hline Tuff & $1-100$ \\
\hline Saprolite & $<1$ \\
\hline \multicolumn{2}{|l|}{ Sedimentary rocks } \\
\hline Coral & $100-20,000$ \\
\hline Sand dunes & $1-500$ \\
\hline Sand & $1-1,000$ \\
\hline Alluvium & $1-500$ \\
\hline
\end{tabular}

TABLE 3.-Hydraulic properties of dike-free lava flows estimated from aquifer tests, island of Oahu [Summarized from Hunt and Nichols, in press; $\mathrm{ft}^{2} / \mathrm{d}$, foot squared per day; ft/d, foot per day; - , no data]

\begin{tabular}{|c|c|c|c|c|}
\hline Investigator & $\begin{array}{c}\text { Transmissivity } \\
(\mathrm{ft} / \mathrm{d}) \\
\left(\times 10^{6}\right)\end{array}$ & $\begin{array}{c}\text { Hydraulic } \\
\text { conductivity } \\
(\mathrm{ft} / \mathrm{d})\end{array}$ & $\begin{array}{l}\text { Storage } \\
\text { coefficient } \\
\left(\times 10^{-2}\right)\end{array}$ & Method of analysis \\
\hline Wentworth, 1938 & & $1,800-3,500$ & & Thiem, 1906 \\
\hline Eyre and others, 1986 & & $68-960$ & & Hemispherical flow equation, Bear, 1979, p. 345 \\
\hline Visher and Mink, 1964 & $0.57-0.61$ & & $4.0-6.0$ & Theis, 1935; Ferris and others, 1962 \\
\hline Mink, 1980 & $0.93-2.70$ & 1,600 & $1.4-5.9$ & Theis, 1935; Ferris and others, 1962 \\
\hline Mink, 1980 & $1.40-2.60$ & 1,600 & $2.0-14.0$ & Jacob, 1946 \\
\hline Takasaki and others, 1969 & $0.19-0.54$ & & & Theis, 1935; Ferris and others, 1962 \\
\hline Rosenau and others, 1971 & $2.00-8.40$ & & & \\
\hline Todd and Meyer, 1971 & 0.55 & 1,800 & & Theis, 1935; Ferris and others, 1962 \\
\hline Williams and Soroos, 1973 & $0.25-0.47$ & & $0.78-2.8$ & Theis, 1935; Ferris and others, 1962 \\
\hline Williams and Soroos, 1973 & $0.26-0.51$ & & $0.77-2.0$ & Jacob, 1946 \\
\hline Williams and Soroos, 1973 & $0.43-0.90$ & $240-820$ & $4.70-19.0$ & Hantush, 1960 \\
\hline Williams and Soroos, 1973 & $0.37-0.96$ & & & Thiem, 1906 \\
\hline
\end{tabular}


Hydraulic conductivity likely decreases with depth because of compaction and may decrease sharply at depth where there is a transition from subaerially erupted lavas to submarine lavas.

Numerous estimates of hydraulic conductivity and transmissivity have been made for the Waianae Volcanics and Koolau Basalt. However, the unknown aquifer thickness and the partial penetration of wells introduce ambiguity to these estimates. A number of investigators have equated aquifer thickness to the thickness of freshwater flow or the zone of effective inflow to the well. Others have assumed it is equal to the thickness of the freshwater lens (see following section on occurrence of ground water). Although one or more of these approximations may be meaningful, their validity generally has not been supported by analysis, and, more importantly, they have not been applied consistently. Dividing a transmissivity estimate by the length of inflow to the pumped well, which in many instances is only $100 \mathrm{ft}$ or so, would yield a hydraulic conductivity as much as an order of magnitude greater than if the same transmissivity was divided by the freshwater lens thickness, which may be as much as $1,000 \mathrm{ft}$.

In cases of steady-state ground-water flow in a freshwater lens, it can be reasoned that aquifer thickness theoretically corresponds to the thickness of the freshwater lens because freshwater head gradients induce only freshwater flow and not flow in the underlying saltwater. An estimate of transmissivity based on the Thiem (1906) steady-flow equation is correct only if a steady state has been sufficiently approximated, if the aquifer is isotropic, and if a correction is made for partial penetration where mandated by the relations among aquifer thickness and the radial distance to and depth of the observation well. The validity of equating aquifer thickness to lens thickness is less certain under transient flow conditions applicable to Theis (1935) analysis. During the transient period some saltwater flow could be induced by upconing of the freshwatersaltwater interface.

Estimates of hydraulic conductivity for dike-free lava flows, based mostly on the solution of the Theis (1935) and Thiem (1906) equations, tend to fall within about one order of magnitude, from several hundred to several thousand feet per day. Mink and Lau (1980) suggested that a regional value for hydraulic conductivity of unweathered, flank lavas is in the range of 500 to 5,000 $\mathrm{ft} / \mathrm{d}$ with the most probable values centering around $2,000 \mathrm{ft} / \mathrm{d}$. Liu and others (1983) stated that hydraulic conductivity for basalt in the Pearl Harbor area is between 1,000 and $2,000 \mathrm{ft} / \mathrm{d}$. Hydraulic conductivity estimated by Soroos (1973) from 79 specific-capacity tests on Oahu ranged from 26 to $85,000 \mathrm{ft} / \mathrm{d}$ with a mean of about $3,400 \mathrm{ft} / \mathrm{d}$ and a median of about $840 \mathrm{ft} / \mathrm{d}$.
A small range of hydraulic conductivity has been applied to numerical models of ground-water flow on Oahu, most of which have been two-dimensional areal representations of horizontal freshwater flow. Areal models of southern and southeastern Oahu were calibrated using hydraulic conductivity values of 500 to 4,500 ft/d (Liu and others, 1983; Eyre and others, 1986; Eyre and Nichols, in press). These values were determined by model calibration using repetitive, trial-anderror methods. Souza and Voss (1987) simulated miscible, density-dependent, freshwater-saltwater flow and solute transport in vertical cross section in southern Oahu. They used values of $1,500 \mathrm{ft} / \mathrm{d}$ for horizontal hydraulic conductivity and $7.5 \mathrm{ft} / \mathrm{d}$ for vertical hydraulic conductivity.

Layered and channeled lavas have a hydraulic conductivity that is anisotropic in three dimensions with its greatest principal axis in the longitudinal lava-flow direction, intermediate principal axis in the direction transverse to the direction of the lava flow, and least principal axis normal to the plane of the lava flow. Only a few estimates of hydraulic anisotropy have been made for Hawaiian lava aquifers. Eyre and Nichols (in press) specified anisotropic transmissivity on the order of 3:1 to reproduce the observed areal head distribution in a numerical analysis of ground-water flow in southern Oahu. The maximum principal axis was aligned parallel to the longitudinal direction of lava flows. Burnham and others (1977, p. 17) presumed horizontal:vertical anisotropy ratios of 10:1 and 100:1 in a numerical analysis of wastewater injection on the island of Maui, but suggested that a regional ratio may be closer to $5: 1$. Souza and Voss (1987) estimated a 200:1 horizontal:vertical anisotropy ratio in a numerical analysis of flow in the Pearl Harbor ground-water area.

Total porosity is the bulk volume of material occupied by voids, whether isolated or connected. In a layered sequence of lava flows, it is common for several types of porosity to be present as follows:

1. Vesicular-small gas vesicles that form in molten lava;

2. Fracture-joints, cracks, and separations between individual lava flows;

3. Intergranular-void space in fragmental rock (including cinder, rubble, and clinker) that is analogous to the porosity of clean, coarse gravel; and

4. Conduit-large openings such as lava tubes and interflow voids that take forms similar to solution conduits in limestone.

Vesicular porosity is a conspicuous element of bulk porosity, but commonly the vesicles are poorly connected and contribute little to effective porosity. Fracture and intergranular porosity form a pervasive network of small openings that facilitates ground-water flow. Con- 
duits provide avenues for highly channelized flow similar to that found in carbonate aquifers (White, 1969).

Estimates of the total porosity of various volcanic rocks on Oahu have been made by laboratory analysis of rock samples, by borehole photographic logging, and by gravity profiling in underground tunnels. For Koolau Basalt, Wentworth (1938) found porosities ranging from 5 to 51 percent, with a median value of about 43 percent. However, the greater part of the space in the vesicles of these flows is not interconnected and only to a slight extent does it contribute to the effective storage and movement of water in the formation (Wentworth, 1938, p. 175).

Porosity was reported to be 5 and 10 percent for two samples of massive Koolau dike rock, and porosities of massive basalt of the Honolulu Volcanics were 16 percent or less and typically less than 10 percent. Ishizaki and others (1967) reported laboratory values of porosity of about 8 to 10 percent for massive aa core (Koolau Basalt) and about 50 percent for aa clinker. Peterson and Seghal (1974, p. 8), using borehole photographic logs, estimated intergranular and secondary porosity of basaltic lavas ranging from less than 5 percent in dense flows to as much as 50 percent in some aa clinker zones. All of these estimates are of total porosity, which includes the unconnected vesicular component of porosity. Values of effective porosity may be lower by as much as a factor of 2 to 5 .

Specific yield represents the volume of water an unconfined aquifer releases from storage per unit surface area of aquifer per unit decline in the unconfined water level. It represents an actual dewatering of the pores of the aquifer material under gravity drainage. The storage coefficient of a confined aquifer is the volume of water released from storage per unit surface area of the aquifer per unit decline in hydraulic head and is given by

where:

$$
S=S s b,
$$

$S$ is the storage coefficient, dimensionless;

Ss is specific storage, dimensionless; and

$b$ is aquifer thickness, in feet.

Water released from storage in a confined aquifer represents water released by the expansion of water and the compaction of the aquifer caused by a reduction of water pressure in the aquifer. Estimating a storage coefficient for confined basalt aquifers involves the same difficulty as estimating hydraulic conductivity because a value for aquifer thickness is required.

Estimates of specific yield range from about 1 to 20 percent with the exception of one value of 42 percent. Most of the values lie within a narrow range of about 5 to 10 percent. Estimates of confined storage coeffi- cient typically are somewhat higher than the range of $5 \times 10^{-3}$ to $5 \times 10^{-5}$ cited for confined aquifers by Freeze and Cherry (1979). Investigators commonly interpreted these larger values to indicate leaky, or semiconfined, conditions.

\section{SEDIMENTARY ROCKS AND DEPOSITS}

Sedimentary rocks on Oahu are of both marine and terrestrial origin and have wide ranges in composition, grain size, and degree of induration. Marine sedimentary rocks are mostly calcareous and include coral-algal reefs, coralline rubble and sand, and lagoonal sand and marl. Terrestrial sedimentary deposits include talus; colluvium, and alluvium; the sediment ranges in size from estuarine mud to boulders.

Marine sedimentary deposits are areally widespread, occupying the coastal plain and the lower reaches of coastal valleys. The largest volume of sediment occurs in stratified sequences beneath the coastal plain. This wedge of calcareous and volcanogenic sediment is known locally as caprock because it overlies and confines ground water in the underlying volcanic-rock aquifers. The confining property of the coastal sediment stems mainly from the presence of fine-grained mud and marls and from weathering of basalt-derived material.

Alluvial deposits generally are restricted to long, narrow valleys, commonly as poorly sorted mixtures of boulders, cobbles, gravel, and sand. Alluvium also forms deltas of silt and sand in estuaries at the mouths of streams. The alluvial deposits can be divided into younger alluvium, which is unconsolidated and unweathered, and older alluvium, which is wholly or partly consolidated and generally is severely weathered (Stearns and Vaksvik, 1935; Wentworth, 1951).

It is convenient to divide the sedimentary deposits into calcareous and noncalcareous deposits for a discussion of hydraulic properties. The permeability of calcareous rocks commonly is moderate to very high and results from primary depositional textures as well as from development of secondary porosity by solution. The most important water-bearing calcareous rocks are the uppermost units of the coastal sediments consisting of reef limestone, coralline rubble, and calcareous sand. These layers are productive aquifers and they supply significant quantities of fresh and brackish water to wells. Cavernous limestone and coarse coralline rubble are among the most permeable rocks on Oahu and commonly are more permeable than the basaltic lavas. Hydraulic conductivities of several thousand feet per day are believed to be representative, and many estimates from aquifer tests and tidal analyses exceed 10,000 ft/d (Dale, 1974; Williams and Liu, 1975; Khan, 1981; Oberdorfer and Peterson, 1985). In contrast, the 
noncalcareous deposits tend to be less permeable, mainly because their basaltic composition results in rapid and thorough weathering that increases clay content. The most common noncalcareous sedimentary deposit on Oahu is alluvium of generally low permeability.

\section{OCCURRENCE OF GROUND WATER}

\section{BASAL GROUND WATER}

The most extensive bodies of freshwater on Oahu occur as basal ground water. Basal ground water refers to "the great body of water that lies below the main water table" (Meinzer, 1930). The main water table is that level below which all permeable rocks are saturated. The term "basal ground water" was introduced to distinguish this water from perched water. The typical example of basal ground water is a lens of freshwater that floats on saltwater within an aquifer, with the freshwater head in the aquifer near sea level (fig. 8). This type of freshwater occurrence was recognized early in Hawaii by Lindgren (1903). The term "basal ground water" is not used widely in hydrology except in Hawaii or other islands by workers familiar with the groundwater literature of Hawaii. Synonymous terms for basal ground water include "freshwater lens," "basal lens," and "Ghyben-Herzberg lens" (Hunt and others, 1988).

Basal ground water occurs in both volcanic-rock aquifers and aquifers in the sedimentary deposits on Oahu under confined and unconfined conditions. The thickness of the freshwater lens depends on recharge, aquifer permeability, and the presence or absence of confinement. Recharge to a given basal-water body may occur by direct infiltration of precipitation or streamflow and by ground-water inflow from upgradient ground water.

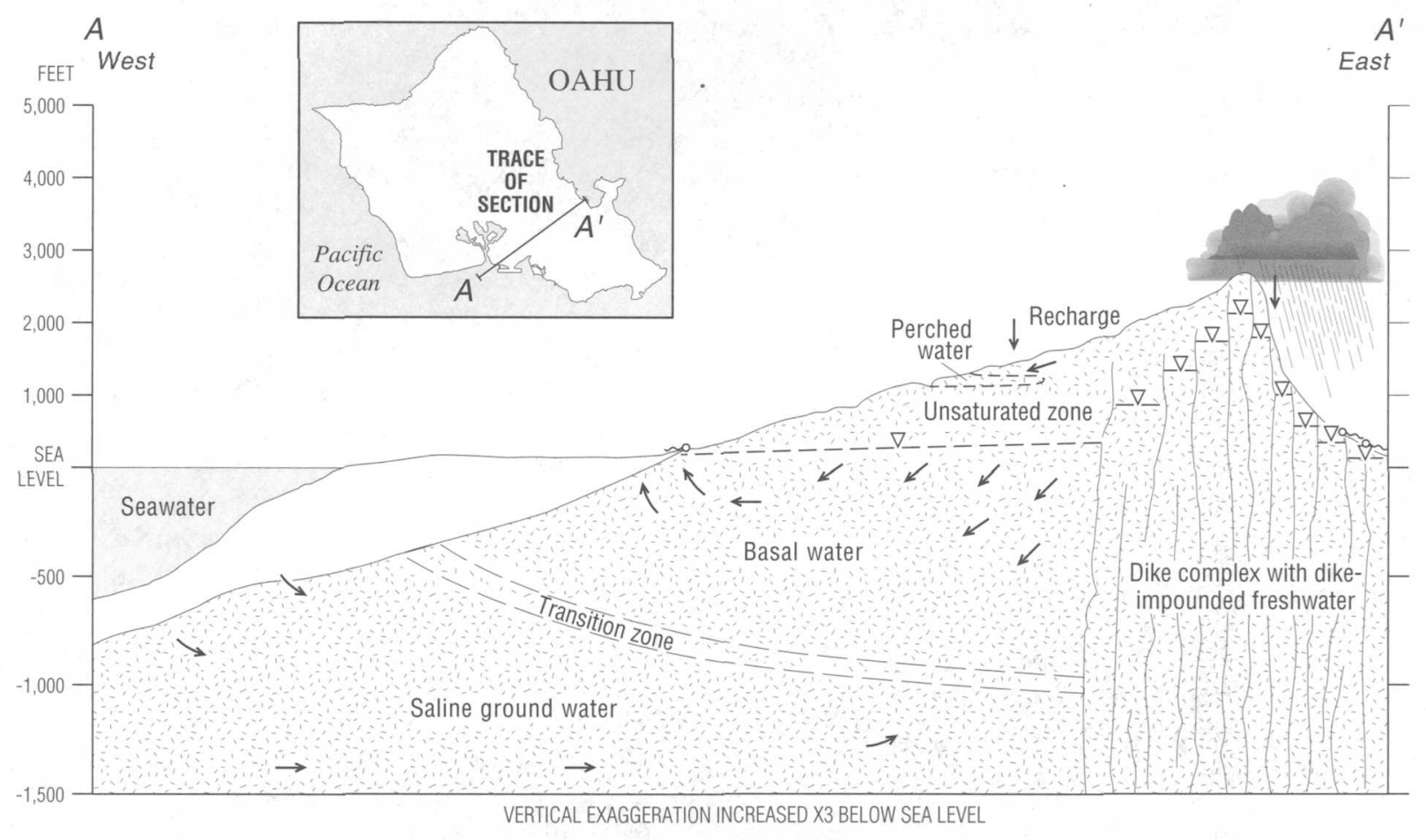

EXPLANATION

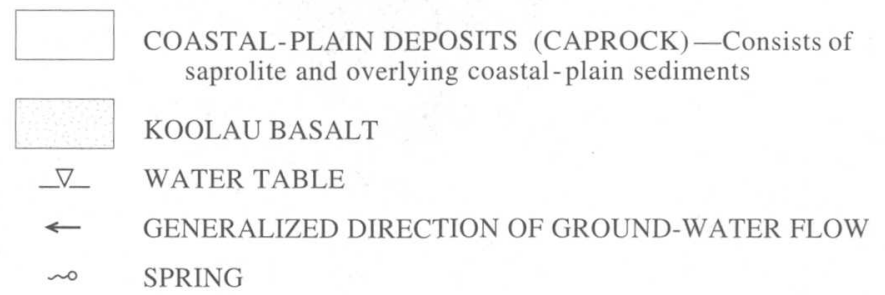

Figure 8.-Modes of ground-water occurence on the island of Oahu. 
The water table, or potentiometric surface, of a Hawaiian basal-water lens typically is gently sloping and only several feet to several tens of feet above sea level. However, the largest volume of freshwater lies below sea level. This results from the buoyant displacement of the underlying saltwater by freshwater and is governed by the difference in their specific gravities. The depth of freshwater below sea level is equal to about $40 \mathrm{ft}$ for every foot of freshwater above sea level (the GhybenHerzberg relation). For a freshwater head of $5 \mathrm{ft}$ above sea level, there would be $200 \mathrm{ft}$ of freshwater below sea level and the freshwater lens would be $205 \mathrm{ft}$ thick. Wentworth (1939) reported determinations of freshwater and saltwater density in and around Oahu and proposed that a ratio closer to $38: 1$ would be more correct.

Basal water in the thick volcanic-rock sequences of Oahu exists as free-floating lenses underlain by saltwater. At the base of the lens, the transition zone of mixed freshwater and saltwater may range in thickness from tens of feet to hundreds of feet. Basal water in the volcanic rocks of Oahu is mostly unconfined, except near the coast where the aquifer may be overlain and confined by sedimentary caprock. In the absence of a confining unit near the coast, which impedes discharge of water to the sea, a comparatively thin basal-water body forms. The freshwater lens in this instance is no more than about $100 \mathrm{ft}$ thick, and freshwater discharges to the sea by diffuse sea-bottom seepage and at distinct submarine and shore line springs.

Where the volcanic-rock aquifer is overlain by caprock along the coast, ground water in the aquifer beneath the caprock is confined and a thicker basal-water lens forms. The hydraulic head in the aquifer is impounded to a level higher than it would be in the absence of confinement. Beneath the confining unit in the coastal zone, the freshwater would be properly referred to as confined basal water.

In a caprock-impounded basal-water lens, potentiometric levels in the confined coastal zone are several feet to several tens of feet above sea level. In the unconfined part of the aquifer, the water table rises inland at about 1 to $2 \mathrm{ft} / \mathrm{mi}$. Maximum inland freshwater heads in impounded basal lenses on Oahu typically are about 10 to $40 \mathrm{ft}$ above sea level with lens thicknesses about 40 times the head above sea level. The highest basal-water head measured on Oahu was $43.5 \mathrm{ft}$ above sea level in the Honolulu area in 1880 (Stearns and Vaksvik, 1938); this implies that the freshwater lens was more than $1,700 \mathrm{ft}$ thick at that time. Coastal discharge from an impounded lens is by measurable flow from prominent lowland springs near the inland edge of the sedimentary confining unit and by unmeasurable leakage through the confining unit.
Basal water in sedimentary rocks and deposits commonly is no more than $100 \mathrm{ft}$ thick, and the water levels are not more than several feet above sea level. Most basal water in sedimentary rocks is unconfined and resides in the uppermost aquifers of the coastal-plain sediments. Confining beds of clay or soil are common at the base of these aquifers, and freshwater may occupy the entire thickness of the aquifer in some areas, although these areas are laterally contiguous with areas of freely floating freshwater.

\section{HIGH-LEVEL GROUND WATER}

Ground water occurs under two principal conditions at high altitudes above sea level: dike-impounded and perched. Dike-impounded high-level ground water occurs dominantly in the rift zones of the Waianae and Koolau Volcanoes. Perched ground water occurs in the unsaturated zone where conditions are suitable. A large body of high-level ground water occurs in the Schofield. area of central Oahu that is different from either dikeimpounded or perched ground water.

\section{DIKE-IMPOUNDED GROUND WATER}

Steeply dipping volcanic dikes impound freshwater to great heights within the rift zones of the Waianae and Koolau Volcanoes. The dikes are barriers mainly to the lateral flow of ground water and impound water in compartments, or reservoirs, of permeable lavas (fig. 8). The term "dike-impounded water" evolved during the 1960's, replacing the earlier terms "dike-confined water" and "dike water." The term "dike-impounded water" is used to characterize any water that is enclosed or restrained laterally by dikes. Freshwater in dike-impounded reservoirs reaches altitudes of nearly $2,000 \mathrm{ft}$ above sea level in the rift zones of Oahu and is commonly higher than several hundred feet. Dike-impounded water contributes to streamflow where valleys intersect the impounded water table; it also moves downgradient into basal-water lenses.

\section{PERCHED GROUND WATER AND WATER IN THE UNSATURATED ZONE}

The unsaturated zone is several hundred feet thick throughout much of Oahu and may be more than 1,000 $\mathrm{ft}$ thick in places. This zone includes the layers of soil, saprolite, sediment, and rock that lie above the deepest water table. Within the unsaturated zone, perched water occurs in places where low permeability material impedes downward percolation enough to cause local saturation. Some of the largest bodies of perched water are associated with alluvium and rocks of the Honolulu Volcanics in valleys of the Honolulu area. 


\section{SCHOFIELD HIGH-LEVEL GROUND WATER}

A large body of high-level water occurs beneath the Schofield Plateau of central Oahu, and its occurrence and behavior do not resemble dike-impounded or perched types of high-level water. The Schofield highlevel water is impounded to a height of about 275 to 280 $\mathrm{ft}$ above sea level by regional subsurface geologic structures, probably dikes or weathered, buried volcanic ridges, or a combination of these. The water occurs mainly in permeable Koolau lavas that do not seem to be divided into small dike compartments except perhaps within the impounding structures themselves. On the basis of ground-water levels in wells, the potentiometric surface in the Koolau aquifer is considered to be continuous and very flat beneath much of the plateau.

\section{SALTWATER}

Rocks beneath the fresh ground water of Oahu are saturated with saltwater, which may occur in permeable subaerial lavas to depths of 6,000 to $10,000 \mathrm{ft}$ (the probable submergence of former subaerial lavas) and in less permeable submarine lavas at greater depths. The thickest known basal freshwater on Oahu extended to about $1,700 \mathrm{ft}$ below sea level. The maximum depth of dike-impounded freshwater is not known, but on the basis of observed heads of a thousand feet or more in the rift zones, it is likely more than the thickest basal water.

\section{AQUIFER SYSTEM OF OAHU}

Historical aquifer nomenclature for Oahu evolved without a consistent approach, resulting in a mixture of named and unnamed aquifer references. Examples of unnamed references are "the highly permeable volcanicrock aquifer" and "the basal aquifers of the Honolulu area." References to named aquifers have implied correspondence to rock-stratigraphic units, such as the "Waianae aquifer" and "Koolau aquifer," or have invoked other locality names, such as "the Pearl Harbor aquifer." In addition to aquifers, other geohydrologic entities have been delineated on the basis of structural boundaries and modes of ground-water occurrence. Various workers have delineated "artesian areas," "isopiestic areas," and "ground-water bodies," for example the "Honolulu isopiestic areas" or the "Waialua basal-water body." Mink and Sumida (1984), noting the lack of an orderly procedure for naming aquifers in the Hawaiian islands, proposed a systematic aquifer classification for the major islands (later revised for Oahu by Mink and Lau, 1990). The RASA study defined an aquifer system for Oahu that is based on stratigraphy and limited in lateral extent and hydraulic continuity by nonconfor- mable and steeply dipping geohydrologic barriers. The result is a regional aquifer system composed of two principal aquifers that are subdivided into well-defined areas by geohydrologic barriers (fig. 9).

\section{PRINCIPAL AQUIFERS}

The Waianae aquifer in the Waianae Volcanics and the Koolau aquifer in the Koolau Basalt are the two principal volcanic-rock aquifers on Oahu (fig. 4). They are composed mainly of thick sequences of permeable, thinbedded lavas. The two aquifers combine to form a layered aquifer system throughout central Oahu, where the Koolau aquifer overlies the Waianae aquifer. They are separated by a regional confining unit, the Waianae confining unit, formed along the Waianae-Koolau unconformity, which marks the eroded and weathered surface of the Waianae Volcano that was buried by younger Koolau lavas.

In some coastal areas, caprock overlies and confines the Waianae and Koolau aquifers, impeding freshwater discharge and impounding basal water to great thicknesses. Beneath the caprock, weathered saprolite at the top of the volcanic formations also contributes to the confinement of water in the underlying volcanic-rock aquifers.

\section{GEOHYDROLOGIC BARRIERS}

The areal hydraulic continuity of the aquifers of Oahu is interrupted in many places by steeply dipping, geohydrologic barriers (fig. $9 \mathrm{C}$ ) that cut across the layered lavas at high angles. There are two types of barriers: those of structural origin, which are mainly intrusive rocks, but also may include other types of massive rock, such as ponded lavas; and those of surficial origin, which are mainly valley-fill deposits, but also may include weathered geologic material. These barriers impede and divert ground-water flow.

Structural barriers are deep-rooted features including rift-zone intrusives, stray dikes that lie somewhat apart from well-defined rift zones, and two extensive impounding structures in the Schofield Plateau of central Oahu. Structural barriers commonly cause large and abrupt head discontinuities ranging from tens of feet to hundreds of feet. In the Schofield area and the rift zones, these barriers impound ground water from several hundred to as much as $1,600 \mathrm{ft}$ above sea level (fig. $10)$.

Surficial barriers result from processes of erosion, sedimentation, and weathering at the surface of the lava flows. The most common surficial barriers are sedimentary valley-fill deposits and underlying saprolite and weathered volcanic rock. The valley-fill barriers are superficial, or partially penetrating barriers that im- 

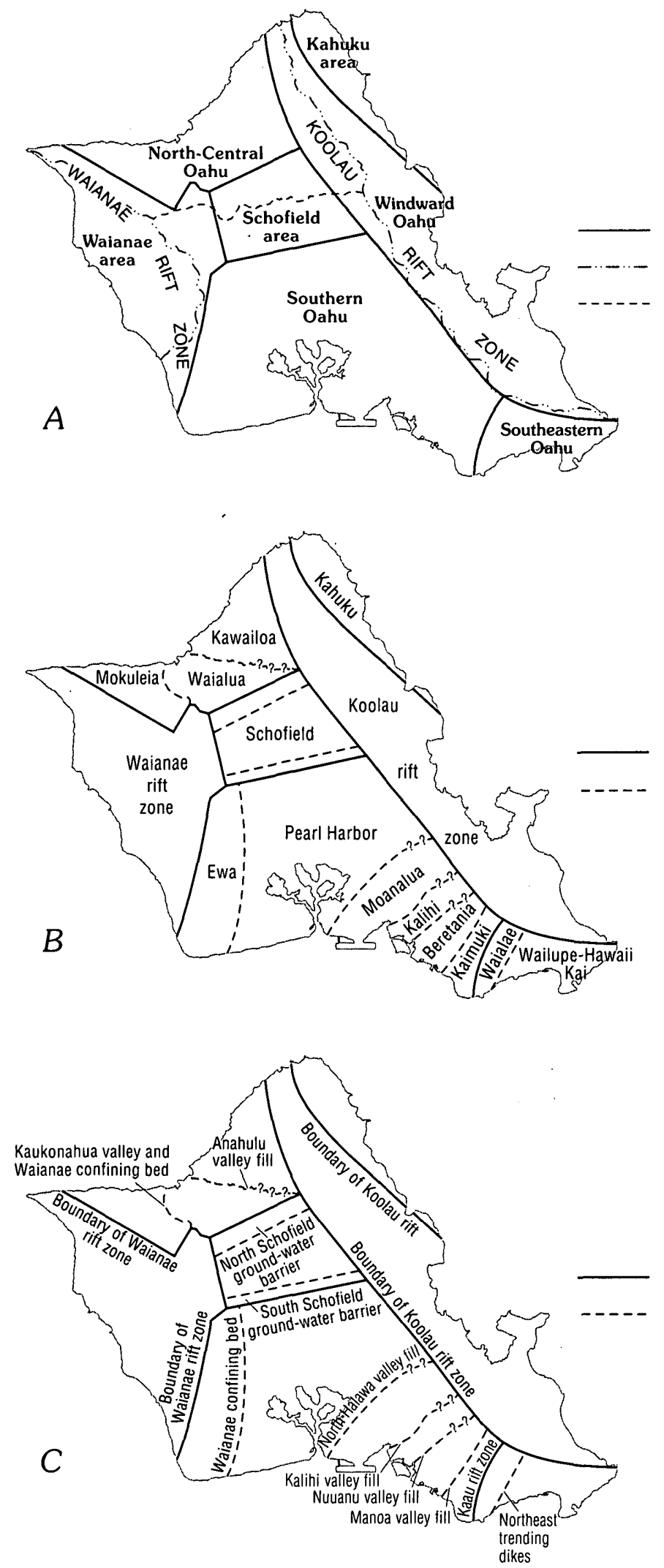

\section{EXPLANATION}

MAJOR GEOHYDROLOGIC BOUNDARY

TOPOGRAPHIC DIVIDE

DISTRICT BOUNDARY

\section{EXPLANATION}

MAJOR GEOHYDROLOGIC BOUNDARY SUBORDINATE GEOHYDROLOGIC BOUNDARY Queried where uncertain
EXPLANATION

MAJOR GEOHYDROLOGIC BOUNDARY

SUBORDINATE GEOHYDROLOGIC BOUNDARY -

Queried where uncertain

FIGURE 9.-Ground-water areas and geohydrologic barriers, island of Oahu. $A$, Major ground-water areas. $B$, Subordinate ground-water areas. $C$, Geohydrologic barriers. 
pede ground-water flow in shallow parts of the volcanicrock aquifers.

The Schofield area in central Oahu is bounded on the north and south by geohydrologic barriers of an undetermined type, referred to as ground-water dams by Dale and Takasaki (1976). These barriers may be zones of intrusive rock, but they also seem to be associated with an erosional surface on Waianae Volcanics now buried by Koolau Basalt. These barriers may be a composite of dike-intruded rock, buried erosional surface, and massive lavas.

\section{GROUND-WATER AREAS OF OAHU}

The island of Oahu has been divided into seven major ground-water areas (fig. 9A) that are delineated by deep-seated structural geohydrologic barriers. These areas are the Kahuku area, the Koolau and Waianae rift zones, north-central, southeastern, and southern Oahu, and the Schofield area. Hydraulic continuity within these seven areas generally is high, and the potentiometric surface is smoothly continuous except in rift zones where dikes cause numerous local discontinuities. Some of these areas, notably southern Oahu and northcentral Oahu, are further subdivided by subordinate surficial geohydrologic barriers. The locality names of the ground-water areas used in this report are those that have been cited most frequently in previous reports.

The Koolau rift zone along the eastern side of the island and the Waianae rift zone to the west constitute two of the major ground-water areas (fig. 9A). Both of these areas contain dike-impounded ground water. The boundaries of the rift zones are slightly modified after Dale and Takasaki (1976) and Takasaki and Mink (1985).

The north-central Oahu area (fig. $9 A$ ), which contains a basal lens of freshwater with some confinement along the coast, is bounded on the east by the Koolau rift zone, on the south by the north Schofield ground-water barrier (fig. $9 \mathrm{C}$ ), on the west by the Waianae rift zone, and on the north by the sea. The area is divided into three smaller ground-water areas, the Mokuleia, Waialua, and Kawailoa areas, each of which contains a basal freshwater lens. The Waianae confining unit was considered by Dale (1978) to be the principal geohydrologic barrier separating the Mokuleia and Waialua areas, but valley-fill sediments in the Kaukonahua Valley (fig. $9 B, C)$ also may inhibit the lateral flow of ground water between the two areas. Valley-fill sediments in the Anahulu Valley (fig. $9 B, C$ ) form a barrier between the Waialua area and the Kawailoa area near the coast (Dale, 1978), although the barrier effect may diminish inland as the depth of valley incision decreases.
The Schofield ground-water area (fig. 9A) encompasses much of the Schofield Plateau of central Oahu. The area is bounded on the east and west by the Koolau and Waianae rift zones and on the north and south by the north and south Schofield ground-water barriers. Within this area, ground water is impounded to altitudes of about 275 to $280 \mathrm{ft}$ above sea level (fig. 10). The occurrence of ground water in this area is considered to be a high-level type, but it is not dike impounded in the sense of ground water that occurs in the rift zones.

The southern Oahu area is bounded on the east by the Koolau and Kaau rift zones (fig. $9 \mathrm{C}$ ), on the north by the south Schofield ground-water barrier, on the west by the Waianae rift zone, and on the south by the sea. The area has been divided into six smaller ground-water areas (fig. 9B), mostly by valley-fill type barriers. Each of the areas contains a basal freshwater lens. The Ewa area on the west is underlain by the Waianae Volcanics and originally was identified as a separate major groundwater area based on differences in ground-water levels with the adjacent Pearl Harbor area. The Pearl Harbor, Moanalua, Kalihi, Beretania, and Kaimuki areas of southern Oahu (fig. $9 B$ ) are underlain by Koolau Basalt and are separated by valley-fill barriers. As in northcentral Oahu, the efficiency of the barriers may diminish significantly inland from the coast with increasing altitude and decreasing penetration of the valleys into the underlying basalt. The boundary between the Pearl Harbor and Moanalua areas has been revised from South Halawa Valley to North Halawa Valley (Eyre and Nichols, in press).

The southeastern Oahu area is divided into two smaller ground-water areas (fig. $9 A, B$ ), both of which contain a basal freshwater lens. The major area is bounded on the north by the Koolau rift zone and on the west by the Kaau rift zone (fig. 9C). The Waialae and Wailupe-Hawaii Kai ground-water areas (fig. $9 B$ ) are separated by a poorly defined zone of northeast-trending dikes (Takasaki and Mink, 1982). Numerous dikes within the Kaau rift zone (fig. $9 C$ ) create an effective hydraulic separation between the Waialae area and the Kaimuki area of southern Oahu (fig. $9 B$ ) to the west (Takasaki and Mink, 1982).

Along the northeast coast of windward Oahu is the Kahuku ground-water area (fig. 9A). Ground water occurs here as a basal freshwater lens. Valleys in the Kahuku area are not as deep as those of the Honolulu area and are more comparable to the shallower gulches of the Pearl Harbor area and perhaps to Anahulu Valley. The southernmost valleys likely compartmentalize the aquifer considerably, but there are few wells there and separate ground-water areas have not been distinguished. 


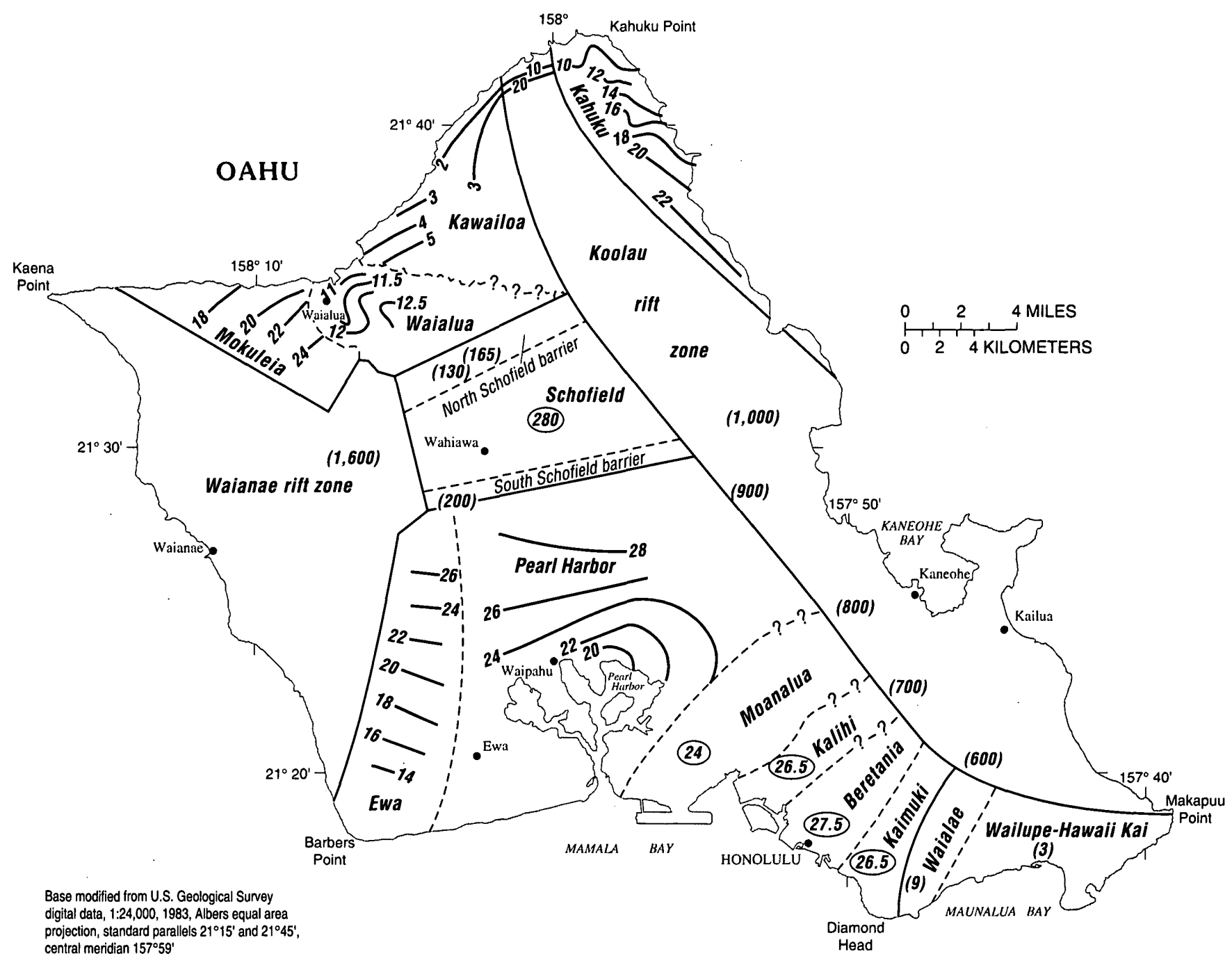

EXPLANATION

Ewa SUBORDINATE GROUND-WATER AREA-Annoted with mixed case

MAJOR GEOHYDROLOGIC BOUNDARY

SUBORDINATE GEOHYDROLOGIC BOUNDARY Queried where uncertain

24 WATER-LEVEL CONTOUR-Shows altitude of water level in the mid 1950 's. Contour interval, in feet, is variable. Datum is mean sea level

(165) POINT OBSERVATION OF ALTITUDE OF WATER LEVEL IN THE MID 1950'S, IN FEET ABOVE MEAN SEA LEVEL

(24) REPRESENTATIVE MID 1950'S WATER LEVEL WHERE WATER TABLE IS TOO FLAT TO BE CONTOURED, IN FEET ABOVE MEAN SEA LEVEL

FIGURE 10.-Ground-water areas and potentiometric surface (mid-1950's) in the principal volcanic aquifers, island of Oahu (compiled from previous studies by the U.S. Geological Survey). 


\section{GROUND-WATER FLOW SYSTEMS OF OAHU}

The aquifers of Oahu contain two fundamental ground-water flow systems: shallow freshwater and deeper saltwater. Fresh ground water floats on underlying saltwater in a condition of buoyant displacement. Most freshwater flow is driven by gravity from inland recharge areas at higher altitudes to discharge areas at lower altitudes near the coast. Remnant volcanic heat may drive geothermal convection of freshwater in the rift zones. Saltwater flow is driven by changes in freshwater volume and in sea level, and by dispersive and geothermal convection.

\section{FRESHWATER FLOW SYSTEM}

There are five fresh ground-water flow systems: (1) the eastern Oahu flow system; a central Oahu flow system, which is divided into (2) the northern and (3) southern Oahu flow systems; (4) the western Oahu flow system; and (5) the southeastern Oahu flow system (fig. 11). Meteoric freshwater flow diverges from ground-water divides that lie somewhere within the Waianae and Koolau rift zones forming an interior flow system in central Oahu and exterior flow systems in western (Waianae area), eastern (windward), and southeastern Oahu. The exact locations of the ground-water divides are not known, but following a common convention, they are shown as coinciding with topographic divides for diagrammatic purposes. The ground-water divides may move in response to transient hydrologic stresses.

Ground water in each flow system moves through one or more ground-water areas within the principal volcanic-rock aquifers, as well as through any sediments on the coastal plain. Water flows across geohydrologic barriers from areas of higher head to areas of lower head in the volcanic-rock aquifers (fig. 10), then into overlying sediments, and ultimately to the sea.

Dike-impounded ground water in the high-precipitation areas of the mountains in the Koolau and Waianae rift zones is the origin of the regional freshwater flow systems of Oahu. The topographic divide in the Koolau rift zone is arbitrarily shown as the boundary between the eastern Oahu flow system, which includes all of windward Oahu, and the flow systems of northern, southern, and southeastern Oahu. Similarly, the topographic divide along the crest of the Waianae Range in the Waianae rift zone is shown as the boundary between the western Oahu ground-water flow system, which encompasses the Waianae area, and the northern and southern Oahu flow systems. The actual locations of these ground-water flow-system divides are not known.

Ground water in the eastern Oahu flow system, on the windward side of the Koolau Range, moves down-gra- dient in the rift zone from near the crest of the range to the sea. The entire breadth of the northern part of the rift zone is above the potentiometric surface and is a recharge area. In the central and southern parts of the flow system where the rift zone is more dissected by erosion, the potentiometric surface is at or near land surface, except near the crest of the range, causing ground-water discharge, high evapotranspiration, and rejection of recharge.

The western Oahu ground-water flow system is in the Waianae rift zone west of the crest of the Waianae Range and is coincident with the Waianae area of previous investigations (Zones, 1963; Takasaki, 1971). Ground water in this system generally flows west from near the crest of the Waianae Range to the sea. The west slope of the Waianae Range is deeply dissected, and, within the shallow depths penetrated by wells, the Waianae aquifer is present only as narrow interfluvial ridges that are separated by valley-fill sediments in intervening valleys that may be incised to at least 1,200 $\mathrm{ft}$ below sea level. The combination of dikes in the rift zone and thick valley fill results in a compartmented flow system in which the volcanic-rock aquifer has little regional hydraulic continuity.

The northern and southern Oahu ground-water flow systems in central Oahu (fig. 11) contain large quantities of basal ground water. Early ground-water development in both flow systems was primarily from freeflowing artesian wells open to confined parts of the aquifers near the coast and from springs near the basalt-caprock contact. Pumpage historically has been large in southern Oahu and in the Waialua area of northern Oahu (fig. 9B), with agricultural pumpage constituting a large part of total pumpage. Southern Oahu is the most heavily developed area of Oahu and serves as the island's principal source of freshwater. This area is the most intensely studied area of the Hawaiian islands, and the Honolulu and Pearl Harbor areas have received particularly detailed attention since the early 1900's. Much of the present knowledge of ground-water hydrology in Hawaii has come from the study of southern Oahu.

The northern and southern Oahu flow systems encompass the greatest extent of the island. Flow originates in the high-precipitation areas of the Waianae and Koolau rift zone mountains and continues downgradient into the ground-water areas of the central Oahu plateau, diverging to the north and south somewhere within the Schofield area. Ground-water flow occurs as underflow from the rift zones into the Schofield area. Ground water then flows out of the Schofield area as underflow to the north and south from a poorly defined ground-water divide arbitrarily shown here as coinciding with the Waialua-Wahiawa District boundary. The 
underflow is controlled by the north and south Schofield ground-water barriers.

Extensive caprock along the coast of both southern and northern Oahu strongly affects ground-water flow. By confining water in the Waianae and Koolau aquifers, the caprock impounds basal freshwater to thicknesses of 1,000 ft or more in southern Oahu and to thicknesses of $500 \mathrm{ft}$ in the Mokuleia area of northern Oahu.
Ground-water discharge from the northern and southern Oahu flow systems under natural conditions is near the inland, thinnest margin of the caprock as spring flow and as leakage through the caprock. Much of the discharge may be, in effect, overflow at the top of the caprock. The Pearl Harbor springs (fig. 12) appear to be largely of this nature (Visher and Mink, 1964).

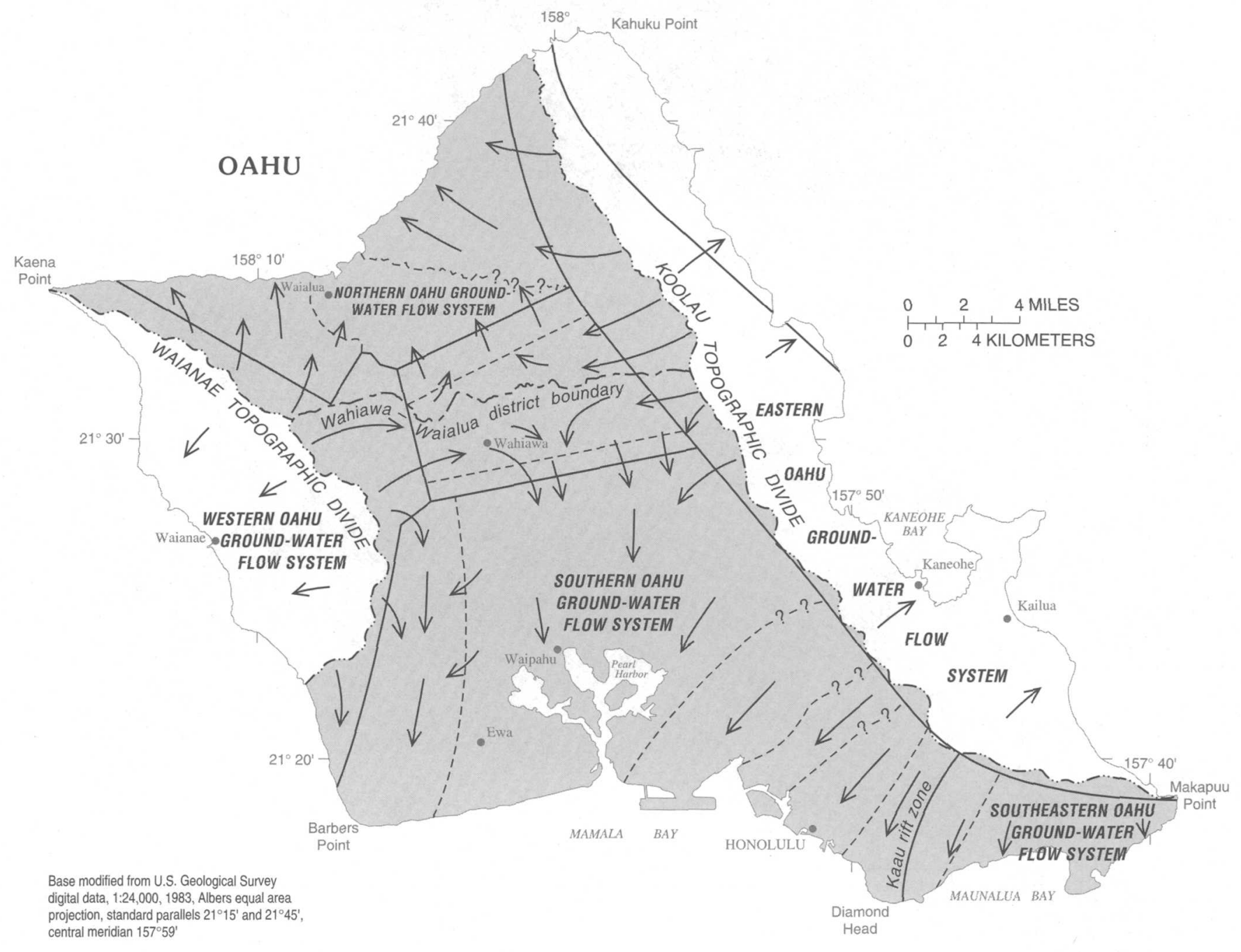

EXPLANATION

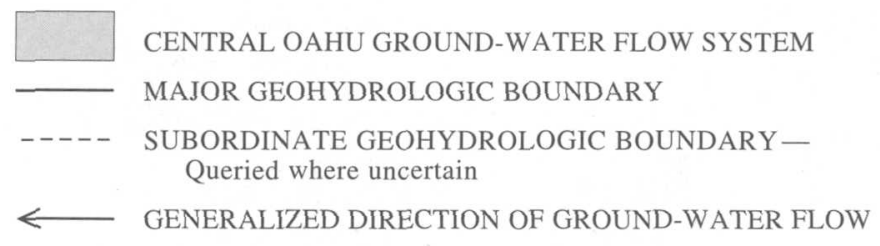

FiguRE 11.-Ground-water flow systems and the major areas of the central flow system, island of Oahu. 
The smallest regional freshwater flow system on Oahu lies at the southeastern end of the Koolau Range where basal water occurs in the Koolau aquifer (fig. 11). Inflow to the Waialae and Wailupe-Hawaii Kai areas of southeastern Oahu is by infiltration of precipitation and by underflow of dike-impounded water from the upgradient Koolau rift zone. Coastal sediments overlie and confine the Koolau aquifer along the coast and extend inland in the valleys. In the Waialae area, the combination of rift zone and dike boundaries and thick caprock causes
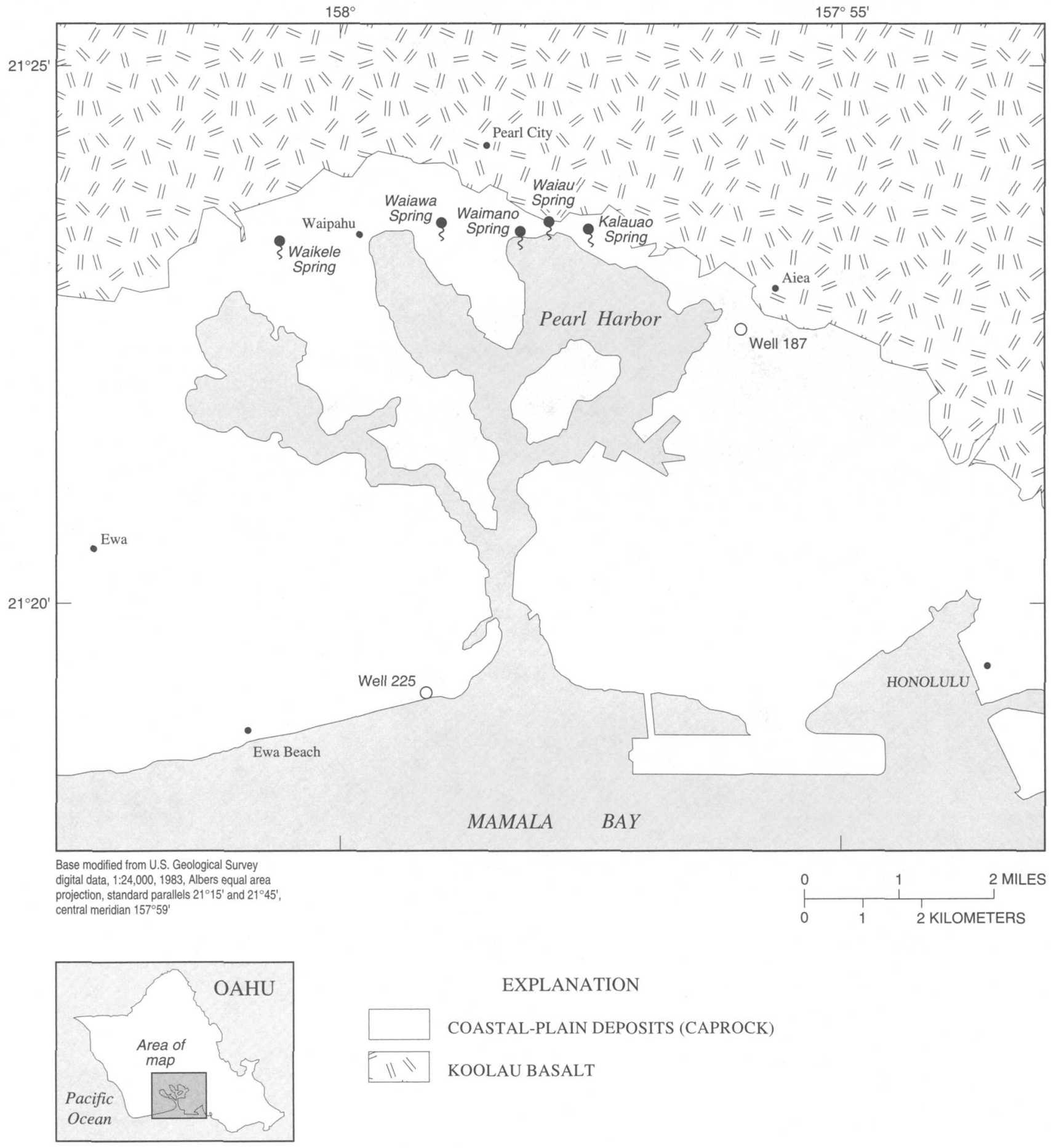

EXPLANATION

COASTAL-PLAIN DEPOSITS (CAPROCK)

KOOLAU BASALT

FIGURE 12.-Location of the Pearl Harbor springs, island of Oahu. 
moderate impoundment of freshwater, with inland freshwater heads ranging from 10 to $15 \mathrm{ft}$ above sea level and having a pronounced shoreward gradient (Eyre and others, 1986).

\section{SALTWATER FLOW SYSTEM}

Few measurements of saltwater head have been made on Oahu and little is known about the saltwater flow system underlying the freshwater flow systems. Waterlevel records for well 225, which is open to saltwater at a depth of $1,100 \mathrm{ft}$, and well 187 , which is open only to freshwater, are shown in figure 13. The casing of well 225 apparently has one or more breaks that have allowed brackish water from sediments higher in the stratigraphic section to enter the well and dilute the saltwater; this lowers the fluid density from that of seawater and raises the head correspondingly. Alternately, the well bottom may be open to the lower part of the transition zone in the Koolau aquifer and thereby not tap 100 percent saltwater. The water-level record for the saltwater well has not been corrected for this dilution, which may vary over time; correction for dilution would shift the record downward slightly. However, the well is open in or near the deep saltwater zone of the volcanic-rock aquifer, and it is presumed that the water-level fluctuations reflect fluctuations in saltwater head.

Water-level fluctuations in the freshwater well, 187, reflect transient pumping and recharge stresses and are similar to fluctuations observed elsewhere in southern Oahu. Water-level fluctuations in the saltwater well are similar to those in the freshwater well, except for a slightly smaller range of fluctuation (fig. 13). The similarity in water-level fluctuations indicates that the volumetric addition and withdrawal of freshwater pressurizes and depressurizes the confined part of the coupled freshwater-saltwater flow system, causing fluctuations in freshwater and saltwater head of almost equal magnitude and with no lag. In the freshwater zone, freshwater head fluctuates about an average value that is positive with respect to sea level. In the saltwater zone, head fluctuates about some average saltwater head that is not zero, but in theory must be slightly negative in order to maintain dispersion-driven saltwater circulation (Cooper, 1959).

The saltwater flow system responded to the withdrawals from Oahu aquifers that began about 1880 . As a result of this development, freshwater heads decreased rapidly and basal freshwater lenses shrank, particularly in southern Oahu. Records of salinity for these early wells (Stearns and Vaksvik, 1938) show a clear pattern of progressive saltwater encroachment, both lateral and vertical, in response to freshwater storage depletion. Visher and Mink (1964) presented a map of chloride concentration for the Pearl Harbor area, showing progressive inland movement of the $200-$ and $1,000-\mathrm{mg} / \mathrm{L}$ (milligram per liter) lines of concentration between 1910 and 1950 . The $1,000-\mathrm{mg} / \mathrm{L}$ line shifted about $1.5 \mathrm{mi}$ inland over this time.

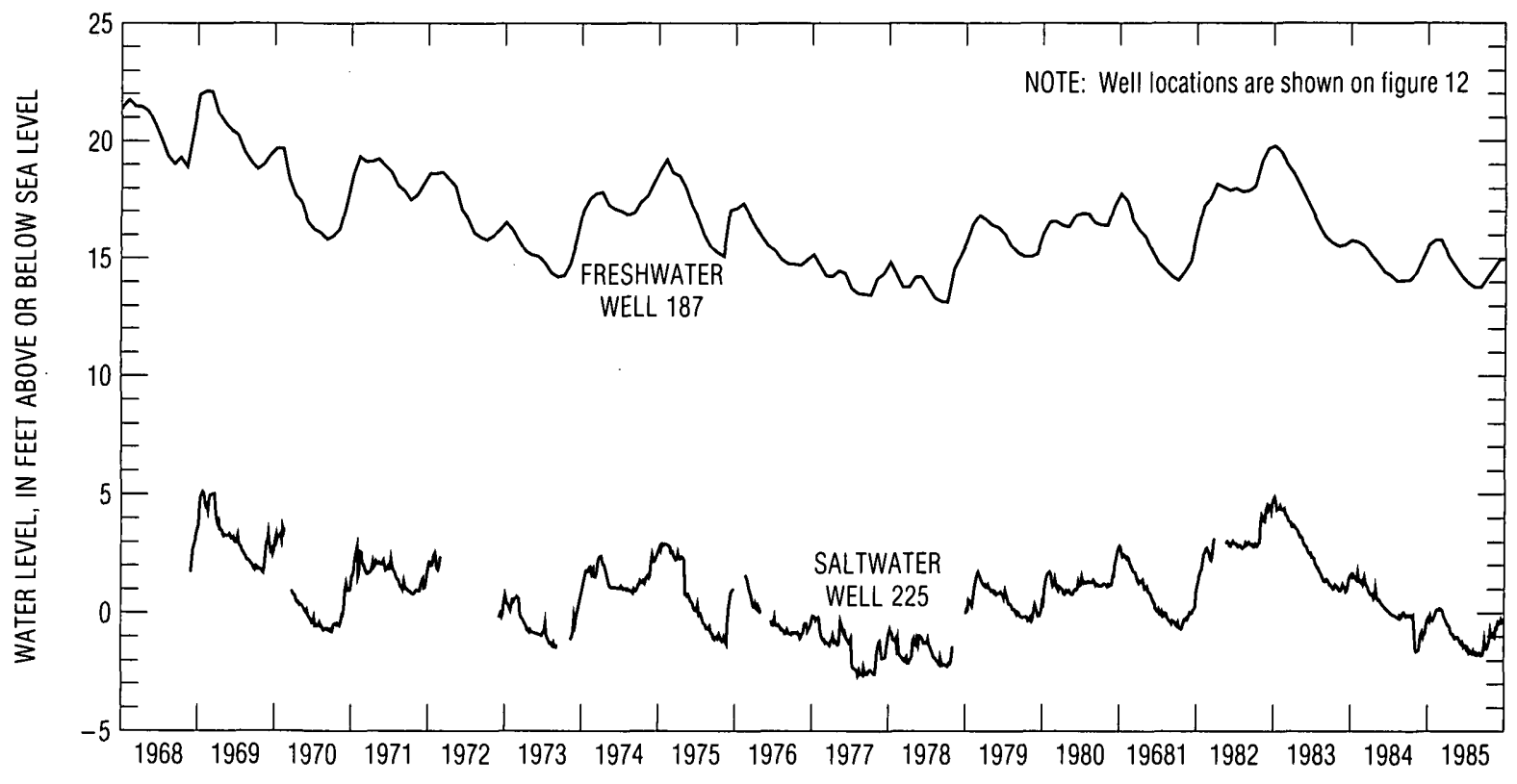

FigurE 13.-Water levels in well 187 open to freshwater and well 225 open to saltwater in the Pearl Harbor area, island of Oahu. 


\section{GROUND-WATER DISCHARGE AND THE DEVELOPMENT OF GROUND WATER IN THE VOLCANIC-ROCK AQUIFERS}

Before ground-water development began, ground water discharged naturally by evapotranspiration in areas of shallow ground water, by spring discharge, by discharge directly to the sea, and by diffuse leakage through the caprock where it is present. Ground water still discharges by these methods, but the natural discharge in some areas, notably the Pearl Harbor groundwater area, is much diminished as a result of groundwater pumpage. The major spring discharge is from a number of large springs around the northern perimeter of Pearl Harbor (fig. 12); there also are several large springs in the Kahuku ground-water area of windward Oahu.

Ground-water use averaged about $394 \mathrm{Mgal} / \mathrm{d}$ from all sources in 1980 (Nakahara, 1980). Of this, about 81 percent, or $318 \mathrm{Mgal} / \mathrm{d}$, was pumped from the volcanicrock aquifers of the island, with $238 \mathrm{Mgal} / \mathrm{d}$ being pumped from the southern Oahu area alone. About 19 percent, or $76 \mathrm{Mgal} / \mathrm{d}$, of the total from all sources was derived from water-development tunnels, flowing wells, and pumpage from aquifers in the caprock.

\section{DISCHARGE BY SPRINGS}

Ground water is discharged naturally by subaerial and submarine springs in southern, windward, and northern Oahu. Stearns and Vaksvik (1935, p. 371) mentioned a group of springs along the southwest bank of Anahulu Stream just north of Haleiwa (fig. 2) that was estimated to discharge about $1 \mathrm{Mgal} / \mathrm{d}$ in 1933 . About a mile northeast, near Kawailoa (fig. 2) was another large spring estimated to have discharged as much as $5 \mathrm{Mgal} / \mathrm{d}$ (Stearns and Vaksvik, 1935, p.371). Stearns and Vaksvik (1935, p. 371) also mentioned a spring near Kawailoa Beach (fig. 2) and speculated that there might be significant spring discharge from the Koolau Basalt where it is exposed near the coast at Waimea Bay, Kawela Bay, Kahuku, Laie, and Hauula (fig. 2). They estimated total discharge from all these springs to be about $12 \mathrm{Mgal} / \mathrm{d}$. Later investigators (Takasaki and others, 1969; Takasaki and Valenciano, 1969; Rosenau and others, 1971; and Dale, 1978) made no mention of any of these springs. Except for Punamano Spring near Kahuku Point (fig. 2), none of these springs are shown on recent (1983) maps of the U.S. Geological Survey.

Most springs on Oahu are located around the northern perimeter of Pearl Harbor from near Aiea on the east to near Honouliuli on the west (figs. 2, 12). The earliest description of these springs was by Schuyler and Allardt (1889). The Pearl Harbor springs consist of five large springs or groups of springs named Kalauao, Waiau, Waimano, Waiawa, and Waikele, from east to west (fig. 12). Stearns and Vaksvik (1935, p. 367) reported measured discharge from all but Waikele Spring for 1932 and 1933. By estimating the discharge from Waikele Spring at about $8 \mathrm{Mgal} / \mathrm{d}$, total discharge from the Pearl Harbor springs was estimated to be about 82 $\mathrm{Mgal} / \mathrm{d}$ in 1932 and about $79 \mathrm{Mgal} / \mathrm{d}$ in 1933 . Visher and Mink (1964) estimated that the average discharge of the springs for $1953-57$ was about $87 \mathrm{Mgal} / \mathrm{d}$. Soroos and Ewart (1979) subsequently developed a linear relation between spring discharge and the water level in well 187 (fig. 12) near Aiea. This well was not drilled until 1935. Correlating the water-level record from well 2102-03 near Honouliuli (fig. 2) drilled in 1910 with water levels in well 187 enabled Soroos and Ewart to estimate total spring discharge from 1911. Using information given by Visher and Mink (1964), a similar relation between water level and spring discharge was determined for individual springs or spring groups (fig. 14, table 4), also beginning in 1911. Estimates of total spring discharge made by the two methods generally agree within 2 percent.

Predevelopment spring discharge was estimated to be about 176 to $183 \mathrm{Mgal} / \mathrm{d}$ depending on the water level used (32 ft or $33 \mathrm{ft}$ ). Discharge in 1932 and 1933 was estimated to be 108 and $103 \mathrm{Mgal} / \mathrm{d}$, respectively, suggesting that the estimate made by Stearns and Vaksvik (1935) for Waikele Spring was too low. The present estimate for Waikele spring is about $35 \mathrm{Mgal} / \mathrm{d}$ for 1932 and about $33 \mathrm{Mgal} / \mathrm{d}$ for 1933 . The estimated average discharge for $1953-57$ is about $93 \mathrm{Mgal} / \mathrm{d}$ compared to the $87 \mathrm{Mgal} / \mathrm{d}$ estimated by Visher and Mink (1964). The minimum discharge of the Pearl Harbor springs is estimated to be about 46 to $48 \mathrm{Mgal} / \mathrm{d}$ during 1977 and 1978. Discharge is estimated to have recovered to about $80 \mathrm{Mgal} / \mathrm{d}$ by 1983 .

\section{HISTORICAL DEVELOPMENT, 1879-1980}

The development of the ground-water resources on Oahu began when the first well was drilled near Honouliuli in the summer of 1879 (Stearns and Vaksvik, 1935 , p. 240). By early 1882,16 wells had been drilled in Honolulu; 13 of these were flowing wells and 3 were nonflowing. In addition to the flowing well near Honouliuli, another flowing well had been drilled in the Kahuku area. By 1890, 86 wells had been drilled on the island (table 5). From about 1891 to about 1910, development increased rapidly with the drilling of a large 
number of wells for irrigation of sugarcane in southern and northern Oahu and in the Kahuku area of windward Oahu (fig. 15A, tables 5-7); 160 of these wells are still in use, and as many as 74 other wells drilled for irrigation during this time have been abandoned and destroyed.

Pumping of significant quantities of ground water is thought to have begun in southern Oahu about 1890 when the Ewa Plantation was formed to grow sugarcane. In 1897, the Oahu Sugar Co. began drilling, and, in 1900, the Honolulu Plantation began development (Mink, 1980, p. 25). These three companies, irrigating from 25,000 to 30,000 acres of sugarcane, were the principal producers of ground water in southern Oahu until World War II (Mink, 1980, p. 25). By far, the largest number of wells for irrigation were drilled in the southern and northern Oahu ground-water flow systems (fig. $15 B)$.

Five wells had been drilled by 1884 to augment the water-supply system in Honolulu (Stearns and Vaksvik, 1935 , p. 248). Pumping of ground water for public sup- ply began about 1900 when batteries of deep wells were equipped with steam-driven suction pumps (Visher and Mink, 1964, 42). By 1910, with the population of Honolulu at 52,183 (table 8), at least 27 wells had been drilled for public supply; 12 additional wells, since destroyed, also might have been drilled for this purpose during this time. By 1930, at least 673 wells had been drilled on Oahu for all uses; of these, 62 are still in use for public supply. The population of Oahu grew from 202,923 in 1930 to 258,256 in 1940 , while that of Honolulu increased from 137,582 to 179,326 (table 8 ). The major population growth occurred following World War II and following statehood in 1959; the population of Oahu had reached 762,565 by 1980 and that of Honolulu was 365,048 . The demand for ground water for public water supply correspondingly increased. Ninety-three wells were drilled for public supply from 1941 to 1970 , with another 58 drilled in the decade following 1970 (fig. 164); of these, 96 were drilled in southern Oahu, 63 from 1941 to 1970 and 33 from 1971 to 1980 (table 6 , fig. 16A). The cumulative number of wells drilled for

TABLE 4.-Estimated annual mean daily spring discharge, Pearl Harbor springs area, island of Oahu, by decade, 1911-80

[All values in million gallons per day]

\begin{tabular}{lccccr}
\hline Decade & Kalauao & Waiau-Waimano & Waiawa & Waikele & Total \\
\hline $1911-20$ & 25.0 & 39.6 & 18.0 & 45.1 & 127.7 \\
$1921-30$ & 19.9 & 33.7 & 14.4 & 31.0 & 99.0 \\
$1931-40$ & 20.0 & 33.8 & 14.5 & 31.1 & 99.4 \\
$1941-50$ & 16.5 & 29.8 & 12.1 & 23.0 & 81.4 \\
$1951-60$ & 18.5 & 32.1 & 13.5 & 27.5 & 91.6 \\
$1961-70$ & 16.4 & 29.7 & 12.0 & 22.7 & 80.8 \\
$1971-80$ & 12.4 & 25.0 & 9.2 & 14.8 & 61.4 \\
\hline
\end{tabular}

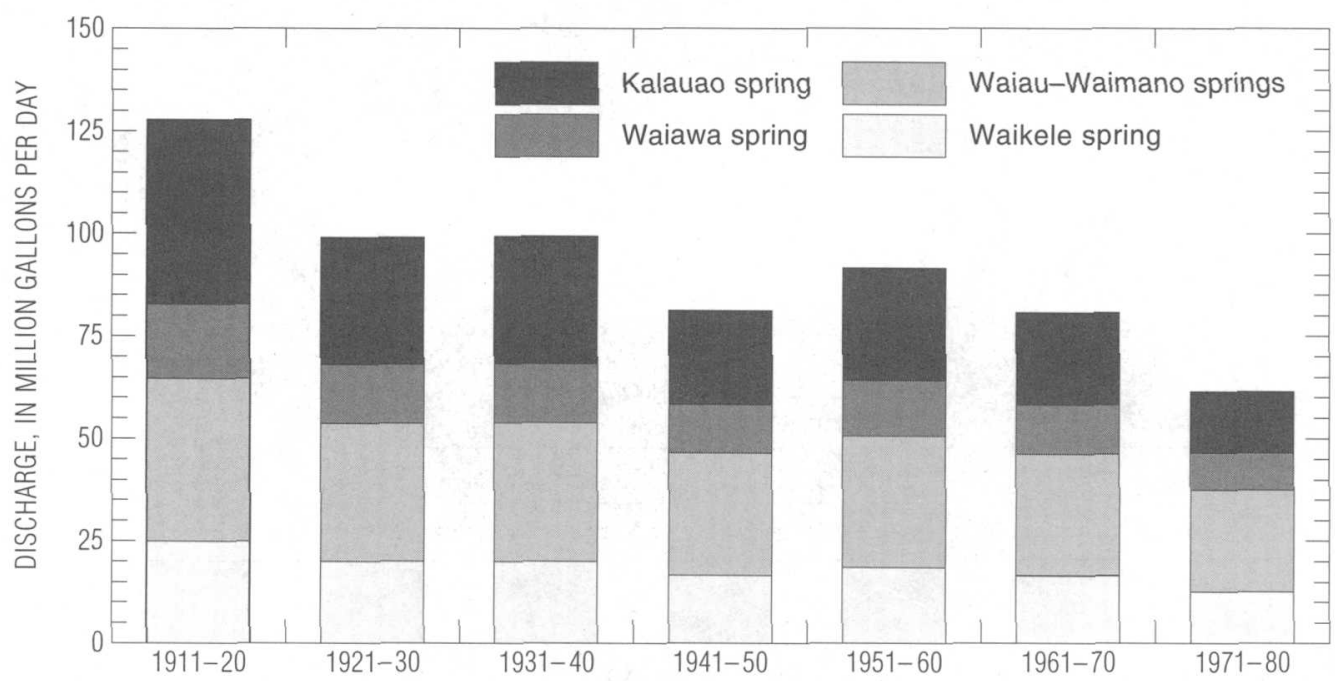

Figure 14.-Estimated mean daily discharge of the Pearl Harbor springs, island of Oahu, by decade, 1911-80. 
TABLE 5.-Number of wells, tunnels, and shafts drilled or constructed for ground-water development each decade, 1881-1985, in each ground-water flow system, island of Oahu

[From data in Miyamoto and others, 1986]

\begin{tabular}{ccccccccc}
\hline $\begin{array}{c}\text { Ground-water } \\
\text { flow system }\end{array}$ & $1881-90$ & $1891-1900$ & $1901-10$ & $1911-20$ & $1921-30$ & $1931-40$ & $1941-50$ \\
\hline Southern & 68 & 169 & 122 & 27 & 66 & 73 & 96 \\
Southeastern & 2 & 0 & 0 & 1 & 0 & 8 & 12 \\
Eastern (windward) & 12 & 12 & 5 & 4 & 33 & 51 & 38 \\
Northern & 2 & 69 & 6 & 21 & 25 & 22 & 14 \\
Western (Waianae) & 2 & 0 & 0 & 27 & 0 & 41 & 48 \\
Total & 86 & 250 & 133 & 80 & 124 & 195 & 208 \\
\hline Ground-water & $1951-60$ & $1961-70$ & $1971-80$ & $1981-85$ & No date & Total & \\
flow system & 142 & 81 & 59 & 9 & 9 & 921 \\
\hline Southern & 9 & & 1 & 4 & 0 & & \\
Southeastern & 26 & 24 & 15 & 6 & 3 & 229 & \\
Eastern (windward) & 29 & 35 & 11 & 1 & 0 & 235 & \\
Northern & 51 & 33 & 6 & 1 & 0 & 209 & \\
Western (Waianae) & 257 & 177 & 92 & 21 & 12 & 1,635 & \\
Total & & & & & & & \\
\hline
\end{tabular}

TABLE 6.-Number of wells, tunnels, and shafts drilled or constructed for ground-water development each decade that are still in existence in 1985, by use category, island of Oahu

[From data in Miyamoto and others, 1986. -, no data]

\begin{tabular}{lccccccc}
\hline \multicolumn{1}{c}{ Use } & $1881-90$ & $1891-1900$ & $1901-10$ & $1911-20$ & $1921-30$ & $1931-40$ & $1931-40$ \\
\hline Public supply & 5 & 21 & 1 & 13 & 22 & 16 & 18 \\
Irrigation & 7 & 104 & 56 & 16 & 49 & 52 & 13 \\
Other & 2 & 7 & 8 & 4 & 10 & 26 & 31 \\
Total & 14 & 132 & 65 & 33 & 81 & 94 & 62 \\
\hline \multicolumn{1}{c}{ Use } & $1951-60$ & $1961-70$ & $1971-80$ & $1981-85$ & No date & Total \\
\hline Public supply & 30 & 45 & 58 & 10 & 8 & & 247 \\
Irrigation & 62 & 14 & 6 & - & 4 & 383 \\
Other & 58 & 36 & 13 & 2 & 8 & 205 \\
Total & 150 & 95 & 77 & 12 & 20 & & 835 \\
\hline
\end{tabular}

TABLE 7.-Number of wells, tunnels, and shafts drilled or constructed for ground-water development in each ground-waterflow system, 1881-1985, by use category,

island of Oahu

[From data in Miyamoto and others, 1986]

\begin{tabular}{lcccccr}
\hline & \multicolumn{5}{c}{ Ground-water flow system } & \\
\cline { 2 - 6 } \multicolumn{1}{c}{ Use } & Southern & Southeastern & Northern & Eastern & Western & Total \\
\hline Public supply & 150 & 7 & 33 & 47 & 10 & 247 \\
Irrigation & 170 & 2 & 102 & 59 & 50 & 383 \\
Other & 139 & 8 & 8 & 28 & 22 & 205 \\
Unused & 158 & 5 & 39 & 63 & 90 & 355 \\
Abandoned ${ }^{1}$ & 304 & 19 & 53 & 32 & 37 & 445 \\
Total & 921 & 41 & 235 & 229 & 209 & 1,635 \\
\hline
\end{tabular}

${ }^{1}$ Most abandoned wells have been destroyed. 
public water supply largely reflects the increase in population of both Honolulu and Oahu (fig. 17).

By 1985, at least 1,635 wells, tunnels and shafts, had been drilled on Oahu for the development of groundwater resources (tables 5-7, fig. 18). Of these, 445 have been abandoned and destroyed and another 355 were unused in 1985 (table 7, fig. 18). By far, the largest number of wells have been drilled in southern Oahu, mostly for public supply and irrigation (table 7, fig. 19). In 1985, there were 1,190 existing wells, tunnels, and shafts for ground-water development on Oahu (fig. 20) The general distribution is shown in figure 21 .
TABLE 8.-Population of Honolulu and island of Oahu [Data from Hawaii Department of Planning and Research, 1962; Hawaii Department of Planning and Economic Development, 1977, 1983; U.S. Department of Commerce, 1901, 1913, 1921, 1953, 1992]

\begin{tabular}{ccc}
\hline Decade & Honolulu & Oahu \\
\hline 1890 & 22,907 & 31,194 \\
1900 & 39,306 & 58,504 \\
1910 & 52,183 & 82,028 \\
1920 & 83,327 & 123,527 \\
1930 & 137,582 & 202,923 \\
1940 & 179,326 & 258,256 \\
1950 & 248,034 & 353,020 \\
1960 & 294,179 & 500,409 \\
1970 & 325,000 & 630,528 \\
1980 & 365,048 & 762,565 \\
1990 & 365,272 & 836,231 \\
\hline
\end{tabular}

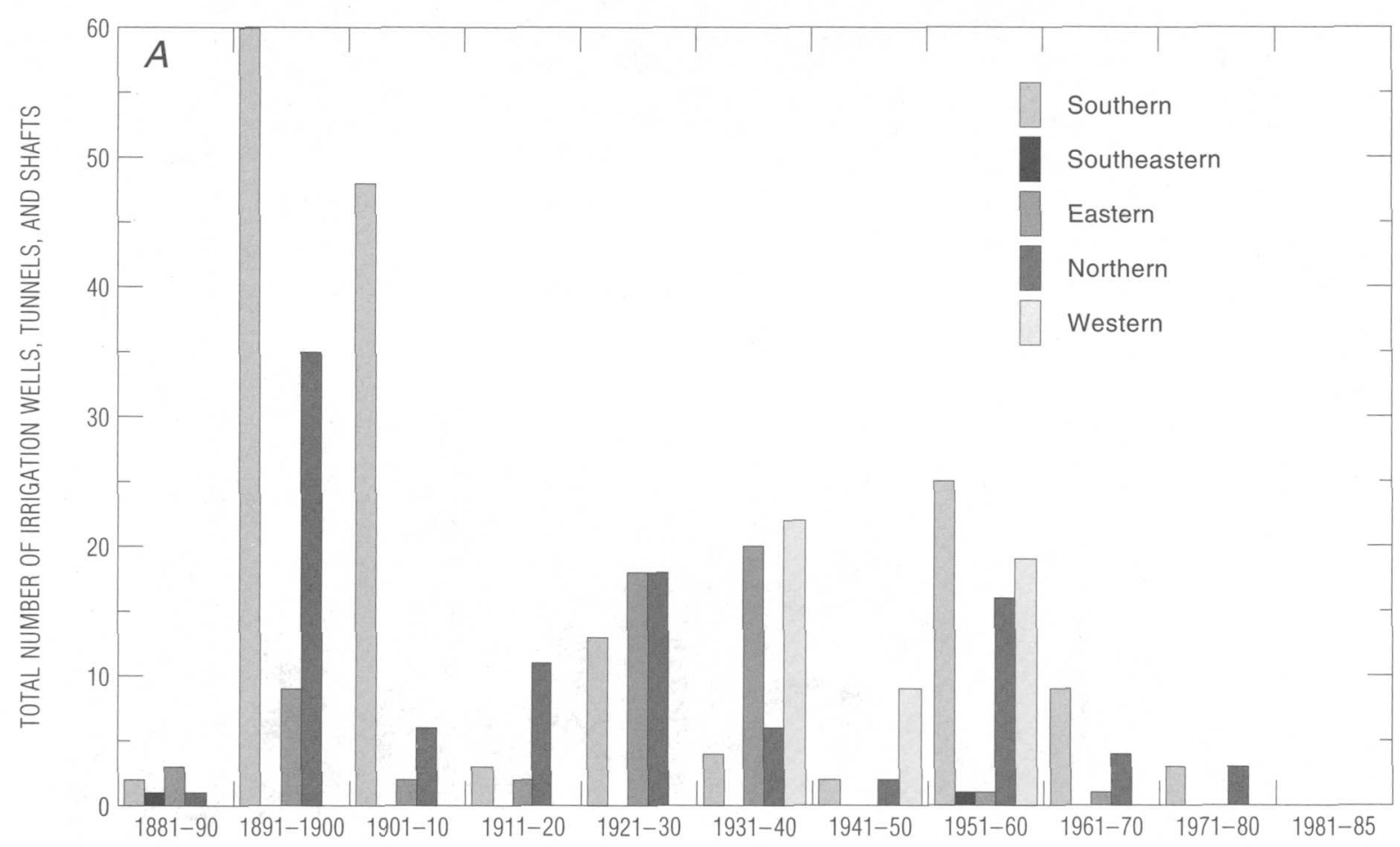

FIGURE 15.-Number of wells, tunnels, and shafts drilled or constructed for irrigationwater supply, island of Oahu.

$A$, Number in each ground-water flow system, by decade, 1881-1985;

$B$, Percentage of wells in each ground-water flow system, 1985.

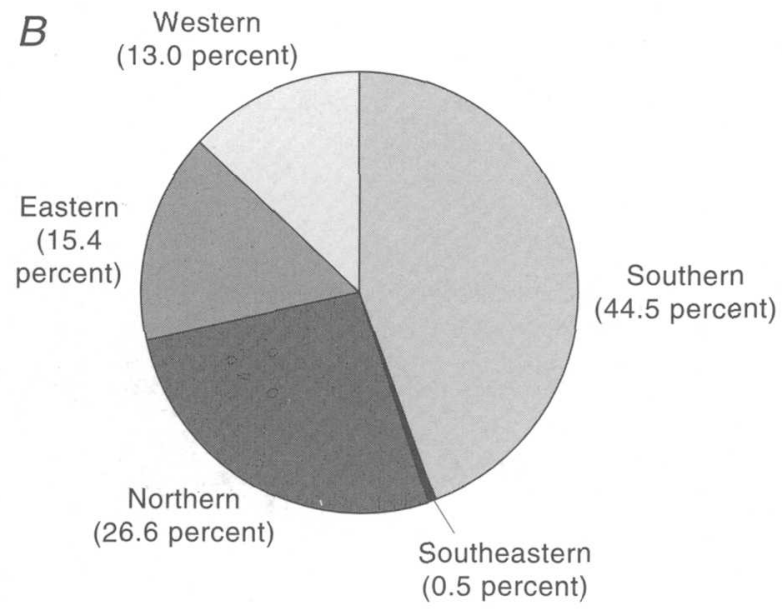


Before 1900, few records of ground-water pumpage were kept, and, from 1901 to 1910 , the available records are incomplete. The following discussion considers only the ground water pumped from the volcanic-rock aquifers. Ground-water pumpage from 1901 to 1910 averaged at least $88.9 \mathrm{Mgal} / \mathrm{d}$ (tables 9, 10, fig. 22). Pumpage increased to $159.8 \mathrm{Mgal} / \mathrm{d}$ during the following decade and, by the decade ending in 1930 , averaged 216.6 $\mathrm{Mgal} / \mathrm{d}$. The greatest pumpage was from the southern Oahu area, which accounted for 89 percent of the average pumpage from 1911 to 1920 and 84 percent during the next decade (tables 9, 10, fig. 22). Much of the mean daily pumpage of $221.7 \mathrm{Mgal} / \mathrm{d}$ in 1930 was for irrigation of sugarcane, which by now covered 43,277 acres [(table 11, fig. 23, appendix (at back of report)]. The use of ground water for irrigation of sugarcane has declined as the acres planted in sugarcane have declined and as more efficient methods of irrigation, such as drip irrigation, have been adopted, the latter beginning in the 1970's and accounting for nearly 50 percent of irrigated sugarcane acreage by 1980 (Hawaiian Sugar Planters Association, written commun., 1993). Ground-water pumpage for all uses increased from an average of 320.3 $\mathrm{Mgal} / \mathrm{d}$ in 1941 to $413.2 \mathrm{Mgal} / \mathrm{d}$ in 1970. Pumpage from the southern Oahu area averaged $228.3 \mathrm{Mgal} / \mathrm{d}$ in 1941 and $290.1 \mathrm{Mgal} / \mathrm{d}$ in 1970. Pumpage of ground-water from the volcanic-rock aquifers for all uses decreased to $318.7 \mathrm{Mgal} / \mathrm{d}$ by 1980 , with $238.1 \mathrm{Mgal} / \mathrm{d}$ pumped from
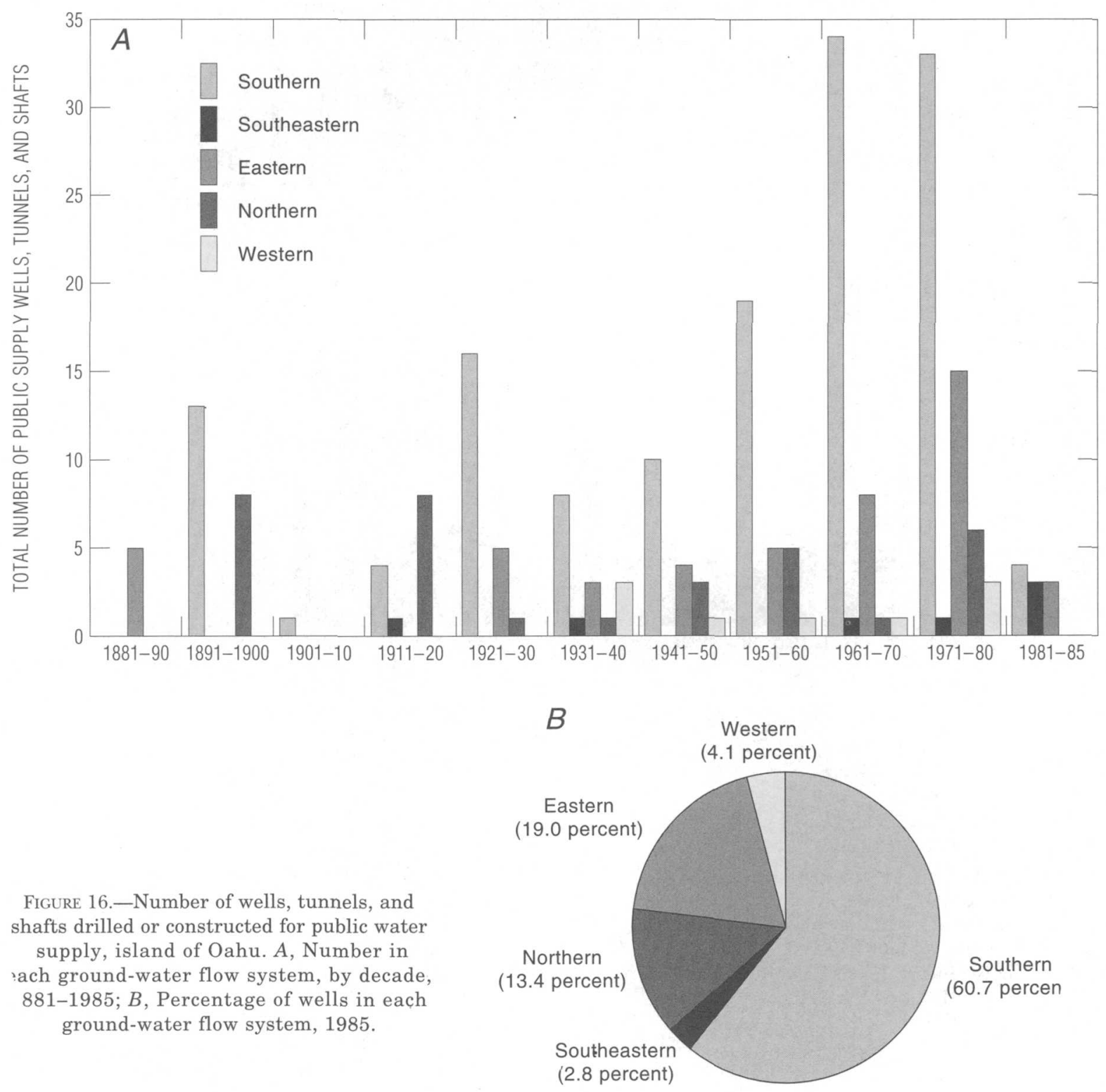
the southern Oahu area. Decade averages of groundwater pumpage increased from $309.5 \mathrm{Mgal} / \mathrm{d}$ in the 1940 's to $360.7 \mathrm{Mgal} / \mathrm{d}$ by the 1970 's (tables 9 , 10, figs. $22,24)$.

\section{WATER-DEVELOPMENT TUNNELS AND SHAFTS}

Two unique methods of ground-water development used in Hawaii are tunnels and shafts. Tunnels (fig. 25) are used largely in the development of high-level dikeimpounded ground water. The tunnel is driven into the dike-intruded basalt of the Koolau and Waianae rift zones. As dikes are penetrated, water impounded behind them is released into the tunnel. Originally, each compartment was allowed to drain, which resulted in large initial discharges that rapidly declined as the compartment was dewatered. Subsequently, bulkheads were installed at the dike location so that the discharge could be controlled and the dike compartments could be used more effectively as storage reservoirs.

The first reported tunnel on Oahu was driven into the Koolau Basalt in windward Oahu in about 1888. Significant development of tunnels did not begin until af- ter the Waiahole tunnel was completed in 1915. Jorgensen (1916) appears to have been the first to associate the piercing of dikes by tunnels with the development of ground water. Twenty-two tunnels were developed in windward Oahu by 1955 . There also are 11 tunnels in southern Oahu, several of which are constructed in basalt that is not intruded by dikes. One tunnel was developed in southeastern Oahu and 25 in the Waianae area. Of the 59 tunnels, 24 are used for public supply and 31 (22 of which are in the Waianae area) are for irrigation; the other 4 are for other uses. Ground water derived from drainage from tunnels is not included in the ground-water pumpage figures for volcanic rocks presented in the previous section and listed in the appendix.

Water-development shafts are designed to skim large quantities of water from the surface of the basal freshwater lens and are most common in southern and northern Oahu. An inclined shaft is excavated through the basalt to the water table, then a long gallery (fig. 26) is excavated and pumps are installed at the water table. Skimming water from a large area at the surface of the water table reduces the risk of drawing underlying sea-

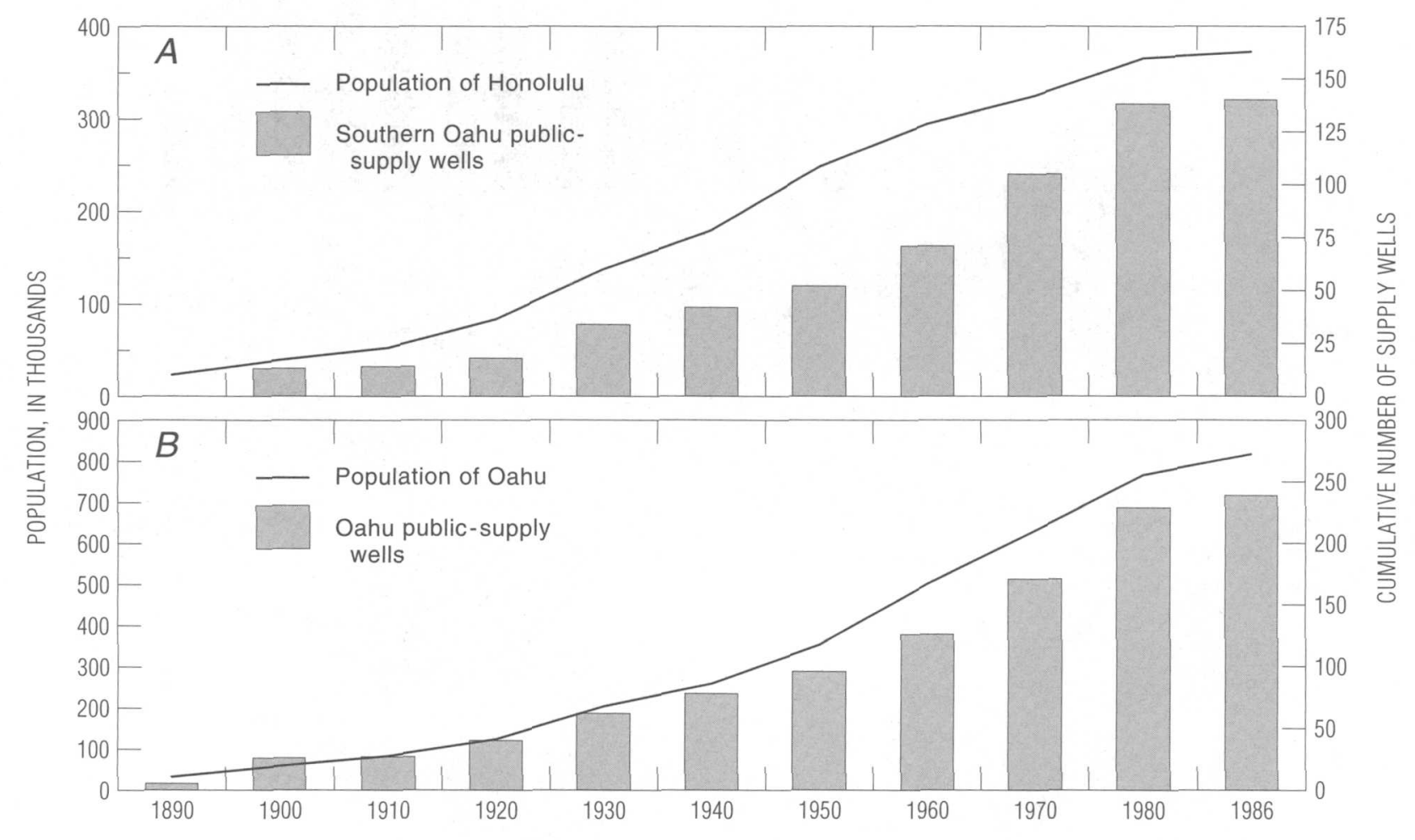

FiguRE 17.-Population of Honolulu and island of Oahu and the number of wells, tunnels, and shafts drilled or constructed for public water supply, 1890-1986. A, Honolulu; B, Oahu. 
water into the shaft. During the 1970's, Waiawa shaft was pumped at an average rate of $15 \mathrm{Mgal} / \mathrm{d}$ (Eyre, 1983).

The first reported shafts were constructed in 1937 in southern and southeastern Oahu. By 1956, 17 shafts had been constructed, 11 in southern Oahu and 3 in northern Oahu. Eleven of the shafts are for public water supply, and 2 were developed for irrigation. The remaining four are for other uses or are not used. Ground water pumped from shafts is included in the pumpage figures for volcanic rocks presented in the previous section.

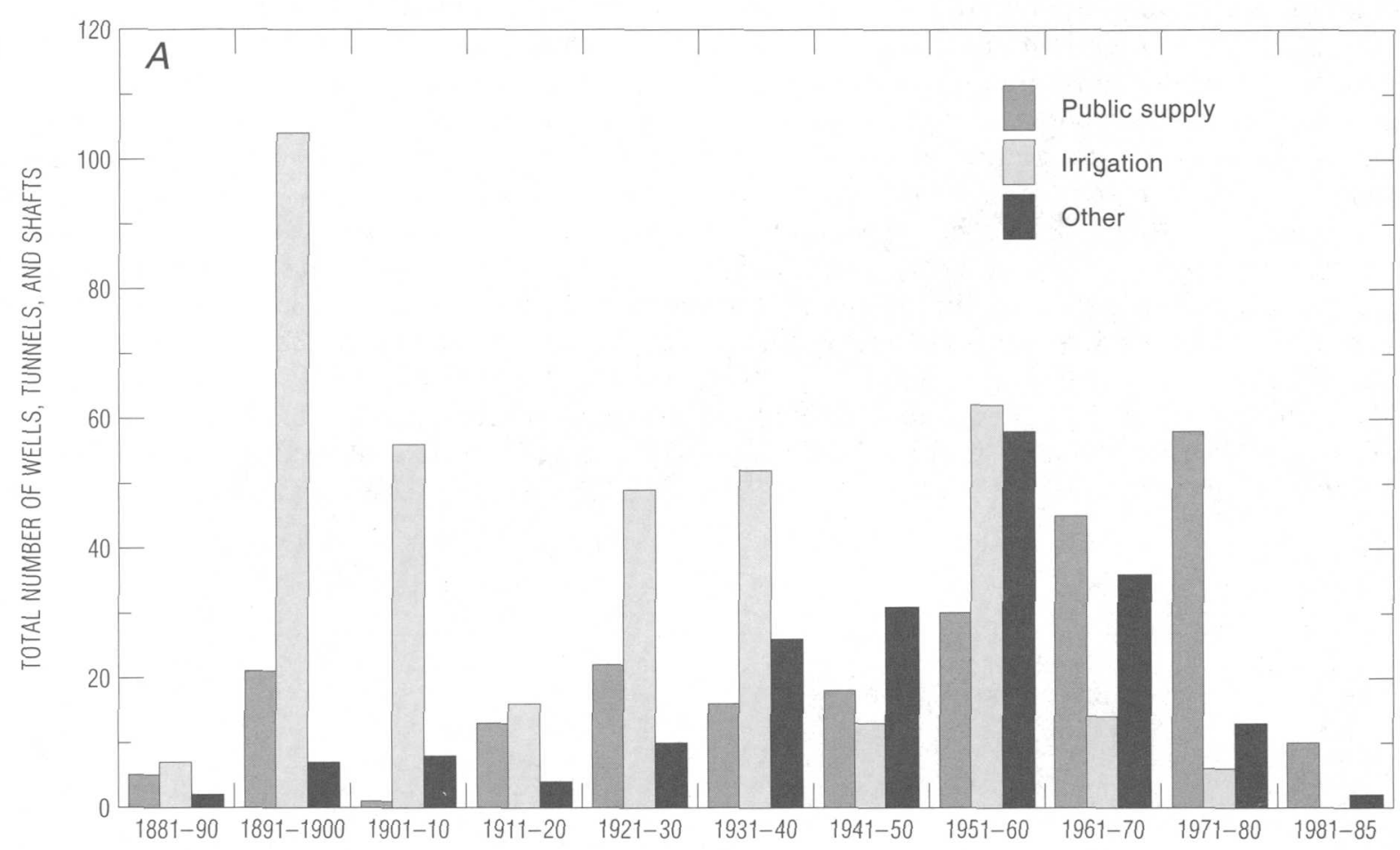

FigURE 18.-Number of wells, tunnels, and shafts drilled or constructed for ground-water development, island of Oahu, 1881-1985.

A, Number, by decade, 1881-1985;

$B$, Number and percentage by use.

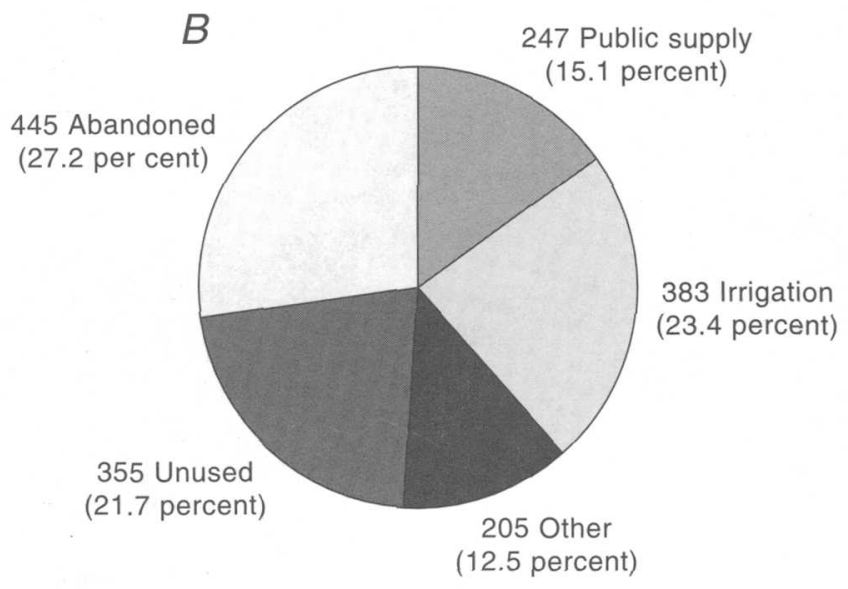



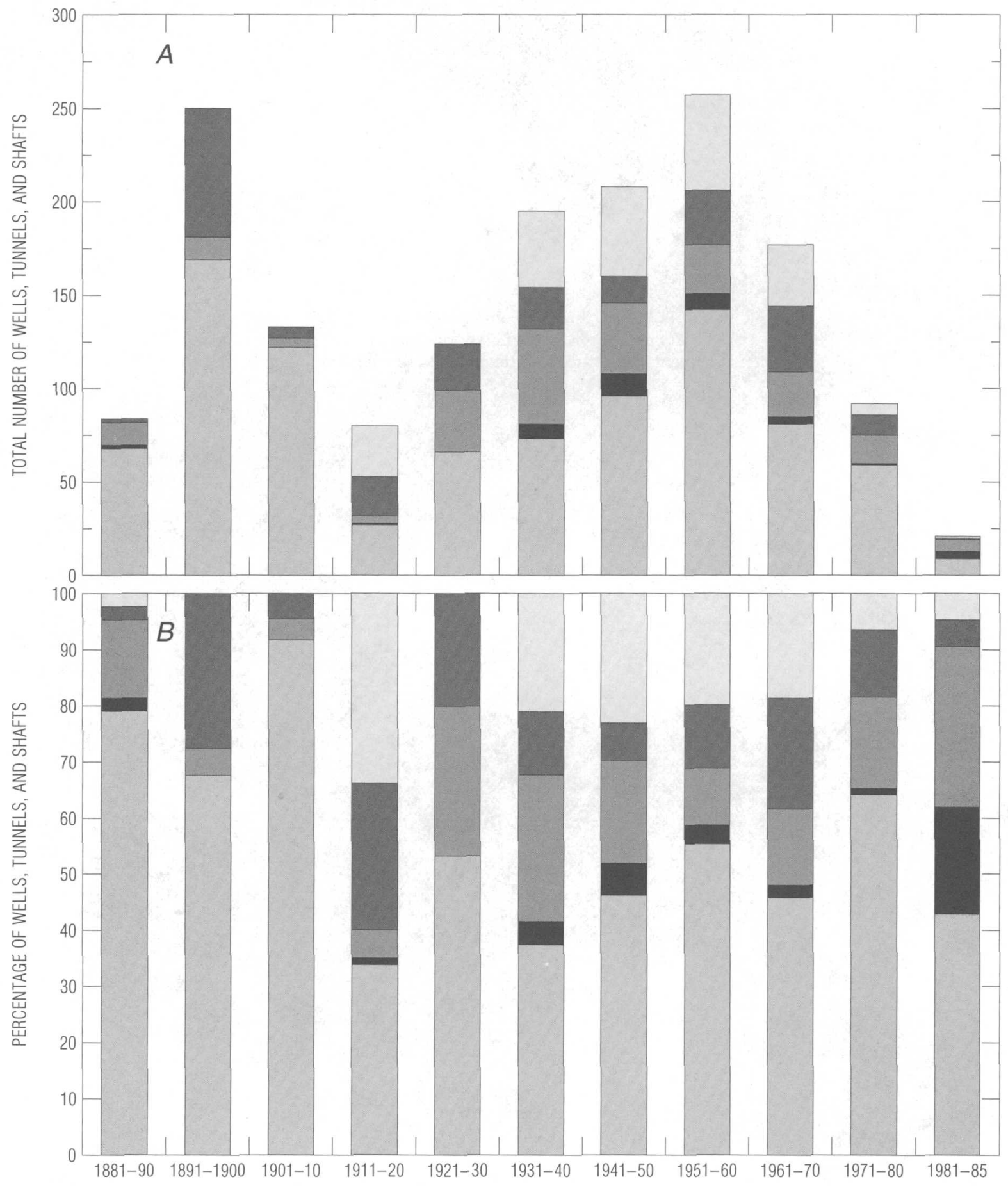

EXPLANATION flow system, island of Oahu, by decade, 1881-1985. A, Number; $B$, Percentage. 


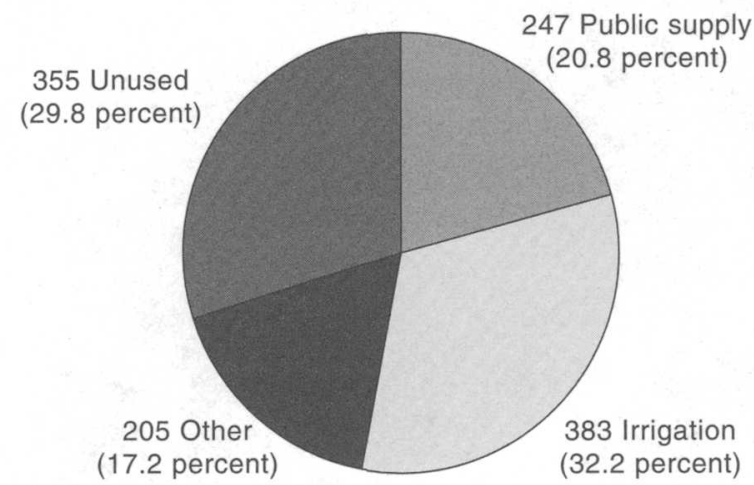

Figure 20.-Number and percentage of wells, tunnels, and shafts drilled or constructed for ground-water development and still in existence in 1985, island of Oahu.

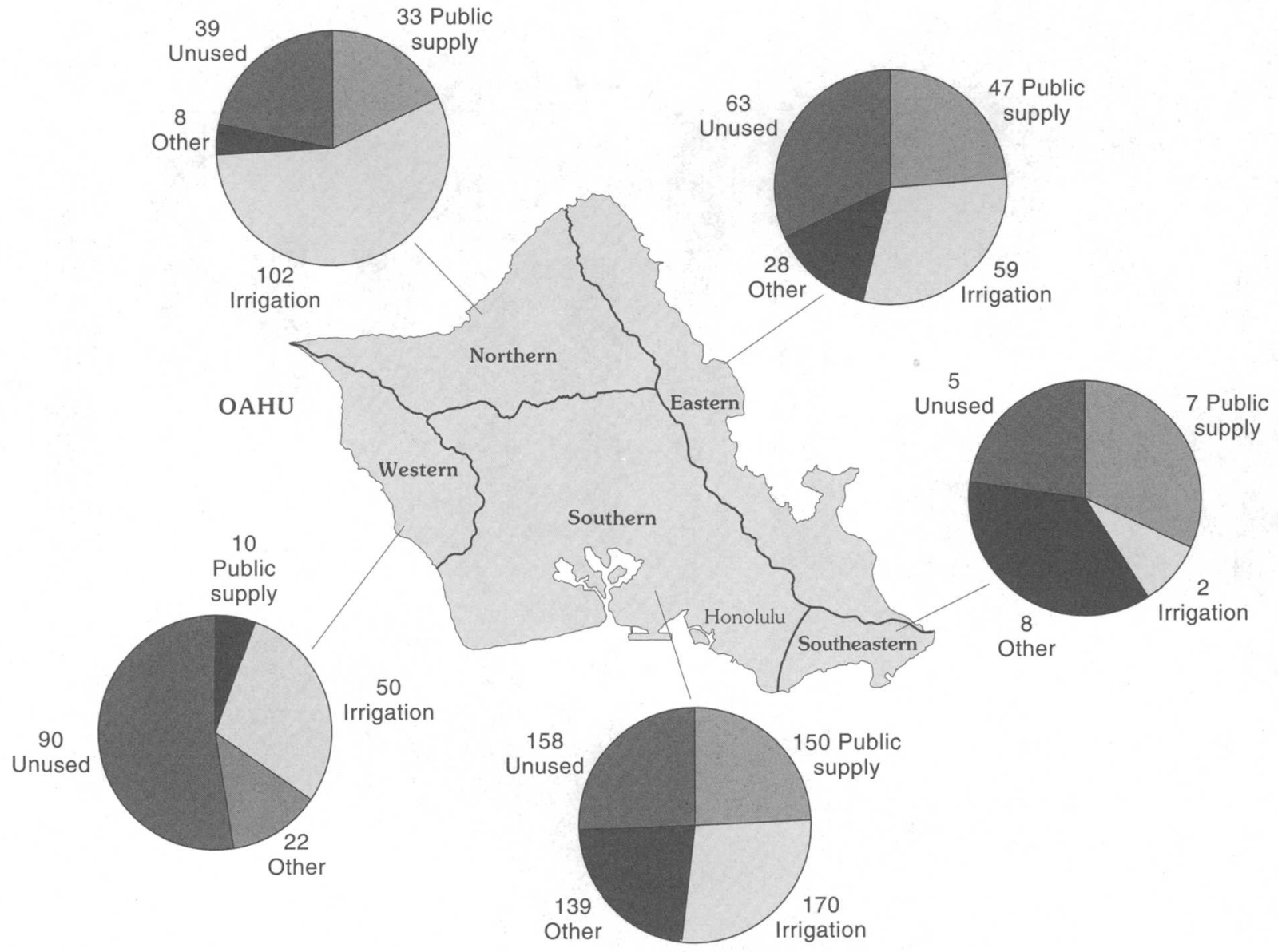

FIGURE 21.-Generalized distribution of wells, tunnels, and shafts drilled or constructed for ground-water development in each ground-water flow system and still in existence in 1985, island of Oahu. 
TABLE 9.-Summary of mean annual ground-water pumpage for each ground-water area, island of Oahu, by decade, 1901-80 [All values in million gallons per day]

\begin{tabular}{|c|c|c|c|c|c|c|c|c|}
\hline \multirow{3}{*}{ Decade } & \multicolumn{8}{|c|}{ Ground-water flow system } \\
\hline & \multirow{2}{*}{$\begin{array}{c}\begin{array}{c}\text { Western } \\
\text { (Waianae) }\end{array} \\
\text { Waianae Rift }\end{array}$} & \multicolumn{3}{|c|}{ Northern } & \multicolumn{2}{|c|}{ Southeastern } & \multicolumn{2}{|c|}{$\begin{array}{c}\text { Eastern } \\
\text { (windward) }\end{array}$} \\
\hline & & Mokuleia & Waialua & Kawailoa & Waialae & $\begin{array}{l}\text { Wailupe- } \\
\text { Hawaii Kai }\end{array}$ & Koolau Rift & Kahuku \\
\hline $1901-10$ & 0 & 0 & 0 & 0 & 0 & 0 & 0 & 7.9 \\
\hline $1911-20$ & 0 & 0.9 & 5.2 & 0 & 0 & 0 & 0 & 11.2 \\
\hline $1921-30$ & 0 & 2.2 & 21.4 & 1.8 & 0 & 0 & 0.2 & 10.0 \\
\hline $1931-40$ & 4.0 & 4.2 & 34.4 & 3.1 & 0.6 & 0 & 0.7 & 18.7 \\
\hline $1941-50$ & 3.2 & 4.1 & 37.8 & 4.2 & 1.1 & 0 & 2.8 & 31.1 \\
\hline $1951-60$ & 4.9 & 3.5 & 33.5 & 4.3 & 0.8 & 0 & 9.4 & 28.5 \\
\hline $1961-70$ & 4.4 & 3.9 & 36.4 & 7.0 & 0.7 & 0 & 11.4 & 27.7 \\
\hline $1971-80$ & 3.9 & 3.7 & 46.2 & 6.4 & 1.1 & 0 & 13.0 & 6.8 \\
\hline
\end{tabular}

\begin{tabular}{|c|c|c|c|c|c|c|c|}
\hline \multirow{3}{*}{ Decade } & \multicolumn{7}{|c|}{ Ground-water flow system-Continued } \\
\hline & \multicolumn{6}{|c|}{ Southern } & \multirow[b]{2}{*}{$\begin{array}{c}\text { Schofield } \\
\text { (southern flov } \\
\text { system) }\end{array}$} \\
\hline & Ewa & Pearl Harbor & Moanalua & Kalihi & Beretania & Kaimuki & \\
\hline $1901-10$ & 5.5 & 72.2 & 0 & 2.1 & 0 & 1.2 & 0 \\
\hline $1911-20$ & 17.9 & 120.7 & 0.1 & 2.3 & 0.1 & 1.5 & 0 \\
\hline $1921-30$ & 20.1 & 141.3 & 0.9 & 4.7 & 7.5 & 6.6 & 0 \\
\hline $1931-40$ & 19.7 & 139.2 & 5.6 & 8.2 & 8.8 & 5.6 & 0.8 \\
\hline $1941-50$ & 23.6 & 158.9 & 11.4 & 8.9 & 11.3 & 6.0 & 5.2 \\
\hline $1951-60$ & 24.2 & 149.5 & 11.5 & 9.5 & 9.7 & 4.8 & 4.7 \\
\hline $1961-70$ & 28.7 & 173.6 & 12.5 & 12.7 & 16.9 & 6.1 & 8.4 \\
\hline $1971-80$ & 31.1 & 190.3 & 13.8 & 9.9 & 14.6 & 5.4 & 14.7 \\
\hline
\end{tabular}

TABLE 10.-Summary of mean annual ground-water pumpage for the ground-water flow systems, island of Oahu, by decade, 1901-80

[All values in million gallons per day]

\begin{tabular}{ccccccr}
\hline & \multicolumn{5}{c}{ Ground-water flow system } \\
\cline { 2 - 6 } Decade & Southern & Southeastern & $\begin{array}{c}\text { Eastern } \\
\text { (windward) }\end{array}$ & Northern & $\begin{array}{c}\text { Western } \\
\text { (Waianae) }\end{array}$ & Total \\
\hline $1901-10$ & 81.1 & 0 & 7.8 & 0 & 0 & 88.9 \\
$1911-20$ & 142.5 & 0 & 11.2 & 6.1 & 0 & 159.8 \\
$1921-30$ & 181.1 & 0 & 10.2 & 25.3 & 0 & 216.6 \\
$1931-40$ & 187.9 & 0.6 & 19.4 & 41.8 & 4.0 & 253.6 \\
$1941-50$ & 225.3 & 1.1 & 33.8 & 46.1 & 3.2 & 309.5 \\
$1951-60$ & 214.0 & 0.8 & 38.0 & 41.3 & 4.9 & 298.9 \\
$1961-70$ & 258.9 & 0.7 & 39.0 & 47.3 & 4.4 & 350.3 \\
$1971-80$ & 279.7 & 1.1 & 19.7 & 56.2 & 3.9 & 360.7 \\
\hline
\end{tabular}


TABLE 11.-Acres planted in sugarcane, island of Oahu, 1930-85

[Hawaiian Sugar Planters' Association, written commun., 1993]

\begin{tabular}{cc}
\hline Year & Acres \\
\hline 1930 & 43,277 \\
1940 & 37,589 \\
1950 & 35,372 \\
1960 & 33,980 \\
1970 & 35,539 \\
1980 & 28,498 \\
1985 & 24,703 \\
\hline
\end{tabular}

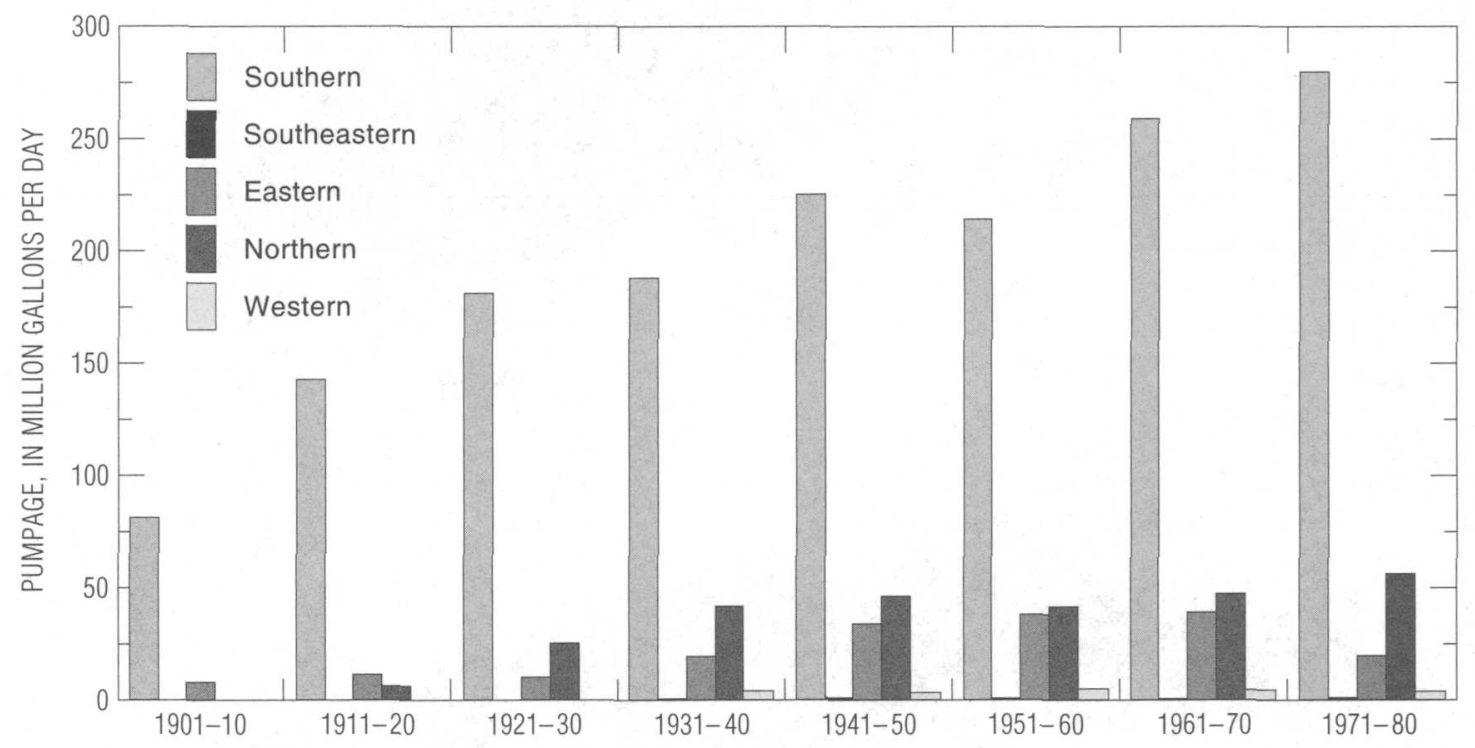

FIGURE 22.-Ground-water pumpage from the volcanic-rock aquifers of each ground-water flow system, island of Oahu, by decade, 1901-80.

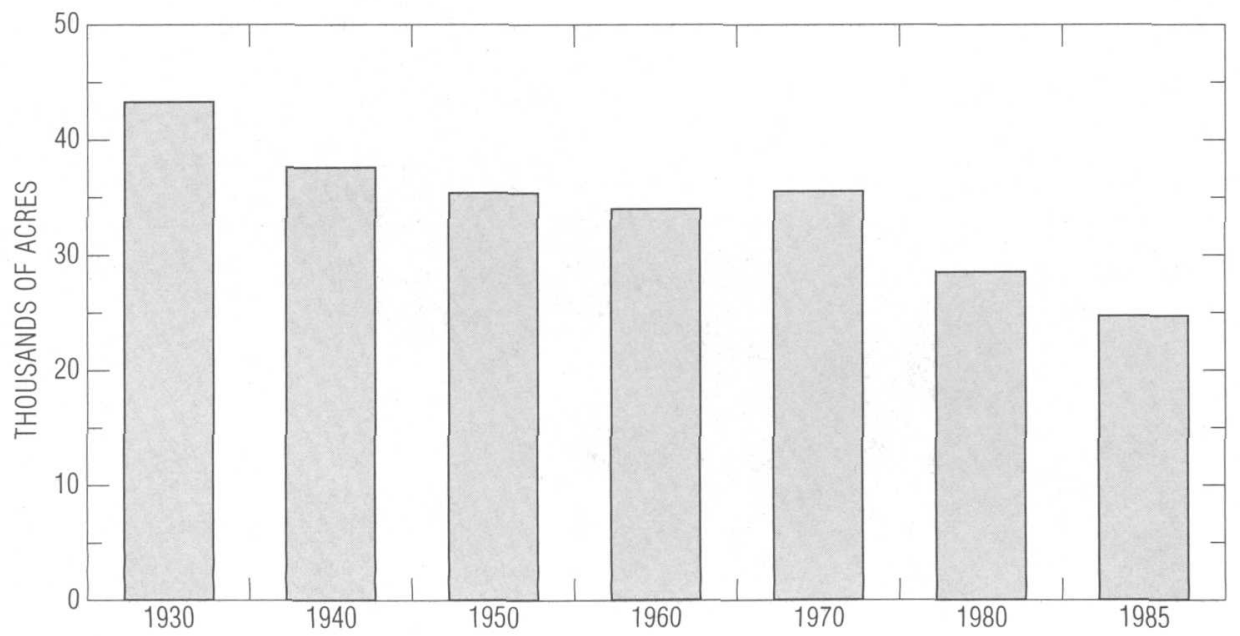

FIGURE 23.-Acres planted in sugarcane, island of Oahu, 1930-85 

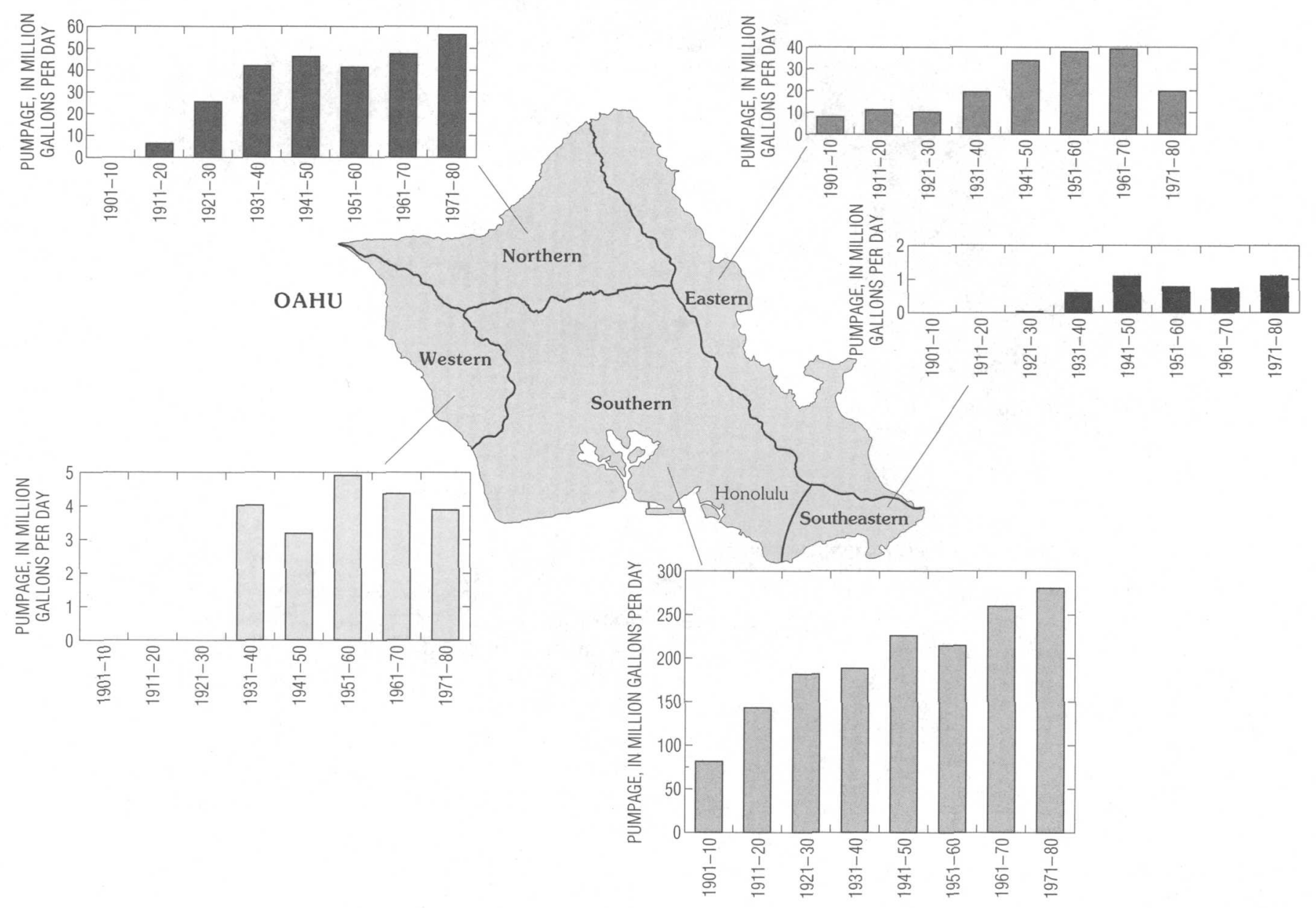

FIGURE 24.-Generalized distribution of mean annual ground-water pumpage from each ground-water flow system, island of Oahu, by decade, 1901-80.

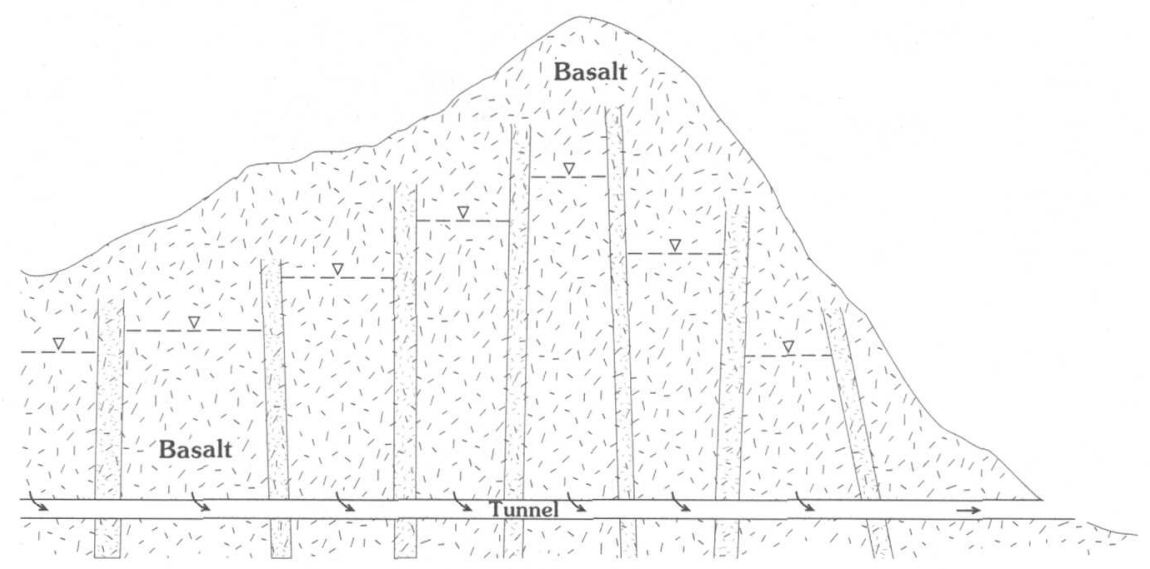

EXPLANATION

DIKE IN BASALT

- - WATER TABLE

$\leftarrow$ GENERALIZED DIRECTION OF GROUND-WATER FLOW

FIGURE 25.-Idealized diagram of a water-development tunnel. 


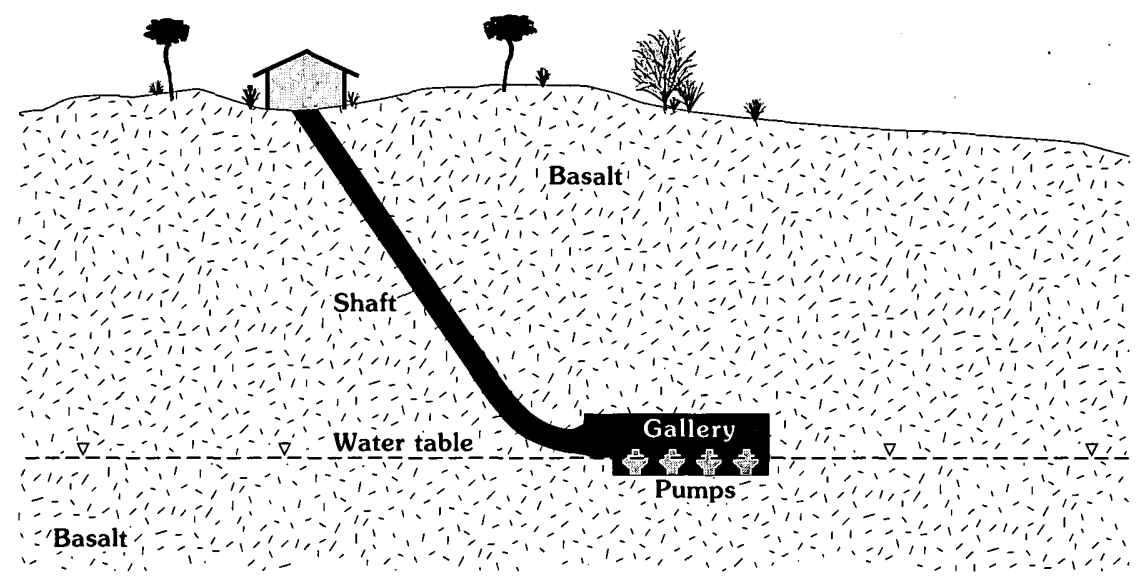

FIGURE 26.-Idealized diagram of a water-development shaft.

\section{GROUND-WATER LEVELS AND WATER-LEVEL TRENDS}

Few water level measurements are available before 1910 when continuous, or at least frequent, measurements began to be made.

\section{SOUTHERN OAHU}

Earliest Measurements in Beretania, Kalihi, and Moanalua Ground-Water Areas

The earliest water-level measurements are from the Beretania, Kalihi, and Moanalua ground-water areas of southern Oahu (figs. 9, 10, 27). A water level of $43.5 \mathrm{ft}$ above sea level was reported in the Beretania groundwater area in 1880 (Stearns and Vaksvik, 1935). The water level was at about $35 \mathrm{ft}$ by 1904 and declined to about $31 \mathrm{ft}$ by 1908 (fig. 27, table 12). Water levels continued to decline until the mid-1920's, after which there was a period of recovery to above $30 \mathrm{ft}$ in the early and late 1930 's. Water levels then generally declined to about $21 \mathrm{ft}$ by 1985 .

A water level of $41.7 \mathrm{ft}$ was measured in 1882 in the Kalihi ground-water area. The level had declined to about $28 \mathrm{ft}$ by 1923 (fig. 27). Levels recovered to about $31 \mathrm{ft}$ during the 1930 's, but by 1938 began a general decline that has continued into the 1980's. The level was at about $20 \mathrm{ft}$ in 1985 .

A water level in the Moanalua ground-water area was measured at $28.8 \mathrm{ft}$ in 1889 . Levels there had declined to about $28 \mathrm{ft}$ by 1910 (fig. 27), but recovered to about $30 \mathrm{ft}$ by 1916 . A general decline began in 1918 and water levels were at about $18 \mathrm{ft}$ by 1985 .

Earliest Measurements in Pearl Harbor, Ewa, and Kaimuki Ground-Water Areas

Hydrologically, the most important area of southern Oahu is the Pearl Harbor ground-water area (fig. 9B).
Early water levels in the lowland parts of the area around Pearl Harbor were estimated to be about $32 \mathrm{ft}$ above sea level (Stearns and Vaksvik, 1935). These levels increased inland at about $1.3 \mathrm{ft} / \mathrm{mi}$ (Stearns and Vaksvik, 1935, p. 259). By the time records were kept (1910), the water level near Honouliuli (fig. 27) was at about $21 \mathrm{ft}$. Heads here increased to nearly $26 \mathrm{ft}$ by 1918, but then began a general decline to less than 13 $\mathrm{ft}$ by 1977 . Some recovery has occurred since 1977 , but the level still was less than $20 \mathrm{ft}$ in 1984 .

Early water levels in the adjacent Ewa ground-water area were estimated to be about $10 \mathrm{ft}$ lower than in the Pearl Harbor ground-water area (Stearns and Vaksvik, 1935), which would be about $22 \mathrm{ft}$ in the lowland areas west of Pearl Harbor. In 1905, the water level was at about $17 \mathrm{ft}$ (fig. 27). A general decline began about 1925 and continued until about 1973 when levels had reached about $12 \mathrm{ft}$ (fig. 27).

There are no early water level records for the Kaimuki ground-water area. Stearns and Vaksvik (1935) estimated a predevelopment water level here of about 35 $\mathrm{ft}$. In 1910, the level was at about $24 \mathrm{ft}$ (fig. 27, table 12). The level declined to about $20 \mathrm{ft}$ during the 1920 's, but recovered to over $25 \mathrm{ft}$ by 1930 . From then until about 1960, the water level fluctuated 3 to $4 \mathrm{ft}$ above and below $25 \mathrm{ft}$. Since 1960, levels have fluctuated about 1 or $2 \mathrm{ft}$ above and below $25 \mathrm{ft}$ and were at $24 \mathrm{ft}$ in 1985 .

\section{NORTHERN OAHU}

Dale (1978) estimated a maximum water level of about $22 \mathrm{ft}$ above sea level for the Mokuleia ground-water area in northern Oahu (fig. 9B). Water level records for well 3409-16 (fig. 27) indicate a level of about $19 \mathrm{ft}$ in 1924 when the record began. Water levels would have been higher in areas inland from this well. The mean annual water level for the period of record for this well is 19.2 
$\mathrm{ft}$; levels have fluctuated about $1 \mathrm{ft}$ above and below this mean value. Maximum water levels in the adjacent Waialua ground-water area (fig. 27) were estimated to be about 12 to $13 \mathrm{ft}$ by Dale (1978). Available records for well 3406-01 indicate a level of about $11.5 \mathrm{ft}$ in 1910 . The mean annual water level in this well for the period of record is $11.4 \mathrm{ft}$; water levels have fluctuated about 1.5 $\mathrm{ft}$ above and below this mean value.

\section{WINDWARD OAHU}

Water levels were estimated to be about $22 \mathrm{ft}$ in 1930 in the Kahuku ground-water area of windward Oahu (Takasaki and Valenciano, 1969). Records for well 405705 (fig. 27) indicate a maximum level of about $16 \mathrm{ft}$ in 1918 , but levels would be higher in areas farther inland.
Water levels declined to about $9.5 \mathrm{ft}$ by 1961 , then recovered to about $12.5 \mathrm{ft}$ by 1980 . The fluctuations are related to ground-water pumpage for sugarcane irrigation, which was discontinued in 1971 when sugarcane production ceased.

\section{SOUTHEASTERN OAHU}

Takasaki and Mink (1982) reported a maximum observed water level of $10.5 \mathrm{ft}$ in the Waialae groundwater area of southeastern Oahu. In 1933, when records began, the water level in well 1646-02 (fig. 27) was about $8.5 \mathrm{ft}$. Over the period of record, levels fluctuated less than $1 \mathrm{ft}$ above and below the mean annual level of 8.25 $\mathrm{ft}$.

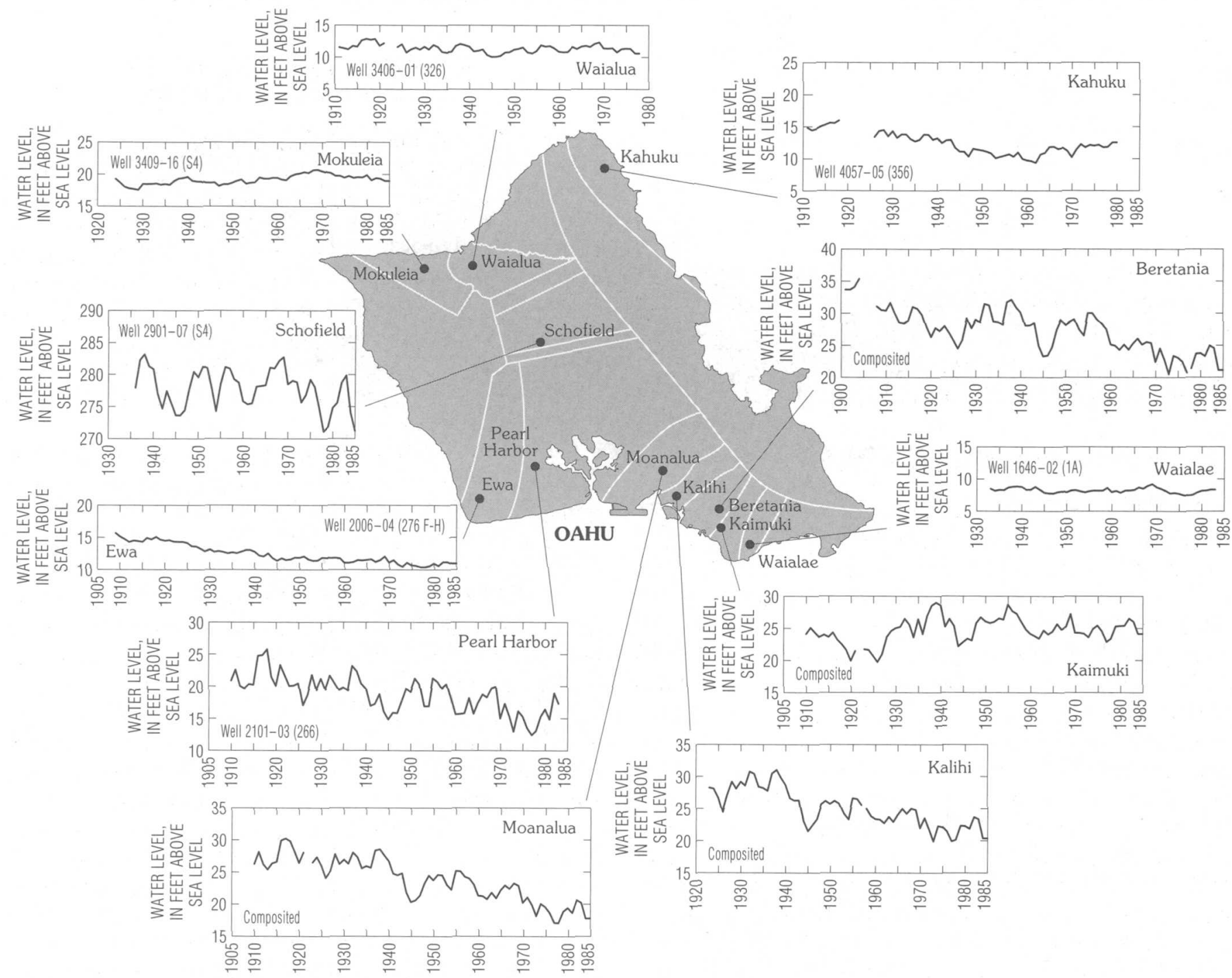

FIGURE 27.-Representative ground-water levels for ground-water areas, island of Oahu. 


\begin{tabular}{|c|c|}
\hline Well number & Dates \\
\hline \multicolumn{2}{|c|}{ Beretania ground-water area } \\
\hline $1849-01$ & $1880-84$ \\
\hline $1849-05$ & 1889-1909 \\
\hline $1849-10$ & $1910-25$ \\
\hline $1851-02$ & $1925-49$ \\
\hline $1849-11$ & $1949-52$ \\
\hline $1851-02$ & $1952-54$ \\
\hline $1849-11$ & $1954-55$ \\
\hline $1851-02$ & $1955-85$ \\
\hline \multicolumn{2}{|c|}{ Kalihi ground-water area } \\
\hline $1952-14$ & $1925-59$ \\
\hline $2052-10$ & $1959-85$ \\
\hline \multicolumn{2}{|c|}{ Moanalua ground-water area } \\
\hline $2153-02$ & $1910-45$ \\
\hline 2153-09 & $1945-85$ \\
\hline \multicolumn{2}{|c|}{ Kaimuki ground-water area } \\
\hline $1749-11$ & $1910-16$ \\
\hline $1749-10$ & $1916-25$ \\
\hline $1749-18$ & $1926-59$ \\
\hline $1749-07$ & $1959-60$ \\
\hline $1749-18$ & $1960-61$ \\
\hline $1749-07$ & $1961-72$ \\
\hline $1749-22$ & $1972-85$ \\
\hline
\end{tabular}

SCHOFIELD AREA

The water level in the Schofield ground-water area was about $278 \mathrm{ft}$ in 1936 when the first well was drilled. The level fluctuated in well 2901-07 (fig. 27) about $7 \mathrm{ft}$ above and below the mean annual level of $277.5 \mathrm{ft}$ for the period of record and was at about $271 \mathrm{ft}$ in 1985.

\section{WATER BUDGET AND GROUND-WATER RECHARGE}

A predevelopment water budget has been estimated for each of the ground-water flow systems of Oahu (Shade and Nichols, 1996). The budget for each flow system is based on somewhat different methodologies, but each budget is designed to provide an easily applied and consistent approach for subsequent investigations. A detailed monthly water budget developed by Giambelluca (1983) for the Pearl Harbor-Honolulu part of the southern Oahu area provided the basis for the method developed during the RASA study to estimate the water budget for the southern and northern Oahu flow systems. Giambelluca (1983) calculated each element of the water budget (precipitation, evapotranspiration, runoff, and ground-water recharge) for different land-use categories in the Pearl Harbor-Honolulu area. These results were used to develop regression relations between precipitation and recharge and runoff. Evapotranspiration was estimated as a residual. A monthly water budget for southeastern Oahu was calculated by Eyre and others (1986) as part of a ground-water flow analysis of that area. Their budget provided the basis for the development of a simple estimation model for the southeastern and western Oahu flow systems similar to that developed for southern Oahu, again based on regression relations between precipitation and recharge and runoff with evapotranspiration estimated as a residual. The water budget for the eastern Oahu flow system was calculated using methods similar to those of Takasaki and others (1969). These methods are described in detail by Shade and Nichols (1996).

These budgets represent the first comprehensive water-budget estimates for all of Oahu. A number of previous studies estimated water budgets or ground-water recharge for various areas, the boundaries of which are not coincident with the area boundaries used in this study, and for various time periods not necessarily equivalent to predevelopment conditions.

\section{PREDEVELOPMENT WATER BUDGET AND GROUND-WATER RECHARGE}

The predevelopment water budgets for each of the ground-water flow systems of Oahu and for the island of Oahu are shown in figures 28 and 29 and are given in table 13. Mean annual ground-water recharge is estimated to have occurred at a rate of about $792 \mathrm{Mgal} / \mathrm{d}$, representing about 40 percent of mean annual precipitation (fig. 29). About 16 percent of mean annual precipitation becomes runoff and 44 percent is lost to evapotranspiration. Nearly the same percentages apply to the hydrologically important noncaprock areas of southern and northern Oahu.

Estimates of predevelopment ground-water recharge to the southern and northern Oahu areas have been made by a number of previous investigators. Attempts to compare recharge estimates developed by the RASA study with those from previous studies (Dale, 1967, 1978; Soroos and Ewart, 1979; Mink, 1980; Giambelluca, 1983, 1986) are complicated because study area boundaries vary among the studies. However, the GISbased (Geographic Information System) water-budget study described by Shade and Nichols (1996) uses widely recognized, readily-defined geographic boundaries for the southern and northern Oahu areas and the smaller ground-water areas encompassed by these larger areas (fig. 30). These geographic boundaries are determined by topographic divides. Although groundwater divides are not necessarily coincident with topographic divides, such boundaries permit easily defined and referenced boundary locations for future studies. Shade and Nichols (1996) estimated direct recharge (recharge by infiltration of precipitation), as well as underflow from the Schofield ground-water area and from the 


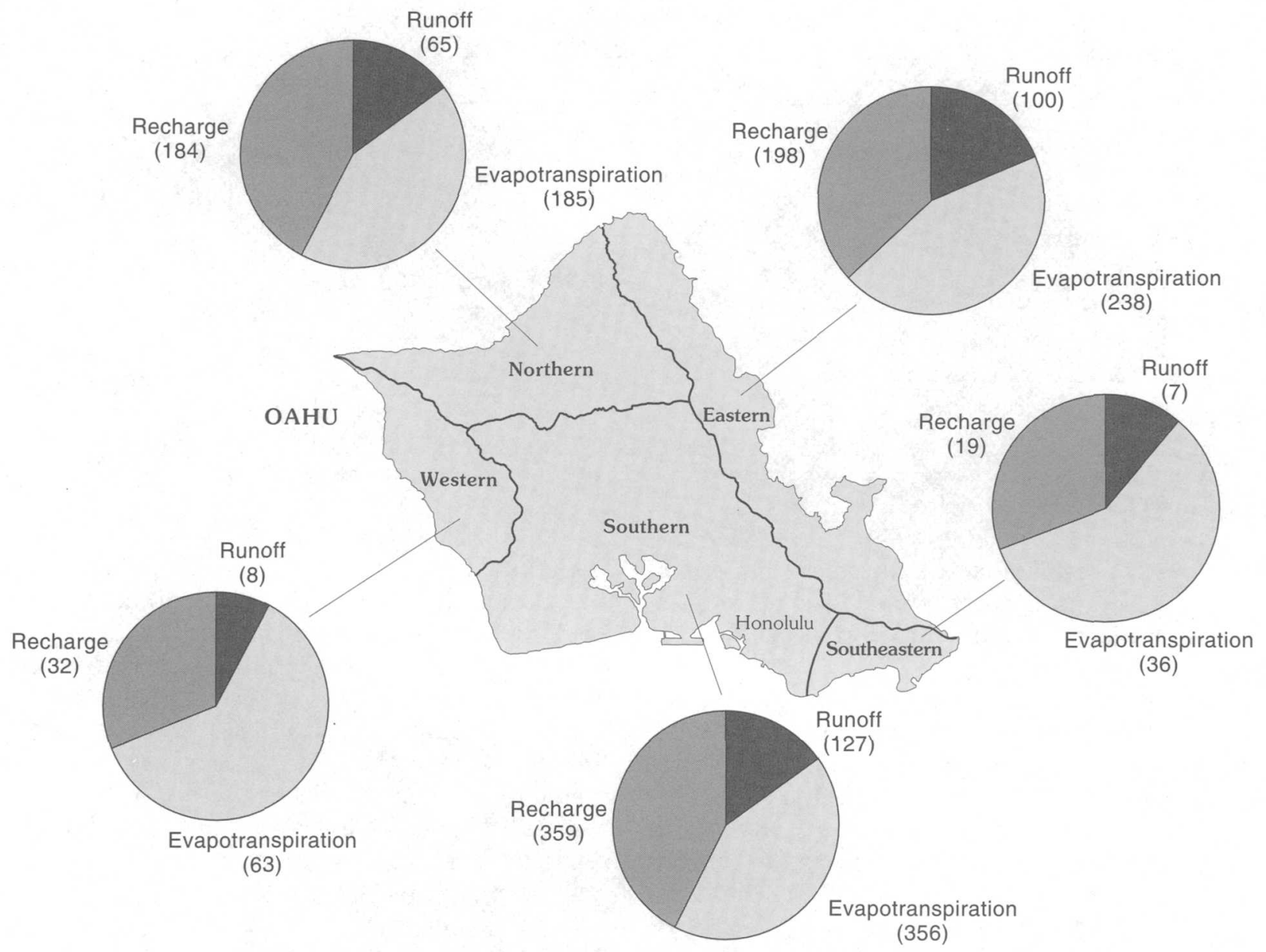

FIGURE 28.-Components of water budget for each ground-water flow system, island of Oahu. Numbers in parentheses are in million gallons per day.

adjacent rift zones, to the various ground-water areas of southern and northern Oahu.

Several previous studies estimated ground-water underflow from the Schofield area to the southern and northern Oahu areas. Dale and Takasaki (1976) estimated ground-water underflow from the Schofield area to be about $120 \mathrm{Mgal} / \mathrm{d}$, with about $96 \mathrm{Mgal} / \mathrm{d}$ going to southern Oahu and about $24 \mathrm{Mgal} / \mathrm{d}$ going to the Waialua area of northern Oahu. Dale (1978) subsequently estimated that about $18 \mathrm{Mgal} / \mathrm{d}$ entered the Waialua area of northern Oahu as underflow from the Schofield area.

As part of the Oahu RASA, Eyre and Nichols (in press), using numerical simulation, estimated about 88 $\mathrm{Mgal} / \mathrm{d}$ of underflow to southern Oahu from Schofield under predevelopment conditions. The water-budget analysis of Shade and Nichols (1996) provides a more comprehensive, though not necessarily more accurate, estimate of predevelopment underflow from the

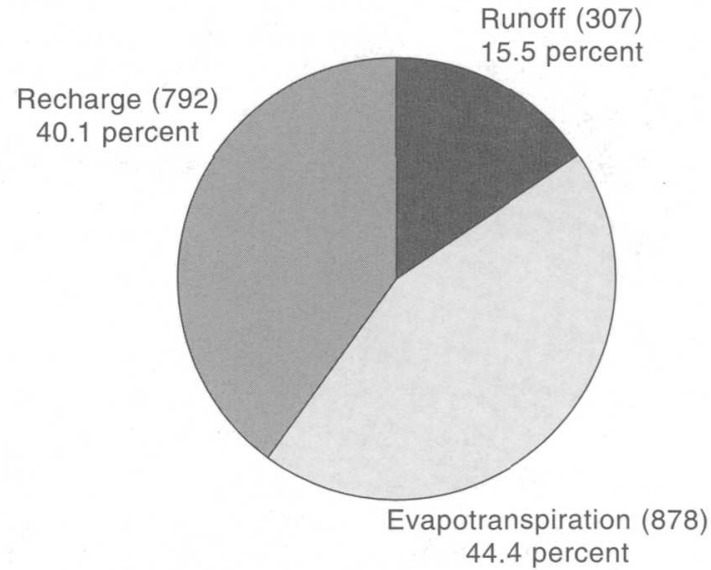

FIGURE 29.-Generalized total water budget, island of Oahu.

Numbers in parentheses are in million gallons per day. 
TABLE 13.-Estimated predevelopment water budget for ground-water flow systems, island of Oahu [All values in million gallons per day]

\begin{tabular}{lrrrr}
\hline Ground-water flow system & Precipitation & Evapotranspiration & Runoff & Recharge \\
\hline Southern & & & & 18 \\
$\quad$ Caprock area & 88 & 63 & 7 & 341 \\
$\quad$ Noncaprock area & 754 & 293 & 120 & 19 \\
Southeastern & 62 & 36 & 100 & 198 \\
Eastern (windward) & 536 & 238 & & \\
Northern & & & 2 & 4 \\
$\quad$ Caprock area & 23 & 17 & 63 & 180 \\
$\quad$ Noncaprock area & 411 & 63 & 8 & 32 \\
Western (Waianae) & 103 & 80 & 9 & 22 \\
Total caprock areas & 111 & 798 & 298 & 770 \\
Total noncaprock areas & 1,866 & 878 & 307 & 792 \\
$\quad$ Total & 1,977 & & &
\end{tabular}

Schofield area and the adjacent rift zones into southern and northern Oahu, together with the quantity of recharge and underflow to the other ground-water areas.

On the basis of the budget analysis of Shade and Nichols (1996), predevelopment ground-water recharge to the noncaprock areas and ground-water underflow to the basalt aquifers of southern and northern Oahu is given in table 14 and shown in figure 30 . Of the 521 $\mathrm{Mgal} / \mathrm{d}$ recharge to the noncaprock areas of southern and northern Oahu, an estimated $199 \mathrm{Mgal} / \mathrm{d}$ flows from the Schofield ground-water area. About 79 $\mathrm{Mgal} / \mathrm{d}$ recharges the Schofield area directly; an estimated $111 \mathrm{Mgal} / \mathrm{d}$ moves into the Schofield area as underflow from the Koolau rift zone, and about 9 $\mathrm{Mgal} / \mathrm{d}$ moves as underflow from the Waianae rift zone. About $103 \mathrm{Mgal} / \mathrm{d}$ is estimated to move as underflow

\begin{tabular}{|c|c|}
\hline Source & $\begin{array}{c}\text { Million gallons } \\
\text { per day }\end{array}$ \\
\hline \multicolumn{2}{|l|}{$\begin{array}{l}\text { Southern ground-water } \\
\text { flow system }\end{array}$} \\
\hline Recharge to noncaprock area & 213 \\
\hline Underflow from southern Schofield area & 103 \\
\hline Underflow from Koolau rift zone & 23 \\
\hline Underflow from Waianae rift zone & 2 \\
\hline Total to southern Oahu & 341 \\
\hline \multicolumn{2}{|l|}{$\begin{array}{l}\text { Northern ground-water } \\
\text { flow system }\end{array}$} \\
\hline Recharge to non-caprock area & 39 \\
\hline Underflow from northern Schofield area & 96 \\
\hline Underflow from Koolau rift zone & 36 \\
\hline Underflow from Waianae rift zone & 9 \\
\hline Total to northern Oahu & 180 \\
\hline
\end{tabular}

from the southern Schofield area into the Pearl Harbor and Ewa ground-water areas in southern Oahu; about $96 \mathrm{Mgal} / \mathrm{d}$ moves as underflow from the northern Schofield area into the Waialua ground-water area in northern Oahu.

Predevelopment recharge and ground-water underflow to the Pearl Harbor ground-water area are estimated to total about $261 \mathrm{Mgal} / \mathrm{d}$ (fig. 30). This assumes that $103 \mathrm{Mgal} / \mathrm{d}$ from the southern Schofield area enters the Pearl Harbor area; some underflow from the Schofield area moves into the adjacent Ewa groundwater area, but probably is less than $1 \mathrm{Mgal} / \mathrm{d}$. Recharge and underflow to the Ewa area are estimated to be about $9 \mathrm{Mgal} / \mathrm{d}$ (fig. 30). Predevelopment recharge to the remaining areas of the southern Oahu flow system totals about $71 \mathrm{Mgal} / \mathrm{d}$ (fig. 30).

Predevelopment recharge and underflow to the Waialua ground-water area in northern Oahu are estimated to total about $104 \mathrm{Mgal} / \mathrm{d}$, to the Kawailoa area about $62 \mathrm{Mgal} / \mathrm{d}$, and to the Mokuleia area about 14 $\mathrm{Mgal} / \mathrm{d}$ (fig. 30). The distribution of predevelopment recharge to the eastern, western, and southeastern Oahu ground-water flow systems is shown in figure 31 .

\section{EFFECTS OF LAND-USE CHANGES}

Land-use changes affect the ground-water system by changing the magnitude and distribution of groundwater recharge. Giambelluca $(1983,1986)$ described the effects of land-use changes on the water budget and ground-water recharge in southern Oahu (excluding the Kaimuki ground-water area) from 1946 to 1975 . The major effect of land-use changes on ground-water recharge is from irrigated agriculture. The excess of applied irrigation water over evapotranspiration leads to an increase in recharge from irrigation-return flow. Giambelluca (1986) suggested that irrigation-return 
flow from furrow-irrigated sugarcane might increase ground-water recharge by as much as 2,000 percent in areas of mean annual precipitation of $20 \mathrm{in}$. or less and by as much as 500 percent in areas of mean annual precipitation of $60 \mathrm{in}$. The magnitude of these increases has been questioned by Eyre and Nichols (in press) and Shade and Nichols (1996); nevertheless, there is no doubt that irrigation return flow will increase groundwater recharge.

Urbanization also leads to changes in the water budget and changes to ground-water recharge. Data given by Giambelluca (1986) indicate that runoff in urbanized areas will increase about 215 percent in areas of mean annual precipitation of $20 \mathrm{in}$. or less, about 340 percent

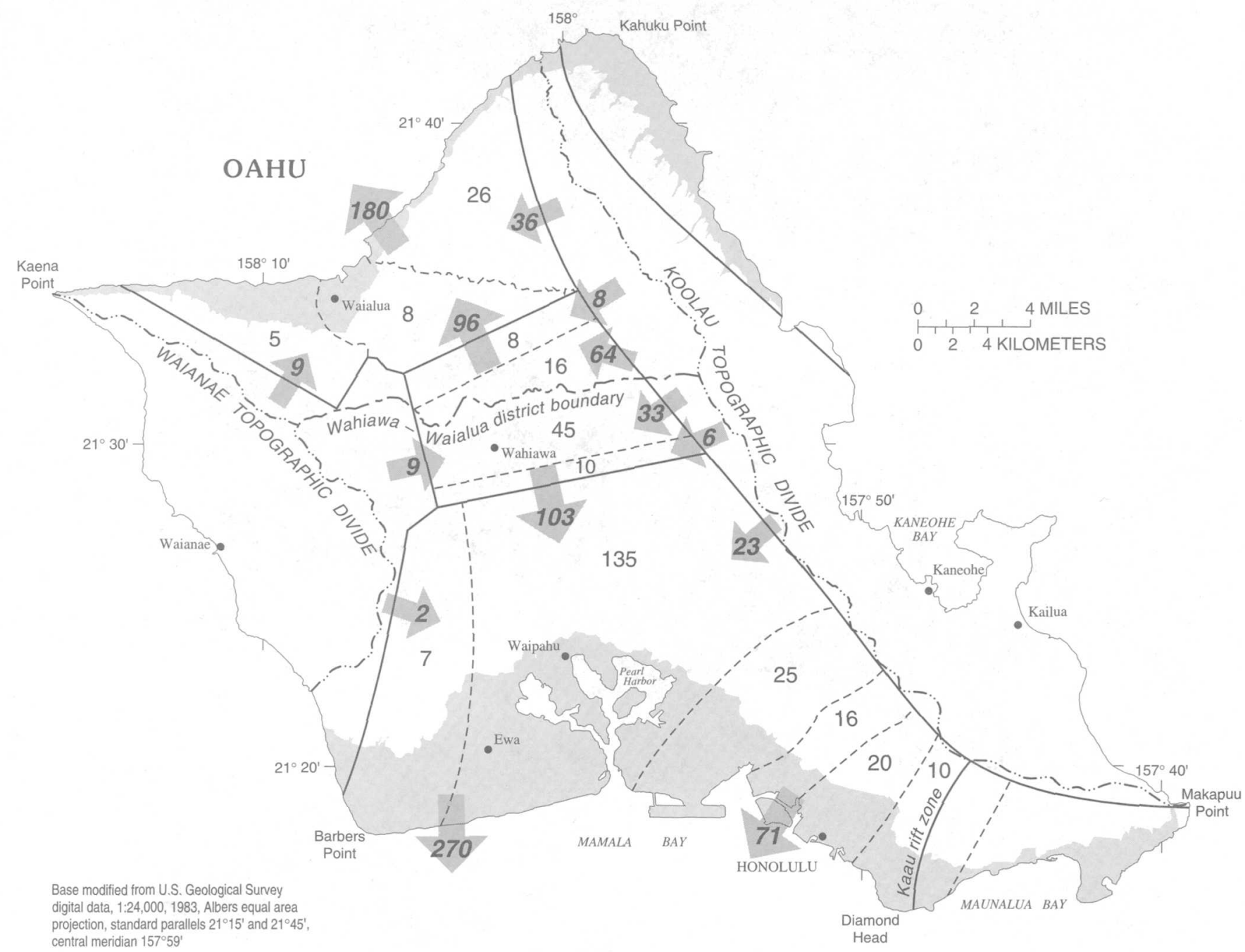

EXPLANATION

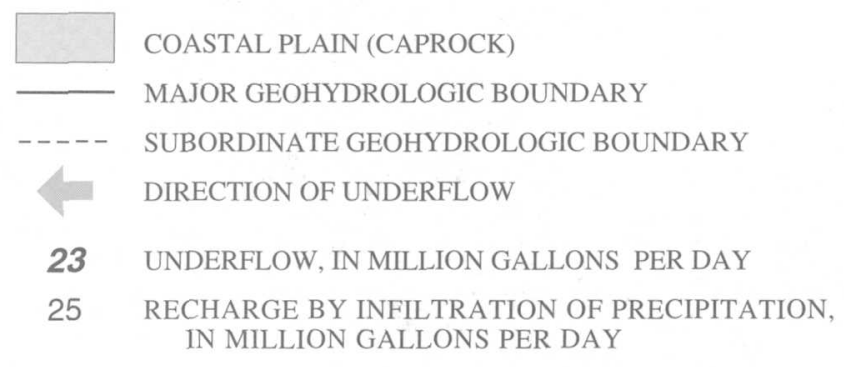

FIGURE 30.-Distribution of estimated predevelopment ground-water recharge to and discharge from the noncaprock areas of the northern and southern ground-water flow systems, island of Oahu. 
for areas with precipitation of about $40 \mathrm{in} / \mathrm{yr}$, and about 265 percent in areas with precipitation of 60 to 80 in/yr. Most of the urbanization on Oahu has been in areas with mean annual precipitation of less than 60 in. Irrigation of lawns in urban areas typically leads to in- creases in evapotranspiration and, in spite of increased runoff, can lead to increases in ground-water recharge. Again, data given by Giambelluca (1986) indicate that, in urban areas with more than $20 \mathrm{in}$. and less than about 60 in. of mean annual precipitation, ground-wa-

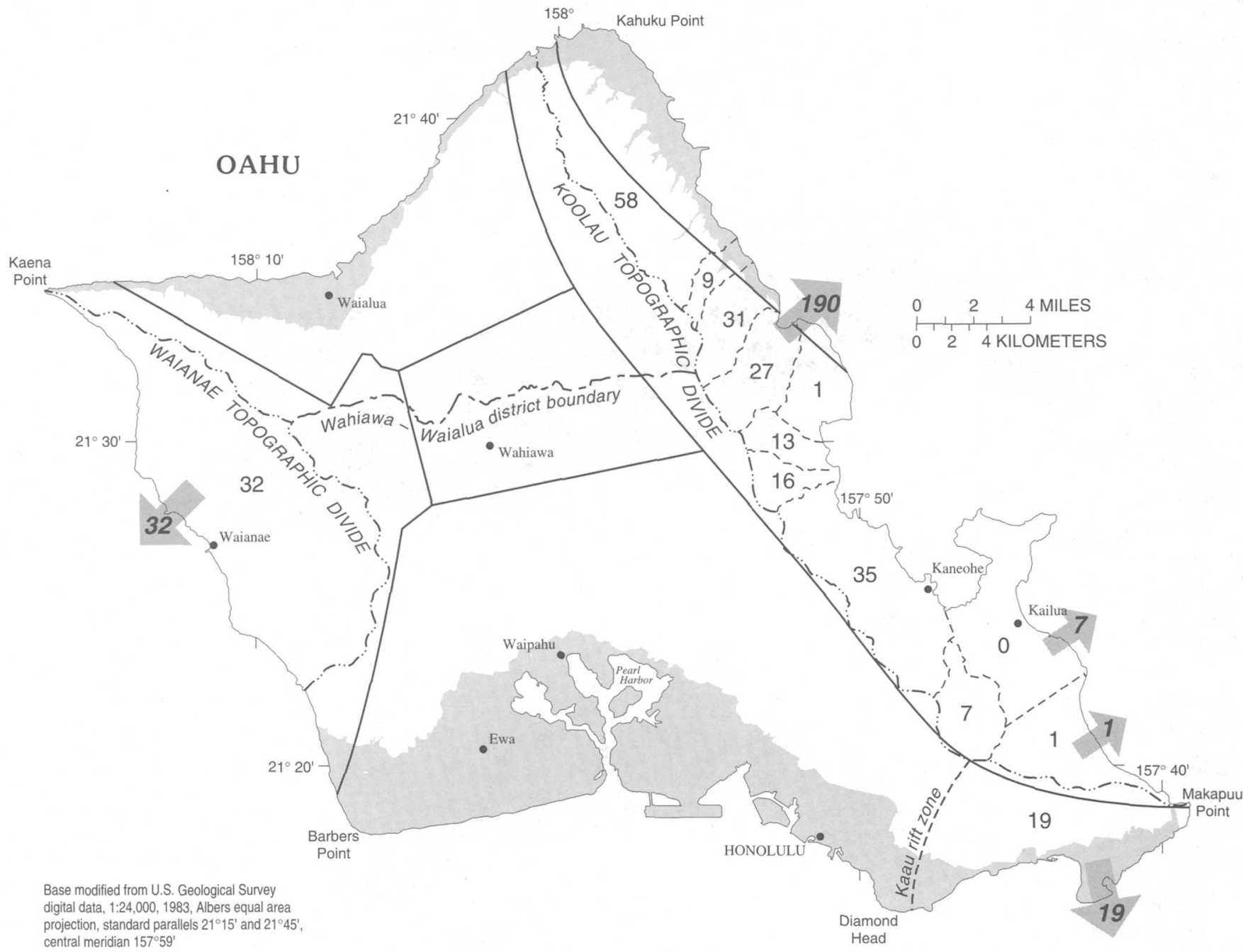

EXPLANATION

COASTAL PLAIN (CAPROCK)

MAJOR GEOHYDROLOGIC BOUNDARY

WINDWARD BASIN BOUNDARY

DIRECTION OF UNDERFLOW

19 UNDERFLOW, IN MILLION GALLONS PER DAY

19 RECHARGE BY INFILTRATION OF PRECIPITATION, IN MILLION GALLONS PER DAY 
TABLE 15.-Estimated water budget for 1980's land use for ground-water flow systems, island of Oahu [All values in million gallons per day]

\begin{tabular}{lcccrr}
\hline $\begin{array}{c}\text { Ground-water } \\
\text { flow system }\end{array}$ & Precipitation & $\begin{array}{c}\text { Applied irrigation } \\
\text { water }\end{array}$ & Evapotranspiration & Runoff & Recharge \\
\hline Southern & & 54 & 87 & 13 & 42 \\
$\quad$ Caprock area & 88 & 33 & 277 & 137 & 373 \\
$\quad$ Noncaprock area & 754 & & 36 & 7 & 19 \\
Southeastern' & 62 & & 238 & 100 & 198 \\
Eastern (windward) & 536 & 12 & 19 & 2 & 14 \\
Northern & 23 & 47 & 194 & 62 & 202 \\
$\quad$ Caprock area & 411 & & 63 & 8 & 32 \\
$\quad$ Noncaprock area & 103 & 146 & 914 & 329 & 880 \\
Western (Waianae) & 1,977 & & & & \\
$\quad$ Total & & & & & \\
\hline
\end{tabular}

'Caprock area insignificant in budget for these areas.

ter recharge increases about 36 percent. For areas with less than about $20 \mathrm{in} / \mathrm{yr}$ of precipitation, ground-water recharge seems to decrease by about 25 percent; in areas with more than $60 \mathrm{in} / \mathrm{yr}$, recharge is largely unchanged, but these areas had experienced little urbanization by 1985 .

The water-budget analysis by Shade and Nichols (1996) estimated a water budget for mid-1980's land uses (table 15). Ground-water recharge to the noncaprock areas of the island had increased to $824 \mathrm{Mgal} / \mathrm{d}$. All of this increase of $54 \mathrm{Mgal} / \mathrm{d}$ above predevelopment rates was estimated to have come as a result of landuse changes in southern and northern Oahu, largely urbanization and agriculture. Estimated recharge increased by $32 \mathrm{Mgal} / \mathrm{d}$ in southern Oahu and by 22 $\mathrm{Mgal} / \mathrm{d}$ in northern Oahu. Of the increase in southern Oahu, $15 \mathrm{Mgal} / \mathrm{d}$ was return flow from irrigated sugarcane and $18 \mathrm{Mgal} / \mathrm{d}$ from nonirrigated pineapple (pineapple reduces natural evapotranspiration); however, there was a reduction of $1 \mathrm{Mgal} / \mathrm{d}$ as a result of urbanization. In northern Oahu, all of the increase was return flow from irrigated sugarcane.

With the introduction of irrigation, sugarcane acreage increased rapidly in the early 1900's to a little over 43,000 acres by 1930 (table 11). These acreages did not change significantly until the 1970's. By 1980 the irrigated acreage had decreased to about 28,500 acres and by 1985 to less than 25,000 acres. More importantly, furrow-irrigated sugarcane acreage had decreased to about 5,600 acres by 1985 (fig. 32), with the remainder irrigated by drip methods. In the noncaprock areas of southern Oahu, there were only about 1,000 acres of furrow-irrigated sugarcane and 4,950 acres of drip-irrigated sugarcane (Shade and Nichols, 1996). This acreage compares to an estimated 10,800 acres of furrowirrigated sugarcane in noncaprock areas of southern Oahu during the 1950's (fig. 33) for which an irrigationreturn flow of about $34 \mathrm{Mgal} / \mathrm{d}$ was estimated by Eyre and Nichols (in press).

\section{ANALYSIS OF GROUND-WATER FLOW IN SOUTHERN OAHU}

The ground-water resources of southern Oahu have been the focus of a number of previous studies (Stearns and Vaksvik, 1935; Wentworth, 1951; Visher and Mink, 1964; Dale, 1967; Soroos and Ewart, 1979; Mink, 1980). About 77 percent of all ground water pumped from the volcanic-rock aquifers of Oahu has been withdrawn from this area. Mean annual predevelopment recharge to the noncaprock areas of southern Oahu, including underflow from adjacent areas, is estimated to be about 44 percent of predevelopment recharge to the noncaprock areas of the island.

The southern Oahu area is part of the southern Oahu ground-water flow system. An analysis of ground-water flow in this system, using numerical simulation, was done as part of the Oahu RASA, and is described by Eyre and Nichols (in press). The analysis used the finiteelement model AQUIFER-SALT (Voss, 1984) to simulate flow in a freshwater lens floating immiscibly on static seawater. Results of the simulation are summarized in this section.

The southern Oahu ground-water flow system is bounded by ground-water and topographic divides along the Waianae crest to the west, the Waialua-Wahiawa district boundary to the north, the Koolau crest to the northeast, and the Kaau rift zone to the southeast (fig. 11). Geologic barriers divide the flow system internally into the southern Schofield ground-water area and the southern Oahu area, which is further divided into the Ewa, Pearl Harbor, Moanalua, and Honolulu groundwater areas (fig. $9 B$; the Honolulu area includes the Kalihi, Beretania, and Kaimuki ground-water areas (fig. $9 B$ ), which were not differentiated for the simulation analysis).

The basalt lava flows of the Waianae and Koolau Volcanoes form permeable aquifers that contain thick lenses of freshwater floating on the underlying and 
more dense seawater. The aquifers are recharged from the infiltration of precipitation, from irrigation-water return flow in irrigated areas, and from ground-water underflow from adjacent areas with higher groundwater levels. Discharge from the aquifers is by pump- age, spring flow, and diffuse leakage through the poorly permeable caprock confining unit.

Ground-water flow in the Ewa ground-water area is contained between the Waianae rift zone on the west and the Waianae confining bed of the Waianae-Koolau
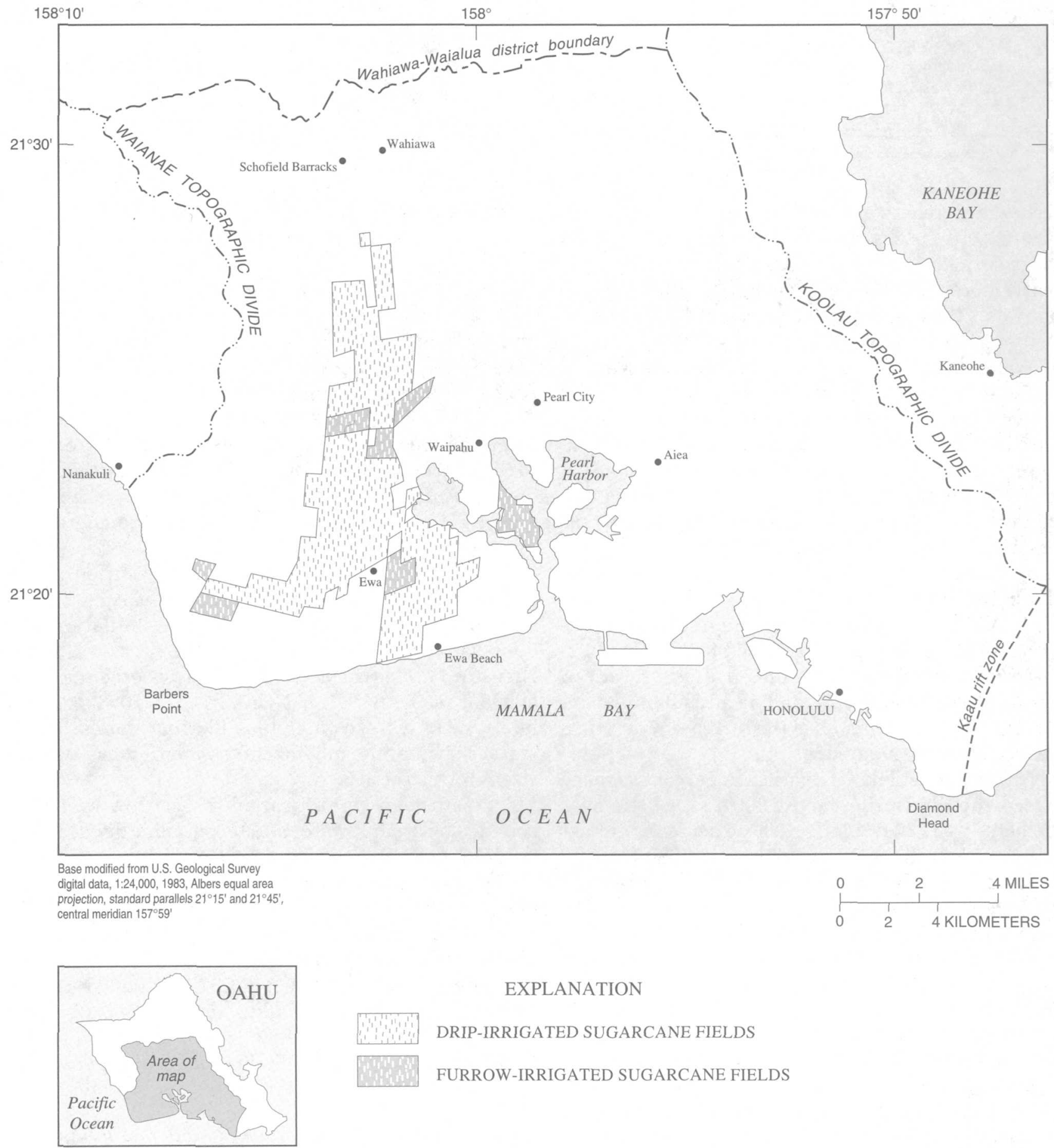

EXPLANATION

DRIP-IRRIGATED SUGARCANE FIELDS

FURROW-IRRIGATED SUGARCANE FIELDS

FiguRE 32.-Areas of sugarcane cultivation in southern Oahu, mid-1980's conditions. 
unconformity (fig. 10) on the east, which generally trends north-south.

In the Pearl Harbor ground-water area, ground water is contained between the southern barrier of the Schofield ground-water area on the north, the Waianae-
Koolau unconformity on the west, the lower reaches of North Halawa Valley on the southeast, and the crest of the Koolau Range on the northeast. The Pearl Harbor and Moanalua ground-water areas are in hydraulic connection across the middle to high reaches of North
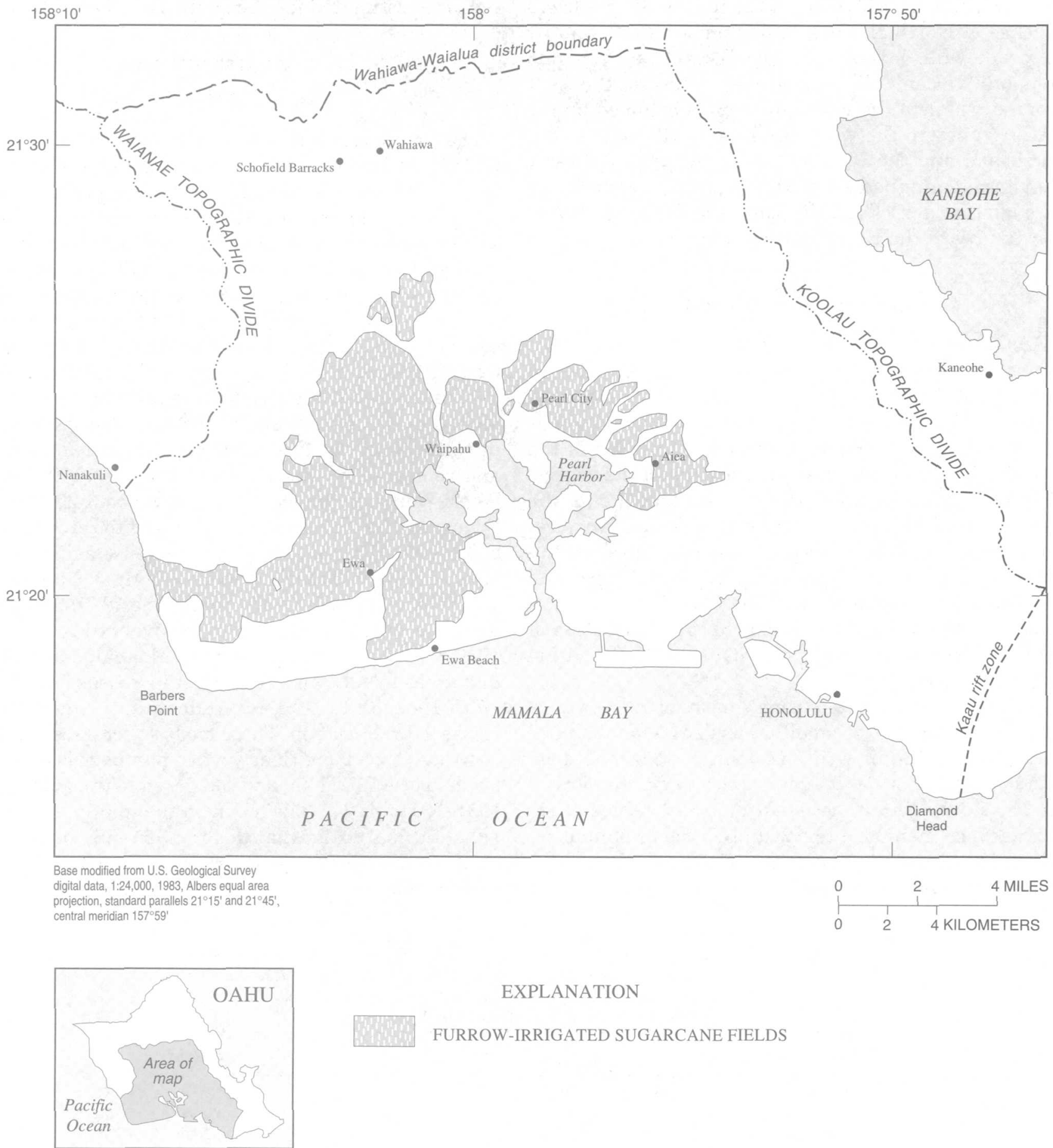

EXPLANATION

FURROW-IRRIGATED SUGARCANE FIELDS

FIGURE 33.-Areas of sugarcane cultivation in southern Oahu, mid-1950's conditions. 
Halawa Stream. Ground-water discharge is concentrated at the Pearl Harbor springs and at pumping centers; most of the remaining water discharges through the caprock as diffuse leakage. A small amount flows into the Ewa area across the ground-water barrier formed by the Waianae-Koolau unconformity.

In the Moanalua area, ground water is contained between the Koolau rift zone on the northeast, the lower reaches of North Halawa Valley on the west, and by deep valley fill, or the combined effects of valley fill and Honolulu volcanic dikes, in Kalihi Valley on the east. Ground water in the Honolulu area is bounded by the Kalihi Valley to the west, the Koolau rift zone to the northeast, and the Kaau rift zone on the east. Water that is not pumped from the Moanalua area leaks through the caprock and discharges to the sea or moves slowly toward the Pearl Harbor area.

\section{GROUND-WATER RECHARGE}

Recharge to the southern Oahu ground-water flow system is derived largely from precipitation, but may be augmented significantly by irrigation-water return flow in agricultural areas. The amount of recharge that reaches the ground-water system is a function of the duration and intensity of precipitation and the volume of irrigation water applied, but also depends on the amount of water lost to surface runoff, evapotranspiration, and soil-moisture storage. These factors are influenced by topography, vegetation type, soil type, and antecedent soil-moisture content. The distribution of ground-water recharge is similar to the distribution of precipitation (fig. 5) except where altered by irrigation or urbanization.

Recharge was estimated using a mean monthly waterbalance approach over small areas (T.W. Giambelluca, University of Hawaii, written commun., 1985) that took into consideration land-use practices and changes in land use over time. The mean monthly values of recharge were then used to calculate a mean annual recharge for each land-use category. Generalized recharge to the aquifers in noncaprock areas of southern Oahu for predevelopment land use and for average 1950's land-use conditions are given in table 16 . Recharge estimates from the water balance study of Shade and Nichols (1996) indicate somewhat more recharge (341 $\mathrm{Mgal} / \mathrm{d}$ ) than the recharge ( $305 \mathrm{Mgal} / \mathrm{d}$ ) estimate developed by Eyre and Nichols (in press), but the totals are within about 10 percent. The major difference is the recharge estimated for the southern Schofield area.

\section{GROUND-WATER DISCHARGE}

PUMPAGE

The first successful flowing artesian well was drilled in 1879 at Honouliuli (Visher and Mink, 1964, p. 31). The well penetrated the caprock and tapped the underlying basalt and confined basal ground water. Before 1900 , ground water, which was used mostly in the lowland areas of southern Oahu, was obtained from these flowing wells. By about 1900 , large pumps were installed in deep wells to provide irrigation water for sugarcane irrigation at higher altitudes. Total pumpage from the volcanic-rock aquifers in the southern Oahu area increased from about $20 \mathrm{Mgal} / \mathrm{d}$ in 1901 to 165 $\mathrm{Mgal} / \mathrm{d}$ by 1912 (Eyre and Nichols, in press). Pumpage increased to about 175 to $200 \mathrm{Mgal} / \mathrm{d}$ in the mid-1920's and remained at this level until about 1940. During World War II, pumpage increased to about $250 \mathrm{Mgal} / \mathrm{d}$. Following the war, pumpage returned to rates of about $200 \mathrm{Mgal} / \mathrm{d}$. Pumpage began to increase again around 1959 and by 1970 reached about $275 \mathrm{Mgal} / \mathrm{d}$, a rate that generally was maintained through the 1970's. Pumpage from the Ewa area has been relatively constant since 1920 , whereas pumpage from the Moanalua and Honolulu areas has shown only modest increases from 192140 to $1941-60$ to $1961-80$, reflecting the general increase in urbanization. These modest increases are demonstrated even more clearly when pumpage is averaged for the period 1921-50 and compared to the average for 1951-58 (table 17). The mean annual pumping rate for $1921-50$ is $194.7 \mathrm{Mgal} / \mathrm{d}$; for $1951-58$, it is 202.8 $\mathrm{Mgal} / \mathrm{d}$, which is only 104 percent of the $1921-50$ mean annual rate.

\begin{tabular}{|c|c|c|c|}
\hline \multicolumn{4}{|c|}{$\begin{array}{l}\text { TABLE 16.-Estimated ground-water recharge for predevelopment } \\
\text { land use used in the numerical analysis of ground-water flow in } \\
\text { ground-water flow system in the noncaprock areas of sout } \\
\left.\text { [Mgal/d, million gallons per day; } \mathrm{mi}^{2} \text {, square mile }\right]\end{array}$} \\
\hline Ground-water area & $\begin{array}{l}\text { Predevelopment } \\
\text { (Mgal/d) }\end{array}$ & $\begin{array}{c}\text { Average 1950's } \\
\text { (Mgal/d) }\end{array}$ & Area $\left(\mathrm{mi}^{2}\right)$ \\
\hline Ewa... & $\ldots 7.6$ & 11.9 & 30.56 \\
\hline Pearl Harbor............ & $\ldots \ldots 141.9$ & 173.2 & 79.36 \\
\hline Moanalua and Honolu & $\ldots \ldots \ldots 67.7$ & 67.7 & 34.09 \\
\hline Schofield.............. & .....887.9 & 92.5 & 43.70 \\
\hline Total & 305.1 & 345.3 & 187.71 \\
\hline
\end{tabular}


TABLE 17.-Comparison of mean annual ground-water pumpage, island of Oahu, 1921-50 and 1951-58 [All values in million gallons per day]

\begin{tabular}{ccc}
\hline Area & $1921-50$ & $1951-58$ \\
\hline Ewa & 21.2 & 23.5 \\
Pearl Harbor & 146.5 & 146.8 \\
Moanalua & 12.2 & 19.7 \\
Honolulu & 14.8 & 12.8 \\
Total & 194.7 & 202.8 \\
\hline
\end{tabular}

PEARL HARBOR SPRINGS

Along the coastal area of southern Oahu, the seaward flow of ground water is impeded by the caprock confining unit. Ground-water discharge from this area occurs as diffuse leakage through the caprock and as spring flow over the top and through openings or breaks in the caprock. For about $5 \mathrm{mi}$ along the north shore of Pearl Harbor from near Aiea to southwest of Waipahu, ground water flows into Pearl Harbor along a nearly continuous zone of springs (fig. 12). Seventy percent of the natural discharge from the Pearl Harbor area occurs through the large springs at Kalauao, Waiau, Waimano, Waiawa, and Waikele.

Estimated discharge from these springs was about 187 $\mathrm{Mgal} / \mathrm{d}$ for predevelopment conditions and about 95 $\mathrm{Mgal} / \mathrm{d}$ for average 1950's conditions. Additional discharge from the aquifer system occurs as diffuse leakage through the caprock. The rate of this discharge is a function of the head in the basalt beneath the caprock and the hydraulic conductivity of the caprock. Given a predevelopment recharge rate of about $305 \mathrm{Mgal} / \mathrm{d}$ and a predevelopment spring discharge rate of about 187 $\mathrm{Mgal} / \mathrm{d}$, predevelopment discharge as leakage through the caprock is estimated to be about $118 \mathrm{Mgal} / \mathrm{d}$.

\section{SOUTHERN OAHU GROUND-WATER FLOW SYSTEM}

\section{CONCEPTUAL MODEL}

The conceptual model and the measured and calculated variables that are incorporated into the numerical model are summarized as follows:

1. The southern Oahu ground-water flow system occurs in the lava flows of the Waianae and Koolau volcanics as a lens of freshwater floating on denser saltwater. The bounding rift zones and flow barriers separate the flow system from ground-water flow systems of adjacent areas. Ground-water inflow comes only from the Schofield area to the north. Barriers of low permeability divide the flow system into the south Schofield, Ewa, Pearl Harbor, Moanalua, and Honolulu groundwater areas. The hydraulic conductivity of the Schofield barrier was estimated from the flow rate $(88 \mathrm{Mgal} / \mathrm{d})$ and head gradient across the barrier $(255 \mathrm{ft}$ over a dis- tance of $3,000 \mathrm{ft}$ ), and is approximately $0.26 \mathrm{ft} / \mathrm{d}$. No data exist from which to estimate the hydraulic conductivity of the other barriers; those values were determined through calibration of the numerical model.

2. Ground-water flow through each area equals the areal recharge rate plus underflow between areas as determined by model calibration.

3. Ground water flows from the higher altitudes inland to the coastal plain areas. The caprock confining layer along the coastal plain restricts ground-water discharge to the sea. Before the development of groundwater resources, recharge to the flow system was from precipitation and discharge was by spring flow, diffuse leakage through the caprock, and evapotranspiration (in areas of shallow ground water). Since development began, recharge has been augmented by irrigation return flow, and discharge has been increased by ground-water pumpage. Discharge from the modeled area equals the sum of measured pumpage, estimated spring flow, and diffuse leakage through the caprock.

4. The value of aquifer hydraulic conductivity is constant over the study area, between $1,000 \mathrm{ft} / \mathrm{d}$ and 5,000 $\mathrm{ft} / \mathrm{d}$, and may be several times greater along the direction of lava flows than perpendicular to the flow direction (within the horizontal plane of the lava flows).

5 . The study area has experienced two periods of steady-state or approximate steady-state conditions when mean water levels, and possibly the mean position of the transition zone between freshwater and saltwater, were in equilibrium with the mean pumping and recharge rates of those periods. These periods are the period before aquifer development began (predevelopment) and the period from about 1951 to 1958 (1950's).

\section{ASSUMPTIONS AND LIMITATIONS FOR NUMERICAL ANALYSIS}

Several assumptions are necessary to reduce the complexity of the problem to match the constraints of the available numerical methods. These simplifying assumptions limit the ability of the model to address certain problems or situations. The assumptions used in developing the simulation model of ground-water flow in the southern Oahu area are as follows:

1. Ground-water flow is two-dimensional and is parallel to the horizontal plane of the aquifer; vertical flow does not occur.

2. The aquifer thickness is a function of the height of freshwater above sea level in accordance with the Ghyben-Herzberg relation.

3. The freshwater-saltwater interface is sharp and well defined and responds instantly to changes in freshwater head.

4. Pumping rates are average rates and are constant for the period of simulation. 
5. Recharge rates are average rates and are constant for the period of simulation.

6 . Values of hydraulic conductivity for each element are average values for the study area and are constant throughout the area except where geohydrologic barriers occur.

The limitations to the model include the following:

1. A numerical model is unable to simulate all the complexities of a natural system. As a result, solutions are an approximation.

2 . The model is based on the interpretation of relatively sparse water-level and geologic data. As new data are obtained, particularly from inland areas for which no water-level data are presently available, the groundwater flow field and the nature of the various geohydrologic barriers and their effect on ground-water flow may need to be reevaluated.

3 . The model does not adequately simulate short-term water-level fluctuations or describe the flow in the vicinity of a pumping well. This limitation results primarily from the areally averaged results calculated by the model and from the assumption of instantaneous, hydrostatic equilibrium used to calculate the depth of the bottom of the freshwater lens. If simulations of rapid fluctuations in water level are attempted, this assumption causes significant error in calculated lens thickness because, in reality, the lens bottom has not had time to achieve equilibrium with the water table. The error is diminished for longer period fluctuations. Over a period of several years the bottom of the lens approaches hydrostatic balance (Eyre and others, 1986).

4. The model does not simulate saltwater contamination caused by upconing beneath a pumping well. This can be approximated by analytical solutions when the pumping rate, well depth, aquifer hydraulic conductivity, and thickness of the freshwater lens are known.

5 . The caprock boundary was modeled as a homogeneous hydrologic confining unit, using a single set of parameters to reproduce observed conditions. The model does not accurately simulate the freshwater-saltwater interface in the vicinity of the caprock, and is not intended to be used to simulate stress much different from the range of stresses for which the model was calibrated.

6 . Few observations of the freshwater-saltwater interface were available for model calibration. The model is not intended to be used to predict the location and behavior of the interface for stress conditions much different from those for which the model is calibrated, especially in areas overlain by the caprock.

\section{RESULTS}

The results of initial model calibration indicated that regional hydraulic conductivities were anisotropic, with the direction of maximum hydraulic conductivity more nearly parallel to the direction of lava flows and the direction of minimum hydraulic conductivity more nearly perpendicular to the direction of the flows. Errors in the distribution of estimated recharge and caprock discharge in the Pearl Harbor area also might affect the direction of hydraulic gradients. This possibility was investigated by changing recharge and discharge distributions, but simulated gradient directions were not sensitive to these changes.

Water levels simulated by the model commonly were within about $1.5 \mathrm{ft}$ of observed heads. In the western part of the Pearl Harbor area, the simulated heads were 0.7 to $2.4 \mathrm{ft}$ too low, and, in the eastern part of the area, they were as much as $2.2 \mathrm{ft}$ too high. These differences may be the result of errors in the estimated rate or distribution of recharge, but are believed to be the result of errors in the simulated directions of maximum and minimum hydraulic conductivity in the basalt aquifer. These results were considered to be sufficiently accurate for the purposes of this study.

The conceptual model of the hydrodynamics of the southern Oahu ground-water flow system was not altered significantly by the results of steady-state simulation. During the calibration process, it was determined that there was considerable anisotropy in aquifer hydraulic conductivity in the basalt aquifers. It also was determined that the magnitude and distribution of hydraulic conductivity of the caprock confining unit was not uniform and varied from one subarea to another. Finally, after considerable analysis, it was decided that the original estimate of irrigation return flow was too large.

The initial steady-state simulation model assumed a uniform hydraulic conductivity for the basalt aquifers of $2,000 \mathrm{ft} / \mathrm{d}$. This was changed so that a maximum hydraulic conductivity of $4,500 \mathrm{ft} / \mathrm{d}$ was assigned to a direction generally perpendicular to the Waianae crest for the Waianae volcanics and generally perpendicular to the Koolau crest for the Koolau Basalt. A minimum hydraulic conductivity of $1,500 \mathrm{ft} / \mathrm{d}$ was assigned to the direction perpendicular to the direction of maximum hydraulic conductivity. This had the effect of assigning larger values of hydraulic conductivity to the directions parallel to the flow directions of lavas from the two eruptive centers.

The caprock confining unit was represented in the initial model by a seaward-thickening wedge with a uniform hydraulic conductivity of $1 \times 10^{-1} \mathrm{ft} / \mathrm{d}$. During calibration, the hydraulic conductivity for each of the ground-water areas of the southern Oahu ground-water flow system was modified, although the change also may imply a change in confining-layer thickness. The calibrated steady-state model has the following caprock/ 
saprolite hydraulic-conductivity values: Ewa area, 1.25 $\mathrm{x} 10^{-1} \mathrm{ft} / \mathrm{d}$; Pearl Harbor area, $1 \times 10^{-2} \mathrm{ft} / \mathrm{d}$; and Moanalua and Honolulu areas, $6.6 \times 10^{-2} \mathrm{ft} / \mathrm{d}$. These values represent not more than an order of magnitude change in the original estimates for caprock hydraulic conductivity.

A major result of the analysis was a reevaluation of estimated irrigation return flow for 1950's conditions. The original estimated return flow for the period 195158 was about $107 \mathrm{Mgal} / \mathrm{d}$, of which about $87 \mathrm{Mgal} / \mathrm{d}$ was from furrow-irrigated sugarcane and the remainder from other irrigation and from reduced evapotranspiration in areas of pineapple cultivation. The revised estimate, based on the model calibrated for both predevelopment and 1950's conditions, is $40 \mathrm{Mgal} / \mathrm{d}$ return flow from all sources. Of this, about $35 \mathrm{Mgal} / \mathrm{d}$ is estimated to be from furrow-irrigated sugarcane.

The assumptions of the model are important to the understanding of the results of the analysis. Perhaps the most significant and limiting assumption is that the underlying freshwater-saltwater interface is sharp and well defined and responds instantly to changes in freshwater head. This assumption severely limits the utility of the model to perform satisfactory simulations of short-term transient conditions; equilibration of the interface may take as long as 60 to 80 years following a change in pumping rate, although 80 to 90 percent of the equilibration will probably be achieved in about 20 years. The assumption of a sharp interface does not allow use of the model to predict the location of nonpotable saline water because the interface is, in reality, a transition zone of undetermined thickness. Proper determination of the effects of pumpage on the transition zone must be evaluated separately from the representations provided by this model.

The analysis clearly demonstrated that water levels in the aquifers of southern Oahu are strongly correlated with recharge and discharge. The results of this model are reliable only for estimating steady-state conditions for which reliable estimates of recharge and discharge are known. Given the rapidly changing nature of the recharge regime in southern Oahu resulting from urbanization, it is inappropriate to use these recharge data in this model together with estimates of future pumpage to obtain an estimate of future water levels. For much the same reasons, it is inappropriate to use this model to attempt to determine a value for sustainable yield without consideration being given to the land use and recharge conditions for which the values of sustainable yield would apply. A given sustainable yield will depend in large measure on the extent to which a given recharge rate can be sustained. Sustainable yield also involves the question of water quality, specifically salinity, which is not addressed in this model.
Several issues remain unresolved or incompletely resolved. The direction of maximum hydraulic conductivity in the basalt aquifers of Pearl Harbor area warrants additional analysis. The data available for the simulation analysis did not justify further pursuit of this issue. The reason for the overestimation of irrigation return flow is uncertain and was beyond the scope of the study. Resolution of this problem and a better estimate of the distribution of this component of recharge will help in developing a better definition of the distribution of hydraulic conductivity and direction of maximum hydraulic conductivity in the aquifer. The wedge geometry of the caprock was chosen to simulate increased resistance to freshwater discharge in the seaward direction. A slab of rather uniform thickness with a decreasing hydraulic conductivity and increasing saltwater head in the seaward direction also would simulate the increased resistance to discharge. Determination of the most appropriate caprock configuration will require a more detailed analysis of the geohydrology of the caprock and underlying saprolite than was possible during the RASA study.

\section{SUMMARY AND CONCLUSIONS}

Oahu is the third largest of the eight major islands of the Hawaiian islands and supported a population of nearly 850,000 people in 1990 . Sixty-eight percent of all water, including seawater, used for municipal, industrial, commercial, and agricultural purposes on Oahu is ground water. Oahu is the most populous of the Hawaiian islands, covering $593 \mathrm{~m}^{2}$ of land area, but much of this land area is forested or cultivated. Most of the population is concentrated in urban centers near the coast.

The subtropical climate of Oahu is characterized by mild temperatures and moderate to high humidity, which varies diurnally from about 60 to 90 percent. There is extreme variation in precipitation over short distances ranging from about $25 \mathrm{in} / \mathrm{yr}$ in Honolulu to as much as $275 \mathrm{in} / \mathrm{yr}$ along the highest part of the crest of the Koolau Mountains. A pronounced orographic pattern of cloud cover and precipitation is established as moist oceanic air is forced up and over the mountainous terrain by persistent tradewinds.

Oahu and the other Hawaiian islands are the exposed peaks of large volcanic mountain ranges, most of which lie beneath the sea, that constitute the Hawaiian Ridge. The island of Oahu is formed by the remnants of two coalesced shield volcanoes, the Koolau Volcano to the east and the Waianae Volcano to the west. The Waianae Volcano is older than the Koolau; both volcanoes likely erupted concurrently during at least part of their active lifespans. The shield-building lavas emanated mainly from prominent rift zones of the two volcanoes. Near the 
end of the growth of the shield, the summits of the volcanoes collapsed and formed calderas. After a long period of subsidence and erosion, eruptive activity resumed at scattered vents at the southern ends of the Koolau and Waianae Ranges.

Although most Hawaiian volcanic rocks have similar basaltic composition, their modes of emplacement result in a variety of physical properties that govern their hydraulic properties. The volcanic rocks are divided into four groups: (1) lava flows, (2) dikes, (3) pyroclastic deposits, and (4) saprolite and weathered basalt. Stratified sequences of thin-bedded lava flows form the most productive aquifers in Hawaii. Lava flows on Oahu, as well as the other islands of Hawaii, are mainly of two textural types - pahoehoe and aa. Dikes are thin, nearvertical sheets of massive intrusive rock that typically contain only fracture permeability. Where dikes intrude lava flows, they inhibit ground-water flow principally in the direction normal to the plane of the dike. Pyroclastic deposits include ash, cinder, and spatter. They are essentially granular with porosity and permeability similar to that of granular sediments with a similar grain size and degree of sorting. Weathering of basaltic rocks in the humid, subtropical climate of Oahu alters igneous minerals to clays and oxides and reduces the permeability of the parent rock. Saprolite is weathered material that has retained textural features of the parent rock.

Estimates of aquifer properties on Oahu have been made by several methods, including laboratory measurements on rock samples, local- and regional-scale aquifer tests, and numerical models of regional groundwater flow. Most estimates of aquifer hydraulic properties on Oahu have been derived from aquifer tests. The thickness of the volcanic-rock aquifers of Oahu is not known, but probably is at least several thousand feet. This has important implications for estimates of hydraulic conductivity and transmissivity derived from aquifer tests because transmissivity is a function of hydraulic conductivity and aquifer thickness. The lack of a definable aquifer thickness and the partial penetration of wells introduce ambiguity to estimates derived from aquifer tests. A number of investigators have equated aquifer thickness to the thickness of freshwater flow or the zone of effective inflow to the well. Others have assumed it is equal to the thickness of the freshwater lens. Estimates of hydraulic conductivity for dike-free lavas, based mostly on analysis of aquifer test data using the Theis and Thiem equations, tend to fall within about one order of magnitude, from about 500 to about $5,000 \mathrm{ft} / \mathrm{d}$. Estimates of specific yield range from about 1 to 20 percent; most of the values lie within a narrow range of about 5 to 10 percent. Estimates of confined-storage coefficient typically are somewhat higher than the range of $5 \times 10^{-3}$ to $5 \times 10^{-5}$ cited for confined aquifers.

Sedimentary rocks on Oahu are of both marine and terrestrial origin and have wide ranges in composition, grain size, and degree of induration. Marine sedimentary rocks are mostly calcareous and include coralalgal reefs, coralline rubble and sand, and lagoonal sand and marl. Terrestrial sedimentary deposits include deposits of talus, colluvium, and alluvium ranging in grain size from estuarine mud to boulder.

The mode of occurrence of ground water on Oahu is determined by the type and character of the rocks and by the presence of geohydrologic barriers. The primary modes of freshwater occurrence in Oahu are as a basal lens of fresh ground water floating on saltwater, as dikeimpounded ground water, and as perched ground water. Basal ground water is water that lies beneath the water table, below which all permeable rocks are saturated. The freshwater head in a basal-water lens is near sea level. On Oahu, basal ground water occurs both in volcanic-rock aquifers and in aquifers in the sedimentary deposits under confined and unconfined conditions. The thickness of the freshwater lens depends on recharge, aquifer permeability, and the presence or absence of confinement in the shoreward discharge areas. Steeply dipping volcanic dikes impound freshwater to great heights within the rift zones of the Waianae and Koolau Volcanoes. The dikes are barriers to the lateral flow of ground water and impound water in compartments, or reservoirs, of permeable lavas. Perched ground water may occur in the unsaturated zone, which is several hundred feet thick throughout much of Oahu and may be more than $1,000 \mathrm{ft}$ thick in places. A large body of high-level water occurs beneath the Schofield area of central Oahu, and its occurrence and behavior do not resemble dike-impounded or perched types of high-level water. Saltwater occurs at depth throughout much of the island.

Oahu is underlain by a regional aquifer system composed of two principal aquifers, the Waianae aquifer in the Waianae Volcanics and the Koolau aquifer in the Koolau Basalt, that are subdivided into well-defined areas by geohydrologic barriers. The aquifers are separated by a regional confining unit, the Waianae confining unit, formed along the Waianae-Koolau unconformity. In some coastal areas, caprock overlies and confines the aquifers, impeding freshwater discharge and impounding basal water to thicknesses of as much as $1,800 \mathrm{ft}$.

The areal hydraulic continuity of the aquifers of Oahu is interrupted in many places by steeply dipping geohydrologic barriers that cut across the layered lavas at 
high angles. There are two types of barriers: those of structural origin, which are mainly intrusive rocks, but also may include other types of massive rock, such as ponded lavas; and those of surficial origin, which are mainly valley-fill deposits, but also may include weathered geologic material. These barriers impede and divert ground-water flow. In the Schofield area and the rift zones, these barriers impound ground water to much greater heights than would be possible in their absence.

The island of Oahu has been divided into seven major ground-water areas based on the occurrence of deepseated, structural geohydrologic barriers. Hydraulic continuity within these seven areas generally is high, and the potentiometric surface is smoothly continuous, except in rift zones where dikes cause numerous local discontinuities and where internal barriers cause further disruptions. The Koolau rift zone along the eastern side of the island and the Waianae rift zone to the west constitute two of the major ground-water areas. The north-central Oahu area is divided into three smaller ground-water areas: the Mokuleia, Waialua, and Kawailoa areas. The Schofield ground-water area encompasses much of the Schofield area in central Oahu. The southern Oahu area is divided into six smaller ground-water areas: the Ewa, Pearl Harbor, Moanalua, Kalihi, Beretania, and Kaimuki areas. The southeastern Oahu area is divided into two smaller ground-water areas: the Waialae and Wailupe-Hawaii Kai ground-water areas. Along the northeast coast of windward Oahu is the Kahuku ground-water area.

The aquifers of Oahu contain shallow freshwater and deeper saltwater flow systems. There are five fresh ground-water flow systems: (1) the eastern, (2) northern, (3) southern, (4) western, and (5) southeastern Oahu flow systems. Meteoric freshwater flow diverges from ground-water divides that lie somewhere within the Waianae and Koolau rift zones, forming an interior flow system in central Oahu, exterior flow systems in western (Waianae area) and eastern (windward) Oahu, and a small flow system in southeastern Oahu. The exact location of the ground-water divides is not known, but they commonly are assumed to coincide with topographic divides for purposes of discussion and analysis. The development of ground-water on Oahu began when the first well was drilled near Honouliuli in the summer of 1879 . By 1890,86 wells had been drilled on the island. From about 1891 to about 1910, development increased rapidly with the drilling of a large number of wells for irrigation of sugarcane in southern and northern Oahu and in the Kahuku area of windward Oahu. By 1930, at least 673 wells had been drilled on Oahu for all uses; of these, 62 are still in use for public supply. By 1985 , at least 1,635 wells, shafts, and tunnels had been drilled on Oahu for the development of groundwater resources. Of these, 445 have been abandoned and destroyed, another 335 were unused, and there were 1,190 existing wells, tunnels, and shafts.

Before 1900, few records of ground-water pumpage were kept, and from 1901 to 1910, the available records are incomplete. Ground-water pumpage from the volcanic-rock aquifers from 1901 to 1910 averaged at least $88.9 \mathrm{Mgal} / \mathrm{d}$. This pumpage increased to $159.8 \mathrm{Mgal} / \mathrm{d}$ during the following decade and by the decade ending in 1930 averaged $216.6 \mathrm{Mgal} / \mathrm{d}$. Much of the mean daily pumpage of $221.7 \mathrm{Mgal} / \mathrm{d}$ in 1930 was for irrigation of sugarcane, which covered 43,277 acres. Ground-water pumpage for all uses increased from an average of 320.4 $\mathrm{Mgal} / \mathrm{d}$ in 1941 to $413.3 \mathrm{Mgal} / \mathrm{d}$ in 1970 , but decreased to $318 \mathrm{Mgal} / \mathrm{d}$ by 1980 .

Ground-water use averaged about $394 \mathrm{Mgal} / \mathrm{d}$ from all sources in 1980 . Of this, about 81 percent, or 318 $\mathrm{Mgal} / \mathrm{d}$, was pumped from the volcanic-rock aquifers of the island, with $238 \mathrm{Mgal} / \mathrm{d}$ being pumped from the southern Oahu area alone. About 19 percent, or 76 $\mathrm{Mgal} / \mathrm{d}$, of the total from all sources was derived from water-development tunnels, flowing wells, and pumpage from aquifers in the caprock.

A predevelopment water budget was estimated for each of the ground-water flow systems of Oahu and for the island. Estimated mean annual ground-water recharge on Oahu is estimated to be about $792 \mathrm{Mgal} / \mathrm{d}$, representing about 40 percent of mean annual precipitation. About 16 percent of mean annual precipitation is lost to runoff and 44 percent is lost to evapotranspiration. Nearly these same percentages apply to the hydrologically important noncaprock areas of southern and northern Oahu.

Of the $521 \mathrm{Mgal} / \mathrm{d}$ of ground-water recharge to the noncaprock areas of southern and northern Oahu, about $199 \mathrm{Mgal} / \mathrm{d}$ was from the Schofield ground-water area and those parts of the Koolau and Waianae rift zones adjacent to the Schofield area. An estimated 111 $\mathrm{Mgal} / \mathrm{d}$ moves into the Schofield area as underflow from the Koolau rift zone, while about $9 \mathrm{Mgal} / \mathrm{d}$ moves as underflow from the Waianae rift zone. About $79 \mathrm{Mgal} / \mathrm{d}$ recharges the Schofield area directly. About $103 \mathrm{Mgal} / \mathrm{d}$ is estimated to move as underflow from the southern Schofield area into the Pearl Harbor and Ewa groundwater areas in southern Oahu; about $96 \mathrm{Mgal} / \mathrm{d}$ moves as underflow from the northern Schofield area into the Waialua ground-water area in northern Oahu.

Predevelopment ground-water recharge and groundwater underflow to the Pearl Harbor ground-water area are estimated to total about $261 \mathrm{Mgal} / \mathrm{d}$. This assumes that $103 \mathrm{Mgal} / \mathrm{d}$ from the southern Schofield area enters the Pearl Harbor area; some of this flows into the 
adjacent Ewa ground-water area, but probably less than $1 \mathrm{Mgal} / \mathrm{d}$. Recharge and underflow to the Ewa area is estimated to be about $9 \mathrm{Mgal} / \mathrm{d}$. Predevelopment recharge to the remaining areas of the southern Oahu flow system totals about $71 \mathrm{Mgal} / \mathrm{d}$.

Predevelopment recharge and underflow to the Waialua ground-water area in northern Oahu are estimated to total about $104 \mathrm{Mgal} / \mathrm{d}$, to the Kawailoa area about $62 \mathrm{Mgal} / \mathrm{d}$, and to the Mokuleia area about 14 $\mathrm{Mgal} / \mathrm{d}$.

Land-use changes affect the ground-water system by changing the magnitude and distribution of groundwater recharge. The major effect of land-use changes on ground-water recharge is from irrigated agriculture. Urbanization also leads to changes in the water budget and changes to ground-water recharge. Ground-water recharge to the noncaprock areas of the island increased to $824 \mathrm{Mgal} / \mathrm{d}$ in the mid-1980's. The increase of 54 $\mathrm{Mgal} / \mathrm{d}$ above predevelopment rates was estimated to have come as a result of land-use changes in southern and northern Oahu, largely urbanization and agriculture. Estimated recharge increased by $32 \mathrm{Mgal} / \mathrm{d}$ in southern Oahu and by $22 \mathrm{Mgal} / \mathrm{d}$ in northern Oahu. Of the estimated increase in southern Oahu, $15 \mathrm{Mgal} / \mathrm{d}$ was return flow from irrigated sugarcane and $18 \mathrm{Mgal} / \mathrm{d}$ was from nonirrigated pineapple (pineapple reduces natural evapotranspiration); there was a $1 \mathrm{Mgal} / \mathrm{d}$ decrease in recharge in areas that became urbanized. In northern Oahu, all the increase was return flow from irrigated sugarcane.

A conceptual model of the southern Oahu ground-water flow system was not altered significantly by the results of steady-state simulation of predevelopment and 1950's conditions. During the calibration process, it was determined that there was considerable anisotropy in aquifer hydraulic conductivity in the basalt aquifers. It also was determined that the magnitude and distribution of hydraulic conductivity of the caprock confining unit was not uniform and varied from one subarea to another. Finally, after considerable analysis, it was decided that the original estimate of irrigation return flow was too large. The initial steady-state simulation model assumed a uniform hydraulic conductivity for the basalt aquifers of $2,000 \mathrm{ft} / \mathrm{d}$. This value was changed so that a maximum hydraulic conductivity of $4,500 \mathrm{ft} / \mathrm{d}$ was assigned to a direction perpendicular to the Waianae crest for the Waianae volcanics and perpendicular to the Koolau crest for the Koolau Basalt; that is parallel to the direction of lava flow. A minimum hydraulic conductivity of $1,500 \mathrm{ft} / \mathrm{d}$ was assigned to the direction perpendicular to the direction of maximum hydraulic conductivity; or perpendicular to the direction of lava flow.

The original estimated irrigation-return flow for the period 1951-58 was about $107 \mathrm{Mgal} / \mathrm{d}$, of which about $87 \mathrm{Mgal} / \mathrm{d}$ was from furrow-irrigated sugarcane and the remainder from pineapple and other irrigation. The revised estimate is $40 \mathrm{Mgal} / \mathrm{d}$ of return flow from all sources. Of this total, about $35 \mathrm{Mgal} / \mathrm{d}$ is estimated to be from furrow-irrigated sugarcane.

Assumptions upon which the model is based are important to the understanding of the results of the analysis. Perhaps the most significant and limiting assumption is that the underlying freshwater-saltwater interface is sharp and well defined and that it responds instantly to changes in freshwater head. This assumption limits use of the model to simulations of long-term, steady-state conditions. Equilibration of the interface may take as long as 60 to 80 years following a change in pumping rate, although 80 to 90 percent of the equilibration probably will be achieved in about 20 years. The assumption of a sharp interface does not allow use of the model to predict the location of nonpotable saline water because the interface is, in reality, a transition zone of undetermined thickness. Proper determination of the effects of pumpage on the transition zone must be evaluated separately from the representations provided by this model.

Several issues remain unresolved or incompletely resolved. The direction of maximum hydraulic conductivity in the Pearl Harbor area warrants additional analysis. The data available for the simulation analysis, however, did not justify further pursuit of this issue. The reason for the overestimation of irrigation return flow is uncertain and was beyond the scope of the study. Resolution of this problem and a better estimate of the distribution of this component of recharge will help in developing a better definition of the distribution of hydraulic conductivity and direction of maximum hydraulic conductivity in the aquifer. The wedge geometry of the caprock was chosen to simulate increased resistance to freshwater discharge in the seaward direction. A caprock slab of rather uniform thickness with a decreasing hydraulic conductivity and increasing saltwater head in the seaward direction also would simulate the increased resistance to discharge. Determination of the most appropriate caprock configuration will require a more detailed analysis of the geohydrology of the caprock and underlying saprolite than was possible during this study. 


\section{REFERENCES CITED}

Bear, J., 1979, Hydraulics of groundwater: New York, McGraw-Hill, $569 \mathrm{p}$.

Blumenstock, D.I., and Price, S., 1967, Climates of the StatesHawaii: U.S. Department of Commerce, Climatography of the United States, no. 60-51, 27 p.

Burnham, W.L., Larson, S.P., and Cooper, H.H., Jr., 1977, Distribution of injected wastewater in the saline lava aquifer, WailukuKahului wastewater-treatment facility, Kahului, Maui, Hawaii: U.S. Geological Survey Open-File Report 77-469, 58 p.

Clague, D.A., and Dalrymple, G.B., 1987, The Hawaiian-Emperor volcanic chain. Part I. Geologic evolution, in Decker, R.W., and others, eds., Volcanism in Hawaii: U.S. Geological Survey Professional Paper 1350, v. 1, p. 5-54.

Cooper, H.H., Jr., 1959, A hypothesis concerning the dynamic balance of fresh water and salt water in a coastal aquifer: Journal of Geophysical Research, v. 64, no. 4, p. 461-467.

Dale, R.H., 1967, Land use and its effect on the basal water supply, Pearl Harbor area, Oahu, Hawaii, 1931-65: U.S. Geological Survey Hydrologic Investigations Atlas HA-267.

1974, Relationship of ground-water tides to ocean tides. A digital simulation model: University of Hawaii, Ph.D. dissertation, $150 \mathrm{p}$.

1978, A ground-water inventory of the Waialua basa-water body, island of Oahu, Hawaii: U.S. Geological Survey Open-File Report 78-24, $71 \mathrm{p}$.

Dale, R.H., and Takasaki, K.J., 1976, Probable effects of increasing pumpage from the Schofield ground-water body, island of Oahu, Hawaii: U.S. Geological Survey Water-Resources Investigations Report 76-47, $45 \mathrm{p}$.

Ewart, C.J., 1986, Oahu island Regional Aquifer-System study, Hawaii, in Sun, R.J., ed., Regional Aquifer-System Analysis program of the U. S. Geological Survey, Summary of projects, 1978-34: U.S. Geological Survey Circular 1002, p. 95-204.

Eyre, P.R., 1983, The effects of pumpage, irrigation return, and regional ground-water flow on the water quality at Waiawa water tunnel, Oahu, Hawaii: U.S. Geological Survey Water-Resources Investigations Report 83-4097, $44 \mathrm{p}$.

Eyre, P.R., Ewart, C., and Shade, P.J., 1986, Hydrology of the leeward aquifers, southeast Oahu, Hawaii: U.S. Geological Survey WaterResources Investigations Report 85-4270, 67 p.

Eyre, P.R., and Nichols, W.D., in press, Regional analysis of the Southern Oahu Ground-water flow system: U.S. Geological Survey Water-Resources Investigations Report 95-4256.

Ferris, J.G., Knowles, D.B., Brown, R.H., and Stallman, R.W., 1962, Theory of aquifer tests: U.S. Geological Survey Water-Supply Paper 1536-E, $174 \mathrm{p}$.

Freeze, R.A., and Cherry, J.A., 1979, Groundwater: Englewood Cliffs, New Jersey, Prentice-Hall, Inc., 604 p.

Giambelluca, T.W., 1983, Water balance of the Pearl Harbor-Honolulu basin, 1946-1975: University of Hawaii, Water Resources Research Center, Technical Report no. 151, 151 p.

1986, Land-use effects on the water balance of a tropical island: National Geological Society, National Geographic Research, v. 2, p. 125-151.

Giambelluca, T.W., Nullet, M.A., and Schroeder, T.A., 1986, Rainfall atlas of Hawaii: State of Hawaii, Department of Land and Natural Resources Report R76, 267 p.

Hantush, M.S., 1960, Modification of the theory of leaky aquifers: Journal of Geophysical Research, v. 65 , no. 11, p. 3,713-3,725.

Hawaii Department of Planning and Economic Development, 1977, The State of Hawaii data book, 1977: Department of Planning and Economic Development, $339 \mathrm{p}$.
1983, The State of Hawaii data book, 1983: Department of Planning and Economic Development, 663 p.

Hawaii Department of Planning and Research, 1962, Statistical abstract of Hawaii, 1962: Department of Planning and Research.

Hirashima, G.T., 1962, Effect of the Haiku tunnel on Kahaluu Stream, Oahu, Hawaii: U.S. Geological Survey Professional Paper 450C, p. C118-C120.

1971, Tunnels and dikes of the Koolau Range, Oahu, Hawaii, and their effect on storage depletion and movement of ground water: U.S. Geological Survey Water-Supply Paper 1999-M, $21 \mathrm{p}$.

Hitchcock, C.H., 1900, The geology of Oahu: Geological Society of America Bulletin, v. 11, no. 23.

Hunt, C.D., in press, Geohydrology of the Island of Oahu, Hawaii: U.S. Geological Survey Professional Paper 1412-B.

Hunt, C.D., Jr., Ewart, C.J., and Voss, C.I., 1988, Region 27, Hawaiian Islands, in Back, W., Rosenshein, J.S., Seaber, P.R., eds., Hydrogeology: Boulder, Colorado, Geological Society of America, The Geology of North America, v. O-2, p. 263-270.

Ishizaki, K., Burbank, N.C., Jr., and Lau, L.S., 1967, Effects of soluble organics on flow through thin cracks of basaltic lava: University of Hawaii, Water Resources Research Center Technical Report no. $16,56 \mathrm{p}$.

Jacob, C.E., 1946, Radial flow in a leaky artesian aquifer: American Geophysical Union Transactions, v. 27, no. 2, p 198-205.

Jorgensen, J., 1916, Development of water by tunneling in Oahu: City and county of Honolulu, Honolulu Water Commission report to the Honorable Mayor and Board of Supervisors, 1917, p. 92-97.

Khan, I.A., 1981, Wastewater disposal through a coastal aquifer: Water Resources Bulletin, v. 16, no. 4, p. 608-614.

Langenheim, V.A.M., and Clague, D.A., 1987, The Hawaiian-Emperor volcanic chain. Part II. Stratigraphic framework of volcanic rocks of the Hawaiian islands, in Decker, R.W., and others, eds., Volcanism in Hawaii: U.S. Geological Survey Professional Paper 1350 , v. 1, p. 55-84.

Lindgren, Waldemar, 1903, The water resources of Molokai, Hawaiian islands: U.S. Geological Survey Water-Supply Paper 77, 62 p.

Liu, C.C.K., Lau, L.S., and Mink, J.F., 1981, Numerical simulation of a thick freshwater lens-Pearl Harbor ground-water model: Water Resources Research Center, University of Hawaii, Technical Report, no. 139, 71 p.

1983, Ground-water model for a thick fresh-water lens: Groundwater, v. 21, no. 3, p. 293-300.

Macdonald, G.A., 1972, Volcanoes: Englewood Cliffs, N.J., PrenticeHall, 510 p.

Macdonald, G.A., Abbott, A.T., and Peterson, F.L., 1983, Volcanoes in the sea. The geology of Hawaii (2d ed.): Honolulu, University of Hawaii Press, 517 p.

Meinzer, O.E., 1930, Ground water in the Hawaiian islands, in Stearns, H.T., and Clark, W.O., eds., Geology and water resources of the Kau District, Hawaii: U.S. Geological Survey Water-Supply Paper 616, p. 1-28.

Mink, J.F., 1980, State of the ground-water resources of southern Oahu: Honolulu, City and County of Honolulu, Board of Water Supply, 83 p.

1981, DBCP and EDB in soil and water at Kunia, Oahu, Hawaii: Honolulu, Del Monte Corporation, $90 \mathrm{p}$.

Mink, J.F., and Lau, L.S., 1980, Hawaiian ground-water geology and hydrology, and early mathematical models: University of Hawaii, Water Resources Research Center Technical Memorandum Report no. 62, $74 \mathrm{p}$.

1990, Aquifer identification and classification for Oahuground-water protection strategy for Hawaii: University of Hawaii, Water Resources Research Center Technical Memorandum Report no. $179,28 \mathrm{p}$. 
Mink, J.F., and Sumida, S.T., 1984, Aquifer classification, State of Hawaii: University of Hawaii, Water Resources Research Center Technical Memorandum Report no. 75, 34 p.

Miyamoto, S.E., Miyaji, C.E., and Fukuda, L.L.K, 1986, Summary of available ground-water data for the island of Oahu, Hawaii: U.S. Geological Survey Open-File Report 86-233, 216 p.

Moore, J.G., 1987, Subsidence of the Hawaiian Ridge, in Decker, R.W., and others, eds., Volcanism in Hawaii: U.S. Geological Survey Professional Paper 1350, v. 1, p. 85-100.

Moore, J.G., and Campbell, J.F., 1987, Age of tilted reefs, Hawaii: Journal of Geophysical Research, v. 92, no. B3, p. 2,641-2,646.

Nakahara, R.H., 1980, Water use in Hawaii 1980: State of Hawaii, Department of Land and Natural Resources Report R71, 26 p.

Oberdorfer, J.A., and Peterson, F.L., 1985, Waste-water injection: Geochemical and biogeochemical clogging processes: Ground Water, v. 23, no. 6 , p. 753-761.

Palmer, H.S., 1927, The geology of the Honolulu artesian system, supplement to the report of the Honolulu Sewer and Water Commission: Honolulu, Mercantile Press, $68 \mathrm{p}$.

1946, The geology of the Honolulu ground-water supply: Honolulu, Board of Water Supply, 55 p.

Peterson, F.L., and Seghal, M.M., 1974, Determining porosity with neutron logs from Hawaiian basaltic aquifers: University of Hawaii, Water Resources Research Center Technical Report no. $80,37 \mathrm{p}$.

Rosenau, J.C., Lubke, E.R., and Nakahara, R.H., 1971, Water resources of north-central Oahu, Hawaii: U.S. Geological Survey Water-Supply Paper 1899-D, 40 p.

Schuyler, J.D., and Allardt, G.F., 1889, Report on the water supply for irrigation of the Honolulu and Kahuku Ranches: Oakland, Calif., Jordan and Arnold Printers, 32 p.

Shade, P.J., and Nichols, W.D., 1996, Water budget and the effects of land-use changes on ground-water recharge, Oahu, Hawaii: U.S. Geological Survey Professional Paper 1412-C, 38 p.

Sinton, J.M., 1986, Revision of stratigraphic nomenclature of Waianae Volcano, Oahu, Hawaii: U.S. Geologic Survey Bulletin 1775-A, p. A9-A15.

Soroos, R.L., 1973, Determination of hydraulic conductivity of some Oahu aquifers with step-drawdown data: University of Hawaii, Masters thesis, $47 \mathrm{p}$.

Soroos, R.L., and Ewart, C.J., 1979, Ground-water status report, Pearl Harbor area, 1978: U.S. Geological Survey Open-File Report 791542,3 sheets.

Souza, W.R., and Voss, C.I., 1987, Analysis of an anisotropic coastal aquifer system using variable-density flow and solute-transport simulation: Journal of Hydrology, v. 92, p. 17-41.

State of Hawaii Department of Agriculture, 1980, State Agriculture Plan: State of Hawaii Department of Agriculture, 153 p., 3 app.

Stearns, H.T., 1939, Geologic map and guide of island of Oahu, Hawaii: Hawaii Division of Hydrography Bulletin 2, 75 p. 1940 , Supplement to the geology and ground-water resources of the island of Oahu, Hawaii: Hawaii Division of Hydrography Bulletin 5, $164 \mathrm{p}$.

1946, Geology of the Hawaiian islands: Hawaii Division of Hydrography Bulletin 8, $112 \mathrm{p}$.

1978, Quaternary shorelines in the Hawaiian islands: Honolulu, Bishop Museum Press, Bulletin 237, 57 p. 1985, Geology of the State of Hawaii (2d ed.): Palo Alto, Calif., Pacific Books, $335 \mathrm{p}$.

Stearns, H.T., and Clark, W.O., 1930, Geology and water resources of the Kau District, Hawaii: U.S. Geological Survey Water-Supply Paper 616, 194 p.
Stearns, H.T., and Macdonald, G.A., 1940, Geologic map of the Waianae Range, in Stearns, H.T., ed., Supplement to the geology and ground-water resources of the island of Oahu, Hawaii: Hawaii Division of Hydrography Bulletin 5, 164 p.

Stearns, H.T., and Vaksvik, K.N., 1935, Geology and ground-water resources of the island of Oahu, Hawaii: Hawaii Division of Hydrography Bulletin 1, $479 \mathrm{p}$.

1938, Records of the drilled wells on the island of Oahu, Hawaii: Hawaii Division of Hydrography Bulletin 4, $213 \mathrm{p}$.

Sun, R.J., ed., 1986, Regional Aquifer-System Analysis program of the U.S. Geological Survey, summary of projects, 1978-84: U.S. Geological Survey Circular 1002, $264 \mathrm{p}$.

Swanson, R.W., Hubert, M.L., Luttrell, G.W., and Jussen, V.M., 1981, Geologic names of the United States through 1975: U.S. Geological Survey Bulletin 1535, 643 p.

Takasaki, K.J., 1971, Ground water in the Waianae District, Oahu, Hawaii: U.S. Geological Survey Hydrologic Investigations Atlas HA-358, 2 sheets.

Takasaki, K.J., Hirashima, G.T., and Lubke, E.R., 1969, Water resources of windward Oahu, Hawaii: U.S. Geological Survey Water-Supply Paper 1894, 119 p.

Takasaki, K.J., and Mink, J.F., 1982, Water resources of southeastern Oahu, Hawaii: U.S. Geological Survey Water-Resources Investigations $82-628,82 \mathrm{p}$.

1985, Evaluation of major dike-impounded ground-water reservoirs, island of Oahu: U.S. Geological Survey Water-Supply Paper 2217, $77 \mathrm{p}$.

Takasaki, K.J., and Valenciano, S., 1969, Water in the Kahuku area, Oahu, Hawaii: U.S. Geological Survey Water-Supply Paper 1874, $59 \mathrm{p}$.

Theis, C.V., 1935, Relation between the lowering of the piezometric surface and the rate and duration of discharge of a well using ground-water storage: American Geophysical Union Transactions, pt. 2 , p. 519-524.

Thiem, G., 1906, Hydrologische methoden: Leipzig, Germany, J.M. Gebhart, $56 \mathrm{p}$

Todd, D.K., and Meyer, C.F., 1971, Hydrology and geology of the Honolulu aquifer: Proceedings of the American Society of Civil Engineers, Journal of the Hydraulics Division, v. 97, no. HY2, p. 233-256.

Trescott, P.C., Pinder, G.F., and Larson, S.P., 1976, Finite-difference model for aquifer simulation in two dimensions with results of numerical experiments: U. S. Geological Survey Techniques of Water-Resources Investigations, book 7, chap. C1, 116 p.

U.S. Department of Commerce, 1901, Twelfth census of the United States, 1900: Bureau of the Census, v. I, p. 47.

1913, Thirteenth census of the United States, 1910: Bureau of the Census, v. 3 , p. 1,157 .

1921, Fourteenth census of the United States taken in the year 1920: Bureau of the Census, v. I, p. 682

- - 1953, A report of the seventeenth decennial census of the United States, Census of population, 1950: Bureau of the Census, parts $51-54$, p. $52-5,52-6$.

1977, County and city data book, 1977: Bureau of the Census, 1983, County and city data book, 1983: Bureau of the Census, 1992, Census of population and housing, population and housing characteristics for Congressional Districts of the 103rd Congress-Hawaii: Bureau of the Census, report CPH 4-13, p. 2.

University of Hawaii Department of Geography, 1983, Atlas of Hawaii (2d ed.): Honolulu, University of Hawaii Press, 238 p.

Visher, F.N., and Mink, J.F., 1964, Ground-water resources in southern Oahu, Hawaii: U.S. Geological Survey Water-Supply Paper 1778, 133 p. 
Voss, C.I., 1984, AQUIFEM-SALT, A finite-element model for aquifers containing a seawater interface: U.S. Geological Survey WaterResources Investigations Report 84-4263, 37 p.

Walker, G.P.L., 1986, Koolau dike complex, Oahu: Intensity and origin of a sheeted-dike complex high in a Hawaiian volcanic edifice: Geology, v. 14, p. 310-313.

1987, The dike complex of Koolau Volcano, Oahu: Internal structure of a Hawaiian rift zone, in Decker, R.W., and others, eds., Volcanism in Hawaii: U.S. Geological Survey Professional Paper 1350, v. 2, p. 961-993.

Wentworth, C.K., 1926, Pyroclastic geology of Oahu: B.P. Bishop Museum, Bulletin 30, 121 p.

1938, Geology and ground-water resources of the PaloloWaialae District: Honolulu, City and County of Honolulu, Unpublished manuscript in files of the Board of Water Supply, $274 \mathrm{p}$.

1939, The specific gravity of sea water and the GhybenHerzberg ratio at Honolulu: Honolulu, University of Hawaii Bulletin, v. 18 , no. 8,24 p.

1942, Storage consequences of the Ghyben-Herzberg Theory: American Geophysical Union Transactions, p. 683-693.

1945 , Geology and ground-water resources of the Pearl Harbor District: Honolulu, City and County of Honolulu, Unpublished manuscript in files of the Board of Water Supply, 156 p. and appendices.
1951, Geology and ground-water resources of Honolulu-Pearl Harbor area, Oahu, Hawaii: Honolulu, City and County of Honolulu, Board of Water Supply, $111 \mathrm{p}$.

Wentworth, C.K., and Winchell, Horace, 1947, Koolau basalt series, Oahu, Hawaii: Geological Society of America Bulletin, v. 58, p. 49-78.

White, W.B., 1969, Conceptual models for carbonate aquifers: Ground Water, v. 7, no 3, p. 15-21.

Williams, J.A., and Liu, T.C., 1975, Response to tides of coastal aquifers: Analog simulation vs. field observation: University of Hawaii, Water Resources Research Center Technical Report no. $86,67 \mathrm{p}$.

Williams, J.A., and Soroos, R.L., 1973, Evaluation of methods of pumping test analyses for application to Hawaiian aquifers: University of Hawaii, Water Resources Research Center Technical Report no. 70, 159 p.

Winchell, Horace, 1947, Honolulu Series, Oahu, Hawaii: Geological Society of America Bulletin, v. 58, p. 1-48.

Wilson, J.T., 1963, A possible origin of the Hawaiian Islands: Canadian Journal of Physics, v. 41, p. 863-870.

Zones, C.P., 1963, Preliminary report on the ground-water resources of the Waianae area, Oahu, Hawaii: State of Hawaii, Department of Land and Natural Resources Circular C 16, 12 p. 
APPENDIX

Annual mean daily ground-water pumpage from major ground-water areas,

island of Oahu, Hawaii, 1901-85

[All values in million gallons per day; -, indicates either no pumpage or data not available]

\begin{tabular}{|c|c|c|c|c|c|c|c|c|}
\hline Year & $\begin{array}{c}\text { Waianae } \\
\text { rift }\end{array}$ & Northern & $\begin{array}{c}\text { Schofield } \\
\text { area }\end{array}$ & Southern & Southeastern & Koolau rift & Kahuku & Total \\
\hline 1901 & - & - & - & 18.1 & - & - & - & 18.1 \\
\hline 1902 & - & - & - & 35.8 & - & - & - & 35.8 \\
\hline 1903 & - & - & - & 47.3 & - & - & - & 47.3 \\
\hline 1904 & - & - & - & 42.7 & - & - & 8.9 & 51.6 \\
\hline 1905 & - & - & - & 103.3 & - & - & 13.6 & 116.9 \\
\hline 1906 & - & - & - & 100.4 & - & - & 12.7 & 113.0 \\
\hline 1907 & - & - & - & 90.3 & - & - & 9.9 & 100.2 \\
\hline 1908 & - & - & - & 114.9 & - & - & 12.8 & 127.6 \\
\hline 1909 & - & - & - & 115.5 & - & - & 9.9 & 125.4 \\
\hline 1910 & - & - & - & 142.5 & - & - & 10.9 & 153.4 \\
\hline 1911 & - & - & - & 147.7 & - & - & 10.2 & 157.9 \\
\hline 1912 & - & - & - & 172.0 & - & - & 14.3 & 186.3 \\
\hline 1913 & - & - & - & 157.4 & - & - & 11.1 & 168.5 \\
\hline 1914 & - & 23.2 & - & 151.1 & - & - & 10.3 & 184.6 \\
\hline 1915 & - & 30.3 & - & 167.7 & - & - & 10.3 & 208.3 \\
\hline 1916 & - & 7.7 & - & 121.8 & - & - & 10.5 & 140.0 \\
\hline 1917 & - & - & - & 91.8 & - & - & 9.4 & 101.2 \\
\hline 1918 & - & - & - & 86.7 & - & - & 8.7 & 95.4 \\
\hline 1919 & - & - & - & 185.2 & - & - & 14.6 & 199.8 \\
\hline 1920 & - & - & - & 143.2 & - & - & 12.9 & 156.1 \\
\hline 1921 & - & - & - & 128.2 & - & - & 15.1 & 143.3 \\
\hline 1922 & - & - & - & 165.0 & - & - & 13.3 & 178.3 \\
\hline 1923 & - & - & - & 157.8 & - & - & 11.2 & 169.0 \\
\hline 1924 & - & 35.2 & - & 203.7 & - & - & - & 238.9 \\
\hline 1925 & - & 28.8 & - & 210.8 & - & - & - & 239.6 \\
\hline 1926 & - & 44.8 & - & 198.5 & - & 0.1 & 14.4 & 257.8 \\
\hline 1927 & - & 27.3 & - & 168.2 & - & 0.2 & 7.8 & 203.5 \\
\hline 1928 & - & 37.0 & - & 197.6 & - & 0.3 & 11.1 & 246.0 \\
\hline 1929 & - & 50.4 & - & 204.2 & - & 0.4 & 12.6 & 267.6 \\
\hline 1930 & - & 29.8 & - & 176.6 & 0.3 & 0.6 & 14.4 & 221.7 \\
\hline 1931 & - & 49.4 & - & 213.6 & 0.4 & 0.7 & 17.2 & 281.3 \\
\hline 1932 & 0.4 & 26.3 & - & 186.6 & 0.3 & 0.7 & 18.3 & 232.6 \\
\hline 1933 & 5.3 & 53.2 & - & 203.9 & 0.3 & 0.8 & 21.8 & 285.3 \\
\hline 1934 & 5.2 & 47.8 & - & 182.3 & 0.4 & 0.8 & 15.8 & 252.3 \\
\hline 1935 & 4.7 & 39.4 & - & 176.3 & 0.4 & 0.9 & 17.9 & 239.6 \\
\hline 1936 & 4.9 & 35.5 & - & 173.7 & 0.4 & 0.7 & 16.6 & 231.8 \\
\hline 1937 & 5.4 & 39.8 & - & 171.9 & 0.7 & 0.9 & 16.7 & 235.4 \\
\hline 1938 & 5.8 & 39.7 & 0.8 & 181.8 & 1.1 & 1.0 & 17.0 & 247.2 \\
\hline 1939 & 5.4 & 37.9 & 3.4 & 180.4 & 1.0 & 0.8 & 20.7 & 249.6 \\
\hline 1940 & 2.9 & 48.7 & 3.4 & 200.6 & 1.1 & - & 24.4 & 281.1 \\
\hline 1941 & 2.9 & 53.5 & 4.0 & 228.3 & 1.2 & - & 30.4 & 320.3 \\
\hline 1942 & 2.7 & 36.9 & 4.1 & 216.8 & 1.4 & 0.1 & 22.4 & 284.4 \\
\hline 1943 & 2.9 & 42.6 & 6.2 & 241.9 & 1.4 & 0.1 & 25.8 & 320.9 \\
\hline 1944 & 3.3 & 58.5 & 6.7 & 261.2 & 1.0 & 4.9 & 32.5 & 368.1 \\
\hline 1945 & 2.7 & 60.1 & 7.6 & 254.5 & 1.0 & 4.2 & 35.1 & 365.2 \\
\hline 1946 & 2.7 & 41.9 & 5.7 & 203.4 & 1.0 & 3.1 & 35.4 & 293.2 \\
\hline 1947 & 2.0 & 43.3 & 4.6 & 203.0 & 0.9 & 3.5 & 45.2 & 302.5 \\
\hline 1948 & 3.3 & 33.5 & 4.0 & 190.2 & 0.9 & 3,8 & 27.1 & 262.8 \\
\hline 1949 & 4.0 & 54.6 & 4.8 & 205.6 & 0.9 & 4.0 & 29.8 & 303.7 \\
\hline 1950 & 5.2 & 36.4 & 4.4 & 195.7 & 0.9 & 4.0 & 26.9 & 273.5 \\
\hline 1951 & 6.7 & 47.3 & 4.1 & 191.1 & 0.9 & 3.4 & 27.4 & 280.9 \\
\hline 1952 & 5.7 & 40.3 & 4.5 & 222.6 & 0.9 & 4.7 & 30.5 & 309.2 \\
\hline 1953 & 4.3 & 56.4 & 3.8 & 237.6 & 1.0 & 5.3 & 40.9 & 349.3 \\
\hline
\end{tabular}


Annual mean daily ground-water pumpage from major ground-water areas, island of Oahu, Hawaii, 1901-85-Continued

[All values in million gallons per day; - , indicates either no pumpage or data not available]

\begin{tabular}{|c|c|c|c|c|c|c|c|c|}
\hline Year & $\begin{array}{c}\text { Waianae } \\
\text { rift }\end{array}$ & Northern & $\begin{array}{c}\text { Schofield } \\
\text { area }\end{array}$ & Southern & Southeastern & Koolau rift & Kahuku & Total \\
\hline 1954 & 4.6 & 35.5 & 3.6 & 201.4 & 0.9 & 4.7 & 27.7 & 278.4 \\
\hline 1955 & 5.2 & 40.0 & 4.6 & 187.0 & 0.9 & 5.2 & 29.9 & 272.8 \\
\hline 1956 & 5.3 & 30.9 & 5.0 & 196.4 & 0.9 & 6.1 & 26.7 & 271.3 \\
\hline 1957 & 5.2 & 49.9 & 5.1 & 219.6 & 0.5 & 5.9 & 30.1 & 316.3 \\
\hline 1958 & 4.4 & 25.5 & 4.9 & 175.2 & 0.6 & 7.1 & 18.5 & 236.2 \\
\hline 1959 & 3.6 & 46.7 & 5.6 & 225.7 & 0.4 & 28.4 & 28.3 & 338.7 \\
\hline 1960 & 4.0 & 40.6 & 6.1 & 235.5 & 0.7 & 23.4 & 25.5 & 335.8 \\
\hline 1961 & 4.2 & 44.8 & 6.5 & 230.5 & 0.6 & 9.5 & 28.7 & 324.8 \\
\hline 1962 & 4.2 & 46.4 & 7.0 & 237.7 & 0.7 & 9.9 & 31.3 & 337.2 \\
\hline 1963 & 4.7 & 30.2 & 8.5 & 218.8 & 0.7 & 10.2 & 27.6 & 300.7 \\
\hline 1964 & 4.7 & 45.8 & 8.9 & 260.2 & 0.7 & 10.8 & 30.7 & 361.8 \\
\hline 1965 & 4.4 & 33.7 & 8.9 & 236.2 & 0.7 & 10.7 & 28.3 & 322.9 \\
\hline 1966 & 4.6 & 49.7 & 7.7 & 268.5 & 0.8 & 12.2 & 23.9 & 367.4 \\
\hline 1967 & 4.5 & 50.2 & 7.8 & 243.5 & 0.8 & 12.0 & 20.3 & 339.1 \\
\hline 1968 & 4.7 & 57.6 & 9.0 & 248.3 & 0.8 & 13.8 & 24.5 & 358.7 \\
\hline 1969 & 3.7 & 51.0 & 9.6 & 270.2 & 0.8 & 13.0 & 28.6 & 376.9 \\
\hline 1970 & 3.9 & 63.8 & 10.6 & 290.1 & 0.7 & 11.3 & 32.8 & 413.2 \\
\hline 1971 & 3.4 & 62.4 & 10.0 & 273.1 & 0.9 & 11.8 & 15.0 & 376.6 \\
\hline 1972 & 3.5 & 62.3 & 10.7 & 268.6 & 1.1 & 11.8 & 6.1 & 364.0 \\
\hline 1973 & 3.5 & 60.2 & 11.3 & 279.6 & 1.2 & 11.1 & 7.0 & 373.9 \\
\hline 1974 & 3.8 & 46.2 & 12.2 & 236.5 & 1.1 & 10.8 & 6.5 & 317.1 \\
\hline 1975 & 4.1 & 60.7 & 15.8 & 262.9 & 1.1 & 14.6 & 5.9 & 365.1 \\
\hline 1976 & 3.8 & 59.7 & 17.3 & 282.3 & 1.3 & 13.9 & 5.9 & 384.2 \\
\hline 1977 & 3.7 & 60.3 & 15.5 & 288.3 & 1.1 & 12.9 & 6.8 & 388.6 \\
\hline 1978 & 3.4 & 52.6 & 17.7 & 264.6 & 1.0 & 13.5 & 4.4 & 357.2 \\
\hline 1979 & 4.3 & 60.3 & 20.6 & 256.5 & 1.0 & 14.6 & 4.1 & 361.4 \\
\hline 1980 & 5.1 & 37.7 & 15.8 & 238.1 & 1.1 & 14.7 & 6.2 & 318.7 \\
\hline 1981 & 4.9 & 54.9 & 17.7 & 266.0 & 1.0 & 15.1 & 4.3 & 363.9 \\
\hline 1982 & 4.3 & 30.8 & 13.3 & 205.3 & 0.8 & 15.4 & 2.5 & 272.4 \\
\hline 1983 & 5.3 & 53.4 & 16.6 & 233.2 & 1.1 & 16.4 & 5.3 & 331.3 \\
\hline 1984 & 0.3 & 54.9 & 11.0 & 92.5 & - & 0.8 & - & 159.5 \\
\hline 1985 & 0.2 & 45.1 & 9.6 & 159.0 & 0.5 & 0.8 & - & 215.2 \\
\hline
\end{tabular}




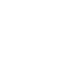

(2)

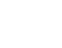
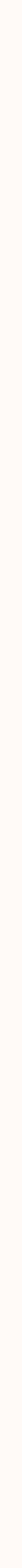
. 


\section{SELECTED SERIES OF U.S. GEOLOGICAL SURVEY PUBLICATIONS}

\section{Periodical}

Preliminary Determination of Epicenters (issued monthly)

\section{Technical Books and Reports}

Professional Papers are mainly comprehensive scientific reports of wide and lasting interest and importance to professional scientists and engineers. Included are reports on the results of resource studies and of topographic, hydrologic, and geologic investigations. They also include collections of related papers addressing different aspects of a single scientific type.

Bulletins contain significant data and interpretations that are of lasting scientific interest but are generally more limited in scope or geographic coverage than Professional Papers. They include the results of resource studies and of geologic and topographic investigations, as well as collections of short papers related to a specific topic.

Water-Supply Papers are comprehensive reports that present significant interpretive results of hydrologic investigations of wide interest to professional geologists, hydrologists, and engineers. The series covers investigations in all phases of hydrology, including hydrogeology, availability of water, quality of water, and use of water.

Circulars present administrative information or important scientific information of wide popular interest in a format designed for distribution at no cost to the public. Information is usually of short-term interest.

Water-Resources Investigations Reports are papers of an interpretive nature made available to the public outside the formal USGS publications series. Copies are reproduced on request, unlike formal USGS publications, and they also are available for public inspection at depositories indicted in USGS catalogs.

Open-File Reports include unpublished manuscript reports, maps, and other material that are made available for public consultation at depositories. They are a nonpermanent form of publication that may be cited in other publications as sources of information.

\section{Maps}

Geologic Quadrangle Maps are multicolor geologic maps on topographic bases in 7.5- or 15-minute quadrangle formats (scales mainly $1: 24,000$ or 1:62,500) showing bedrock, surficial, or engineering geology. Maps generally include brief texts; some maps include structure and columnar sections only.

Geophysical Investigations Maps are on topographic or planimetric bases at various scales; they show results of surveys using geophysical techniques, such as gravity, magnetic, seismic, or radioactivity, which reflect subsurface structures that are of economic or geologic significance. Many maps include correlations with the geology.

Miscellaneous Investigations Series Maps are on planimetric or topographic bases of regular and irregular areas at various scales; they present a wide variety of format and subject matter. The series also includes 7.5-minute quadrangle photogeologic maps on planimetric bases that show geology as interpreted from aerial photographs. Series also includes maps of Mars and the Moon.
Coal Investigations Maps are geologic maps on topographic or planimetric bases at various scales showing bedrock or surficial geology, stratigraphy, and structural relations in certain coal-resource areas.

Oil and Gas Investigations Charts show stratigraphic information for certain oils and gas fields and other areas having petroleum potential.

Miscellaneous Field Studies Maps are multicolor or blackand-white maps on topographic or planimetric bases for quadrangle or irregular areas at various scales. Pre-1971 maps show bedrock geology in relation to specific mining or mineral-deposit problems; post-1971 maps are primarily black-and-white maps on various subjects such as environmental studies or wilderness mineral investigations.

Hydrologic Investigations Atlases are multicolored or blackand-white maps on topographic or planimetric bases presenting a wide range of geohydrologic data of both regular and irregular areas; principal scale is 1:24,000, and regional studies are at $1: 250,000$ scale or smaller.

\section{Catalogs}

Permanent catalogs, as well as some others, giving comprehensive listings of U.S. Geological Survey publications are available under the conditions indicated below from the U.S. Geological Survey, Information Services, Box 25286, Federal Center, Denver, CO) 80225. (See latest Price and Availability List.)

"Publications of the Geological Survey, 1879-1961" may be purchased by mail and over the counter in paperback book form and as a set of microfiche.

"Publications of the Geological Survey, 1962-1970" may be purchased by mail and over the counter in paperback book form and as a set of microfiche.

"Publications of the U.S. Geological Survey, 1979-1981" may be purchased by mail and over the counter in paperback book form (two volumes, publications listing and index) and as a set of microfiche.

Supplements for 1982, 1983, 1984, 1985, 1986, and for subsequent years since the last permanent catalog may be purchased by mail and over the counter in paperback book form.

State catalogs, "List of U.S. Geological Survey Geologic and Water-Supply Reports and Maps for (State)" may be purchased by mail and over the counter in paperback booklet form only.

"Price and Availability List of U.S. Geological Survey Publications," issued annually, is available free of charge in paperback booklet form only.

Selected copies of a monthly catalog, "New Publications of the U.S. Geological Survey," are available free of charge by mail or may be obtained over the counter in paperback booklet form only. Those wishing a free subscription to the monthly catalog "New Publications of the U.S. Geological Survey" should write to the U.S. Geological Survey, 582 National Center, Reston, VA 20192.

Note.-Prices of Government publications listed in older catalogs, announcements, and publications may be incorrect. Therefore, the prices charged may differ from the prices in catalogs, announcements, and publications. 


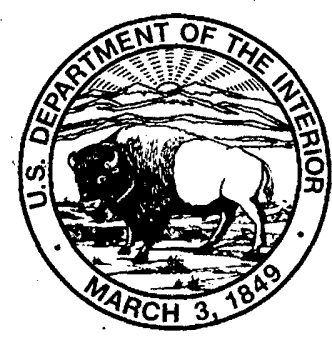

ISBN 0-60?-86101-0 